Florida International University

FIU Digital Commons

FIU Electronic Theses and Dissertations

University Graduate School

7-5-2016

\title{
The Effect of Social Capital on Organizational Performance in Different Cultures: A Cross- National Comparison of the United States and South Korea
}

Jung Hyun Song

Florida International University, jsong003@fiu.edu

DOI: $10.25148 /$ etd.FIDC000712

Follow this and additional works at: https://digitalcommons.fiu.edu/etd

Part of the Public Administration Commons

\section{Recommended Citation}

Song, Jung Hyun, "The Effect of Social Capital on Organizational Performance in Different Cultures: A Cross-National Comparison of the United States and South Korea" (2016). FIU Electronic Theses and Dissertations. 2613.

https://digitalcommons.fiu.edu/etd/2613 


\section{FLORIDA INTERNATIONAL UNIVERSITY}

Miami, Florida

\section{THE EFFECT OF SOCIAL CAPITAL ON ORGANIZATIONAL PERFORMANCE IN DIFFERENT CULTURES: A CROSS-NATIONAL COMPARISON OF THE UNITED STATES AND SOUTH KOREA}

A dissertation submitted in partial fulfillment of the requirements for the degree of DOCTOR OF PHILOSOPHY in

PUBLIC AFFAIRS

by

Jung Hyun Song 2016 
To: Dean John F. Stack

Steven J. Green School of International and Public Affairs

This dissertation, written by Jung Hyun Song, and entitled The Effect of Social Capital on Organizational Performance in Different Cultures: A Cross-National Comparison of the United States and South Korea, having been approved with respect to style and intellectual content, is referred to you for judgment.

We have read this dissertation and recommend that it be approved.

N. Emel Ganapati

Milena Neshkova

Allan Rosenbaum

Richard Tardanico

Meredith Newman, Major Professor

Date of Defense: July 5, 2016

The dissertation of Jung Hyun Song is approved.

Dean John F. Stack

Steven J. Green School of International and Public Affairs

Andres G. Gil

Vice President for Research and Economic Development and Dean of the University Graduate School

Florida International University, 2016 
(C) Copyright 2016 by Jung Hyun Song

All rights reserved. 


\section{DEDICATION}

I dedicate this dissertation to my family. Without their patience, understanding, support, and most of all love, the completion of this work would not have been possible. 


\section{ACKNOWLEDGMENTS}

I wish to thank the members of my dissertation committee for their support, assistance, patience, and kindness. I would like to express my sincere appreciation to the many people who provided support and assistance for the completion of my dissertation. First and foremost, I have to express my deep appreciation to my major Professor, Dr. Newman. This dissertation would not be possible without her supportive guidance and advice and continuous encouragement despite her busy daily schedules.

I also would like to thank my committee members, Dr. Allan Rosenbaum, Dr. Emel Ganapati, Dr. Millena Neshkova, and Dr. Richard Tardanico. It is my honor to have wonderful committee members. They provided continuous assistance and support toward my doctoral work. Their suggestions and comments were important for my research. I also extend my appreciation to Dr. Sukumar Ganapati. His consideration and encouragement enabled me to complete this dissertation. Again, I will forever be appreciative of the support of my committee: Dr. Meredith Newman, Committee Chair, Dr. Allan Rosenbaum, Dr. Emel Ganapati, Dr. Millena Neshkova, and Dr. Richard Tardanico.

I also would like to thank many people who helped me collect data. Dr. Carol Ebdon at the University of Nebraska Omaha. She emailed each department director to introduce me and my research. Her initial introduction helped me contact the directors and collect data. I want to express my appreciation to the city of Omaha and each department's directors who allowed me to conduct my research at their organization. For the data for Wonju city, I would like to thank Dr. Eungmann Kang who is the director of 
Park Department. He helped me distribute and collect survey questionnaires. Thanks to him, this study achieved a high response rate from Wonju city.

Finally, I would like to give great respects and special tanks to my family for all their moral support, love, patience, and belief in me. Also, I want to express my appreciation to Mrs. Judy Rosenbaum. She has been just like my mother in America and helped me live in the United States. I also would like to thank my former advisor in Korea, Dr. Taeryong Kim. He encouraged me to study abroad and always encouraged me to work hard. I am eternally grateful for everything you have taught me about public administration, about life, and about myself. 


\begin{abstract}
OF THE DISSERTATION
THE EFFECT OF SOCIAL CAPITAL ON ORGANIZATIONAL PERFORMANCE IN DIFFERENT CULTURES: A CROSS-NATIONAL COMPARISON OF THE UNITED STATES AND SOUTH KOREA
\end{abstract}

by

Jung Hyun Song

Florida International University, 2016

Miami, Florida

Professor Meredith Newman, Major Professor

The main purpose of this study is to analyze the effects of social capital on organizational performance of local government and whether the effect varies across national cultures. The study hypothesized that organizational level social capital in a public sector organization has a positive influence on organizational performance. To investigate the relationship, surveys were sent to public officials of local government organizations in the city of Omaha in the United States and Wonju city in South Korea. Based on Hofstede's definition of national culture, these two countries contrast strongly on important cultural characteristics. The two cities were selected as typical representatives of each country. Social capital was operationalized as structural, relational, and cognitive, and organizational performance was measured in terms of efficiency, effectiveness, responsiveness, and equity.

The surveys were distributed to public officials working in various city departments. The departments were chosen to represent the three main policy types (as defined by Lowi): regulatory policies, distributive policies, and redistributive 
policies. Out of 407 surveys sent, 294 usable and valid responses were received. The data were analyzed using SPSS computer software and included descriptive statistics, ANOVA, Pearson's simple correlation, t-test, factor analysis, linear regression analysis, dummy regression analysis, and moderator regression.

The results showed that organizations with higher levels of structural, relational, and cognitive social capital achieve higher levels of organizational performance. However, the effect of social capital in a public sector organization on organizational performance did not differ across cultures. Rather, within a given culture, the relationship varied by policy type. The findings provide some practical guidelines to government leaders on how to increase social capital to enhance organizational performance. By integrating public organizational theories with social capital literature, this study suggests the determinants of public sector performance. 


\section{TABLE OF CONTENTS}

CHAPTER

PAGE

CHAPTER 1: INTRODUCTION ...............................................

Motivation of the Study ..................................................

Statement of Purpose.................................................. 4

Significance of the Study.................................................

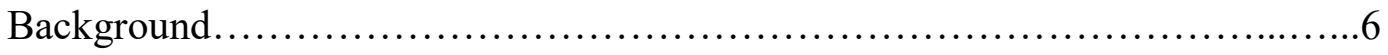

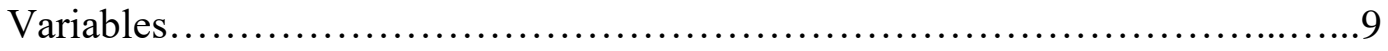

Methods, Data Collection, and Sample.....................................11

Overview of the Study............................................13

CHAPTER 2: LITERATURE REVIEW AND HYPOTHESES....................... 14

Social Capital......................................................... 14

Introduction................................................... 14

Background of Social Capital.......................................22

Academic Origin of Social Capital..............................22

Formation Background of Social Capital...........................24

Contents and Features of Social Capital...............................28

Dimensions of Social Capital.................................28

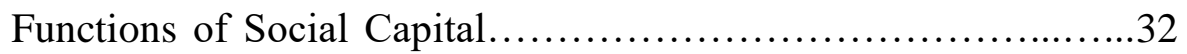

Relevance of Social Capital............................................... 34

Criticism of Social Capital.......................................34

Applicability of Social Capital...................................35

Organizational Performance............................................. 35

Introduction..................................................... 35

Efficiency....................................................... 40

Effectiveness................................................40

Responsiveness.................................................... 42

Equity....................................................... 43

Social Capital and Organizational Performance..............................45

Structural Social Capital and Organizational Performance..................48

Relational Social Capital and Organizational Performance.................44

Cognitive Social Capital and Organizational Performance...................51

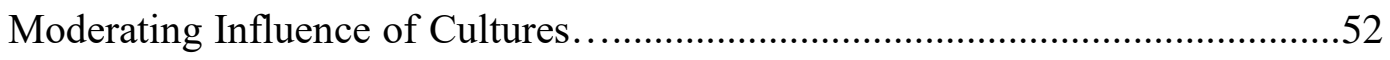

Hofstede's Dimensions of Culture ..................................55

Power Distance...........................................57

Uncertainty Avoidance........................................58

Individualism/Collectivism.................................58 
Masculinity/Femininity or Career Success and Quality of Life..........59

Long-term Orientation.....................................60

Agency Type.........................................................61

Regulatory Agencies...............................................62

Distributive Agencies............................................62

Redistributive Agencies..........................................66

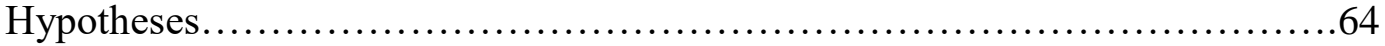

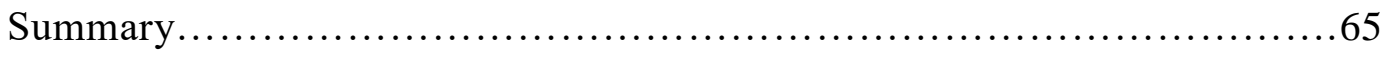

CHAPTER 3: RESEARCH METHODOLOGY .................................66

Analysis Model ......................................................66

Measuring Social Capital...............................................66

Measuring Organizational Performance...................................68

Measuring Culture......................................................70

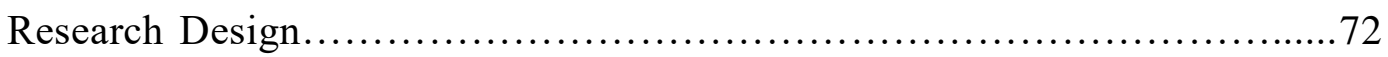

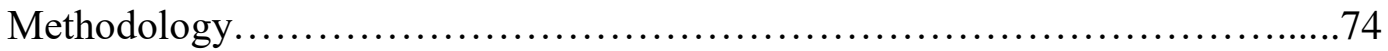

Unit of Analysis...................................................... 74

Sample and Data Collection.........................................74

Country Selection.........................................75

City Selection........................................... 75

Department Selection.......................................77

Data Collection Process.........................................80

Survey Instrument Development..................................8 82

Statistical Analysis Methods...............................................84

Summary......................................................... 86

CHAPTER 4: RESULTS AND FINDINGS ...................................... 87

South Korea ......................................................... 87

Sample Characteristics............................................87

Factor Analysis and Reliability Analysis.............................90

Descriptive Statistics...................................................93

Correlation Analysis.............................................95

Regression Analysis................................................. 98

The United States..................................................... 104

Sample Characteristics..............................................104

Factor Analysis and Reliability Analysis..............................105

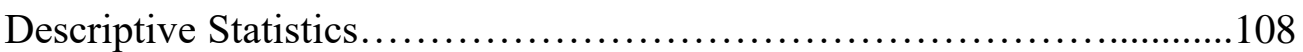

Correlation Analysis.................................................110

Regression Analysis..............................................113 
Comparative Analysis (South Korea and the United States)...................118

Sample Characteristics............................................118

Factor Analysis and Reliability Analysis.............................120

Descriptive Statistics................................................123

Correlation Analysis.............................................. 124

Regression Analysis..............................................129

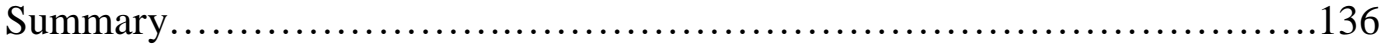

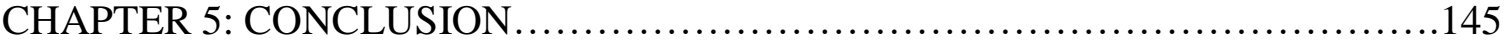

Summary of the Study............................................ 145

Policy Implications..................................................... 147

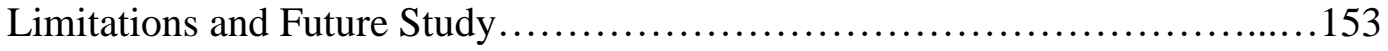

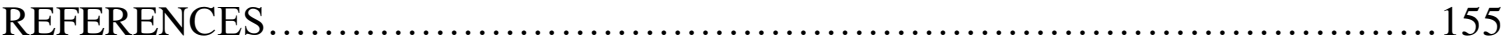

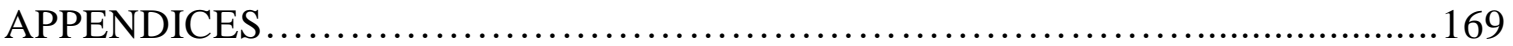

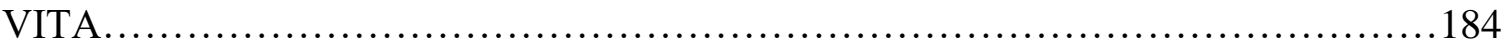




\section{LIST OF TABLES}

TABLE

PAGE

Table 1: Concepts and Components of Social Capital.................................... 18

Table 2: Summary of the Components of Social Capital by Scholars....................20

Table 3: Factors of Organizational Performance provided by scholars...................39

Table 4: Definitions of Organizational Effectiveness.............................41

Table 5: Values of Hofstede's Cultural Indices for the United States and South Korea....54

Table 6: Hofstede's Cultural Dimensions Defined...............................56

Table 7: Measurement Items of Social Capital..................................68

Table 8: Measurement Items of Organizational Performance.........................69

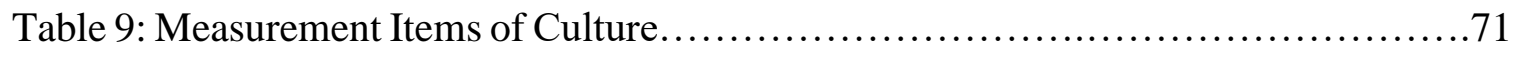

Table 10: Factors through Factor Analysis and Measurement Index....................73

Table 11: City Selection (South Korea) ........................................ 76

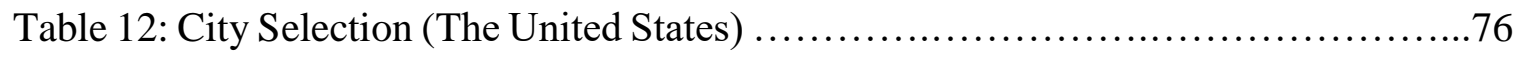

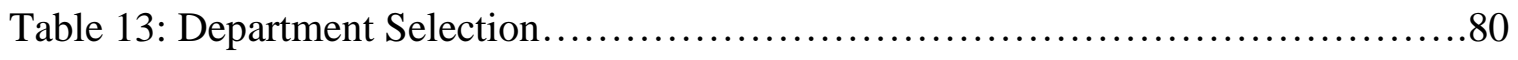

Table 14: Survey Distribution............................................ 82

Table 15: Survey Items per Variables......................................83

Table 16: Survey Distribution and Response (South Korea) .........................88

Table 17: Descriptive Statistics of Survey Respondents (South Korea) .................89

Table 18: Factor Analysis and Reliability Analysis (South Korea) .................... 91

Table 19: KMO and Bartlett's Test (South Korea) .............................93

Table 20: Goodness-of-Test (South Korea) ..................................... 93

Table 21: Mean and Standard Deviation by Factors (South Korea) ...................94 
Table 22: Mean and Standard Deviation by Variables (South Korea)

Table 23: Correlations of Culture and Social Capital and

Organizational Performance (South Korea) ........................................96

Table 24: t-test of Gender and Factors (South Korea) ............................... 97

Table 25: Effect of Social Capital on Organizational Performance,

Linear Regression (South Korea) ...........................................99

Table 26: ANOVA of Agency Type and Factors (South Korea) .......................99

Table 27: Mean of Culture and Social Capital and Organizational Performance by Agency Type (South Korea) ........................................... 100

Table 28: Dummy Regression of Agency Type and Culture and

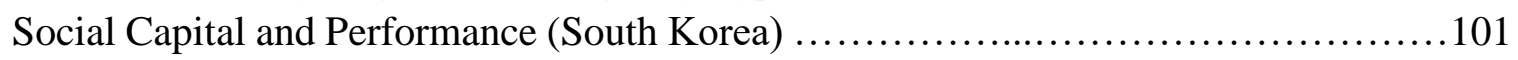

Table 29: Effect of Social Capital on Organizational Performance, Moderator Regression - Model Summary ${ }^{\mathrm{d}}$ (South Korea) .........................................103

Table 30: Effect of Social Capital on Organizational Performance,

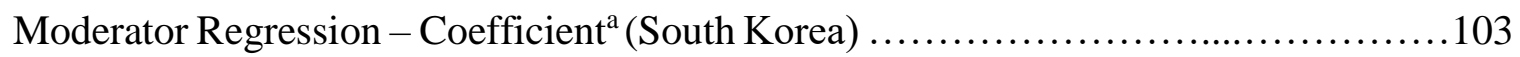

Table 31: Survey Distribution and Response (The United States) .....................104

Table 32: Descriptive Statistics of Survey Respondents (The United States) ...........105

Table 33: Factor Analysis and Reliability Analysis (The United States) ..............106

Table 34: KMO and Bartlett's Test (The United States) .......................... 108

Table 35: Goodness-of-Test (The United States) ...............................108

Table 36: Mean and Standard Deviation by Factors (The United States) ...............109

Table 37: Mean and Standard Deviation by Variables (The United States) ............110

Table 38: Correlations of Culture and Social Capital and Organizational

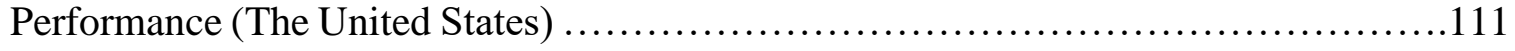

Table 39: t-test of Gender and Factors (The United States) .........................112

Table 40: Effect of Social Capital on Organizational Performance, 
Linear Regression (The United States) .........................................114

Table 41: ANOVA of Agency Type and Factors (The United States) ..................114

Table 42: Mean of Culture and Social Capital and Organizational Performance by Agency Type (The United States) …..................................... 115

Table 43: Dummy Regression of Agency Type and Culture and Social Capital and Performance (The United States) ................................116

Table 44: Effect of Social Capital on Organizational Performance, Moderator Regression - Model Summary ${ }^{\mathrm{d}}$ (The United States) ........................117

Table 45: Effect of Social Capital on Organizational Performance, Moderator Regression - Coefficient $^{\mathrm{a}}$ (The United States) …....................118

Table 46: Survey Distribution and Responses (Total)..............................118

Table 47: Descriptive Statistics of Survey Respondents (Total)......................119

Table 48: Factor Analysis and Reliability Analysis (Total).........................120

Table 49: KMO and Bartlett's Test (Total) ......................................122

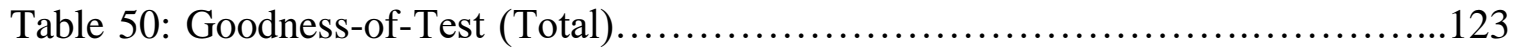

Table 51: Mean and Standard Deviation by Factors (Total)...........................123

Table 52: Mean and Standard Deviation by Variables (Total).........................124

Table 53: Correlations of Culture and Social Capital and

Organizational Performance (Total) ............................................. 125

Table 54: t-test of Gender and Factors (Total).....................................126

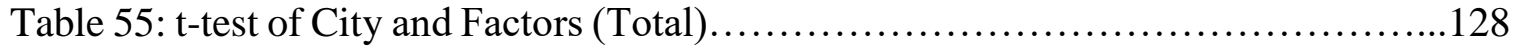

Table 56: Effect of Social Capital on Organizational Performance,

Linear Regression (Total) ..................................................... 130

Table 57: ANOVA of Agency Type and Factors (Total).............................130

Table 58: Mean of Culture and Social Capital and Organizational Performance

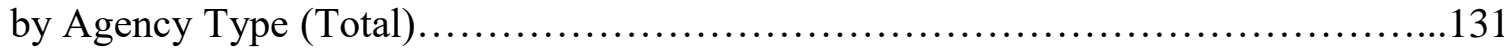


Table 59: Dummy Regression of Agency Type and Culture and Social Capital and Performance (Total).

Table 60: Dummy Regression of City Type and Culture and Social Capital and Performance (Total)

Table 61: Effect of Social Capital on Organizational Performance, Moderator Regression - Model Summary ${ }^{\mathrm{d}}$ (Total).

Table 62: Effect of Social Capital on Organizational Performance, Moderator Regression - Coefficient $^{\mathrm{a}}$ (Total)..................................136

Table 63: Hypothesis Test Results........................................ 143

Table 64: Influential Factors' Ranking by Groups.............................. 144

Table 65: City Selection Criteria (The City of Omaha) ............................ 169

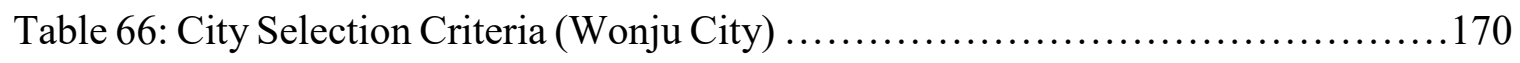

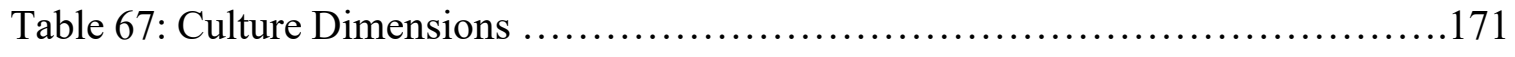




\section{CHAPTER 1: INTRODUCTION}

\section{Motivation of the Study}

Interest in the concept of social capital has increased over the past 20 years, kindled by the seminal work by Bourdieu (1986), Coleman (1988), and Putnam (1993). The present study contributes to the literature on social capital by analyzing how organizational level social capital in a public sector organization affects governmental performance in different cultural contexts.

As an intangible resource, social capital can be defined as trust, shared norms, and networks (Putnam, 1993) within an organization. Social capital encourages organizational development and increases the efficiency of a society. Scholars have also related this concept to economic growth, community development, political participation, and organizational performance at various levels of government (Barnard, 1938; Boix \& Posner, 1998; Coleman, 1998; Goldfinger \& Ferguson, 2009; Harrington, 2001; Knack, 2002; Nahapiet, 1998; Ofori \& Sackey, 2010; Pierce, Lovirch \& Moon, 2002; Rice, 2001).

The relationship between social capital and governmental performance has been studied at national (Booth \& Richard, 1998), regional (Putnam, 1993; Rice \& Sumberg, 1997), local (Cusack, 1999; Rice, 2001), and organizational levels (Andrews, 2010). Social capital positively influences organizational performance in public sectors in terms of efficiency, effectiveness, equity, and responsiveness (Brudney \& England; Kim, 1999; Kim \& Kim, 1996; Morgan, 1988; Ostrom, 2000). 
Mayo's Hawthorne experiment ${ }^{1}$ (Mayo, 1993) showed that, compared to the traditional scientific management method (i.e., control and direction from management), laborers are more sensitive to social pressure from colleagues. Namely, the social or psychological aspects that the human relations school emphasized has an important influence on performance. Similarly, according to Jung and Lee's study (2012), social relations and participative management style have stronger influences than physical conditions on public employees' perceived performance. Barnard (1938) also emphasized the importance of informal organizational networks as one of the components of social capital — that is, considering organizations as cooperative systems. According to leadermember exchange theory, in-group members who are given greater responsibilities, more rewards, and more attention have higher productivity, job satisfaction, and motivation, and have low turnover rate and engage in more citizenship behaviors than out-group members who are outside the leader's inner circle, and thus receive less attention and fewer rewards, and are managed by formal rules and policies (Lunenburg, 2010; Chen, Lam, \& Zhong, 2007; Graen \& Uhl-Bien, 1995).

Social capital as moral capital increases when it is used; if not used, it is exhausted. Social capital has potential power that can enhance social performance compared to other capitals (Coleman, 1988). The reason is that other capitals-namely, material resources and human resources - can be depleted, but the more social capital is

\footnotetext{
${ }^{1}$ The Hawthorne studies were conducted by Mayo and his colleges in the Western Electric Hawthorne plant, which is near Chicago, in the late 1920s to the early 1930s. The main theme of the experiment was to prove the relationship between working environment and productivity through scientific management theory. However, the studies showed the importance of the individual and the presence of a social system in the workplace. Productivity increased regardless of lighting level and increased productivity was due to workers' receiving attention.
} 
used, the more its efficiency increases (Ferguson et al., 2005; Fukuyama, 1995; Kim \& Lee, 2000; Kim, 1999; Lee, Park \& Jeon, 2007; Rice, 2001; World Bank, 2000).

Therefore, the increase in the value of social capital could be very significant in relation to performance. To develop and solve organizational problems, consensus and cooperation among members of an organization is needed. High performing organizations tend to have low transaction costs based on a high level of trust, the spirit of cooperation, and knowledge sharing. That is, social capital in organizations can be beneficial when properly utilized.

Social capital positively influences organizational performance (Andrew, 2010; Behn, 1995; Boix \& Posner, 1998; Coleman, 1988; Putnam, 1993). Social capital exists in social relationships among actors, and the relationships are created by exchange of social interactions. The exchange process leads to differentiation of power and privilege in social groups (Cropanzano \& Mitchell, 2005). In a related matter, researchers have studied the relationship between social capital and economic development, or the effect of organizational social capital on the development of local and national governments (Boix \& Posner, 1998; Goldfinger \& Ferguson, 2009; Harrington, 2001; Ofori \& Sackey, 2010; Rice, 2001). These researchers suggest that trust and networks affect organizational performance and effectiveness in a positive way.

In public administration, social capital discourse is structured into three themes (Ganapati, 2013). They relate to: (1) how social capital is created, maintained, or destroyed in the public realm; (2) the social capital of public servants; and (3) the consequences of social capital for public administration. Most studies (Andrews, 2010; Bandiera et al., 2008; Soctt, 1999; Willem \& Buelens, 2007) in public administration 
focus on the benefits of social capital as an independent variable, and public administration researchers usually measure social capital using interviews and surveys such as the World Value Survey and Korean General Social Survey.

\section{Statement of Purpose}

Numerous studies have shown that social capital, defined as trust, networks, and norms of reciprocity, can influence organizational performance. What is less understood, however, is how the relationships between social capital and organizational performance of public service organizations vary by type of government agency. According to Newman (1994), the working environment of each of Lowi's agency types-including distributive agency, redistributive agency, and regulatory agency—is distinctive and predicts leadership styles and patterns of career advancement. Each agency has its own political structure, political process, elite, and group relations (Lowi, 1964). Also, each agency has different missions and responsibilities they must carry out. The distinctive features of each agency type may influence organizational social capital, such as trust and networks and organizational performance. Therefore, the present study will examine how agency type —including distributive, redistributive, and regulatory—influences social capital and organizational performance.

What is less understood is how cultural differences among countries may affect the relationship between social capital and organizational performance. Prior work by Hofstede (2001) on the link between culture and trust demonstrates that levels of trust vary among countries depending on their cultural values regarding power distance, uncertainty avoidance, individualism, masculinity, and long-term orientation. Given that 
trust is by definition part of social capital, I expect that the effect of organizational level social capital in a public sector organization on organizational performance will differ across countries based on cultural values. Therefore, the present research will examine how organizational level social capital in a public sector organization influences organizational performance in two different cultures: American and Korean.

The research questions that guide my study are: "What is the effect of social capital of public service organizations (if any) on organizational performance in local government organizations?" and "How does social capital influence organizational performance in different cultures?" and "Within a given culture, how does this relationship vary by the types of government agency?" First, this study examines the theory and concept of social capital and analysis model via a theoretical discussion to test the effect of organizational social capital on organizational performance. Second, this study examines the levels of social capital by reviewing the literature and analyzing the causal relationship between social capital and organizational performance. Third, this study explores ways of improving social capital to improve performance in the relationship between social capital and organizational performance.

\section{Significance of the Study}

This is the first study to analyze how culture affects the relationship between social capital and organizational performance and whether culture, social capital, and organizational performance differ according to agency type in the public sector. Since improving performance is a main objective of every government agency, it is important to understand how culture influences social capital in order to enhance organizational 
performance. By integrating public organizational theories with the literature on social capital, this study contributes to the ongoing debate on the determinants of public sector performance. Moreover, the study examines performance by breaking it down into the four components commonly noted by scholars: efficiency, effectiveness, equity, and responsiveness.

This research clarifies the causal relationship between social capital of public service organizations and organizational performance and how it varies depending on national culture. The findings of the study can provide public administrators with practical advice on how to improve organizational performance by emphasizing particular cultural values and societal expectations.

By analyzing the factors that influence organizational performance in different cultures, this study is able to suggest how to improve organizational performance. Knowing the impact of social capital would provide important information and possibly encourage other cities to adopt such measures. Thus, this study provides both practitioners and scholars with a better understanding of the relationships between social capital and organizational performance-measured in a variety of dimensions. This is the study's main theoretical contribution to the field of public administration.

\section{Background}

\section{Social Capital and Organizational Performance}

Previous research identifies two main mechanisms through which social capital affects organizational performance: trust and the existence of networks. 
Trust, as one factor of social capital, plays a role as the basis for participation in learning activities and exchange of knowledge and information (Kim \& Lee, 2000; Kim, 1999; Lee, 1996). In the case when an interrelationship is not based on trust, it is difficult to exchange and deliver knowledge. Trust facilitates participation in the exchange of knowledge and information, creation of knowledge, and motivation for participation in knowledge creation. Differentiating among various types of capital-physical capital, human capital, and social capital-Coleman (1988) argues that all are necessary for productive action. Social capital based on trust among doers promotes productive action, although it is not concrete-while physical capital and human capital are tangible. For example, a group having strong trust and beliefs can attain better performance than a group lacking these characteristics. Boix \& Posner (1998) argue that trust among participants increases efficiency of economy. According to Behn (1995), mistrust strengthens regulations and rules, which in turn decreases performance.

Besides trust, the existence of a network contributes to the development of intellectual capital as it influences the exchange of knowledge and learning action (Krackhardt, 1992). The formation of networks promotes communication of information and knowledge (Burt, 1997). The co-operational relations bring out efficiency in organizational performance.

Agency Type

According to organizational theorists, the structure and behavior of institutions depends on the character of the institution itself, its predominant culture, and the 
characteristics of the policies (Newman, 1994). Lowi categorized the typology of agencies according to the characteristics of the policies.

Lowi (1974) distinguishes between four policy types: regulatory policy, distributive policy, redistributive policy, and constituent policy. Government agencies are charged with the implementation of various policies. Agency types are related to the goals of specific policies, which are in turn reflected in the mission statements of government agencies. Lowi (1974) adds one more agency model to the original three: the constituent agency model ${ }^{2}$. This fourth agency model is not immediately relevant to this study, as it focuses on boundary and jurisdictional issues rather than on functional or policy content (Lowi, 1972; Newman, 1994; Wright, 1988). Lowi’s policy typology has been used as a theoretical basis by many public administration scholars (Gooderham \& Nordhaug, 2001; Leana \& Pil, 2006; Newman, 1994; Sanders, 1990; Yoo et al., 2011).

\section{Culture}

The notion of national culture has been extensively studied by Hofstede (2001), Inglehart (1997), Schwartz (1994), and many other researchers. This study adopts Hofstede's definition and theoretical framework. Hofstede (2001) defines national culture as "the collective programming of the mind that distinguishes the member of one group or category of people from another" (2001: 9). National culture is considered an important predictor of how people think and act in any given society. Moreover, cultural values play a significant role in how people perceive government transparency and trust

\footnotetext{
${ }^{2}$ Constituent agencies carry out a residual group of polices that do not fit among the other three-serving government in general or the nation as a whole - and include the polices: reapportionment, setting up a new agency, and propaganda.
} 
(Grimmelikhuijsen et al., 2013). Nevertheless, no study has examined the effect of social capital from a cultural perspective. Hofstede (2001) developed cultural indices for a number of countries, including the United States and South Korea. The indices are constructed along five dimensions: power distance, uncertainty avoidance, individualism/collectivism, masculinity/femininity, and Confucian/dynamism. This study makes use of Hofstede's framework, within which the U.S. and South Korea contrast strongly on most important cultural characteristics. These countries are chosen as comparative countries based on Hofstede's work on national cultures.

\section{Variables}

The variables of culture, social capital, and organizational performance were developed and measured on the basis of the literature review and the objectives of the study.

Culture variables as measured by Hofstede considered include:

- Power distance: This is measured in terms of decision making, opinion, social interaction, agreement with decision, and delegating important tasks.

- Uncertainty avoidance: This is measured in terms of having instructions, following instructions and procedures, importance of rules and regulations, standardized work procedures, and importance of instructions for operations.

- Collectivism: This is measured in terms of sacrificing self-interest, individuals' sticking with the group even through difficulties, group 
welfare, group success, and individuals' goal, group loyalty.

- Long-term orientation: This is measured in terms of thriftiness, persistence, personal steadiness and stability, long-term planning, giving up today's fun for success, working hard for future success.

- Masculinity: This is measured in terms of professional career, problem solving, solving difficult problems, and jobs.

Organizational social capital variables considered include:

- Structural social capital: This is measured in terms of internal coordination, external co-ordination, internal connectivity, and external connectivity.

- Relational social capital: This is measured in terms of interpersonal trust (local government head, top-management and staff, co-worker, local assembly man, and citizen) and institutional trust (public servants labor union, local council, community organization, and other departments).

- Cognitive social capital: This is measured in terms of understanding of mission, values, and objectives, value of objectives, conflict with objectives, and achievement of objectives.

Organizational performance variables considered include:

- Efficiency: This is measured in terms of business process time reduction, business process cost cutting, accuracy of business process, and administrative efficiency improvement.

- Effectiveness: This is measured in terms of goal attainment, qualitative satisfaction, and quantitative satisfaction. 
- Responsiveness: This is measured in terms of reflection of client (citizen)'s desire, customer satisfaction, and addressed client demands in a timely manner.

- Equity: This is measured in terms of distributive equity, procedural equity, and interactional equity.

\section{Methods, Data Collection, and Sample}

The main objective of this study is to analyze the impact of social capital on organizational performance in different cultural contexts. In order to examine the levels of social capital and the factors affecting organizational performance, a survey was sent to public officials in the city of Omaha ${ }^{3}$, Nebraska in the United States and Wonju City ${ }^{4}$ in South Korea. These cities are chosen as typical representatives of each country. More specifically, the cities are selected to be as close as possible to the national averages on different criteria, such as percentage of ethnic minorities, education level, income, and sectors of economy.

The survey was distributed to governmental departments within the two cities. I follow the approach of previous studies (e.g., Newman, 1994) and based the selection of the departments on Lowi's classification of policy types. Lowi's (1985) framework is

\footnotetext{
${ }^{3}$ Omaha is located in the Midwestern United States and is the largest city in the state of Nebraska with a population of 434,353. The city of Omaha operates under a Mayor-Council form of government. The mayor and the seven City Council members are elected to four year terms.

${ }^{4}$ Wonju is located in central Korea and the most populous city in Gangwon province, South Korea, with a population of 323,885. Wonju city operates under a Mayor-Council form of government. The mayor and the two City Council members are elected to four year terms.
} 
based on four models: the distributive agency model, redistributive agency model, regulatory agency model, and constituent agency model. As mentioned above, this study focuses on three agency types: distributive agency, redistributive agency, and regulatory agency because the constituent agency model is not relevant to this study.

Therefore, I selected the departments that matched the policy categories identified by Lowi. The agencies selected in the city of Omaha, Nebraska, in the United States include public works (distributive agency), human rights and relations and human resources (redistributive agency), and permits and inspections, urban planning, and housing and community (regulatory agency). In the case of South Korea, the departments selected in Wonju city include health and physical education, parks, information and communication, and forests (distributive agency); welfare policy, livelihood security, and women and family (redistributive agency); and traffic administration, architecture, and construction accident prevention (regulatory agency). A greater number of departments are selected within Wonju city to compensate for the larger number of staff employed in the departments of the city of Omaha.

The survey was distributed to 407 respondents in the two cities. It includes items that feature Likert-type scales - mostly ordinal level responses (e.g., 1. strongly disagree, 2. disagree, 3. neutral, 4. agree, and 5. strongly agree). The unit of analysis is the public service organization. The main variable is operationalized using survey data. To test the hypothesized effects of culture and social capital on agencies' performance, the study uses various statistical techniques, including t-test, factor analysis, correlation analysis, regression analysis, dummy regression analysis, and moderated regression analysis. 


\section{Overview of the Study}

The main purpose of this study is to examine the relationships between organizational level social capital in a public sector organization and organizational performance in two distinct cultures: American and Korean. To develop this investigation, this study proceeds as follows:

Chapter 2 provides the theoretical background of this study. More specifically, this chapter reviews the relevant literature related to social capital, organizational performance, culture, and agency type, including their definitions, aspects, measures, and indicators. The chapter closes with a presentation of theories and hypotheses to explain the factors influencing organizational performance.

Chapter 3 describes the research methodology, including descriptions of key characteristics of the sampled cities, the departments in the study, and the population from which the sample was drawn. The chapter also provides details about each variable related to subsystem criteria tested, as well as the statistical tools used to conduct the analysis in this study.

Chapter 4 presents the results of the study and includes a descriptive review of each variable and each element of the subsystems used in this study: quantitative analysis through t-tests and predictive results from the regression analysis.

Chapter 5 presents a discussion of the major findings, theoretical contribution, and policy implications of this study, as well as the limitations of the study. It also offers recommendations for future research and practice. 


\section{CHAPTER 2: LITERATURE REVIEW AND HYPOTHESES}

This chapter provides a literature review of social capital, organizational performance, culture, and agency type, including the definition, levels, types, dimensions, and measurements of these entities. The chapter also examines theories and hypotheses to explain the factors influencing organizational performance.

\section{Social Capital}

\section{Introduction}

The term "capital" broadly refers to a resource that can be used to mobilize social and cultural resources, as well as economic ones, for the creation of wealth. Various types of capital exist. The term capital originates from economic capital, but its use has subsequently expanded into other areas. The form of capital in play depends on the field of production: social, human, and cultural. Like economic capital, each of these forms of capital can be accumulated.

First, human capital, as introduced by Becker (1965), is considered to be the enhanced worth of an individual — measured by increased productivity in the workplace. Human capital refers to the innate skills, knowledge, and capabilities of individuals. Human capital is the accumulated knowledge acquired by each individual (Coleman, 1988). Second, cultural capital—which refers to the knowledge, competencies and dispositions valued by the dominant culture (Bourdieu, 1993) — refer to the information and knowledge that are strategically utilized by the privileged classes. The education 
system is a vehicle of social reproduction, because it reproduces, reinforces, and rewards acts, values, and behaviors that are valued by the privileged classes of society. For Bourdieu, social capital is composed of social obligation or connections.

Social capital is not easily defined because it is multidimensional. The concept of social capital was introduced by sociologists Bourdieu and Coleman in the 1980s (Portes, 2000). Since then, many definitions of social capital have been offered. Scholars, and research areas, differ in their approaches to social capital. The representative scholars who influence social capital are Bourdieu, Coleman, and Putnam.

First, Bourdieu (1986) developed a social capital theory using a macro perspective and divided capital into three types: economic capital, cultural capital, and social capital. Social capital in a macro view mainly focuses on political culture and organizational characteristics of community and aggregation, while the micro view tends to focus on the relationship type of the individuals or group (Burt, 1992; Putnam, 1993; Lin, Cook, \& Burt, 2001). Bourdieu (1986) defines social capital as "the aggregate of the actual or potential resources which are linked to possession of a durable network of more or less institutionalized relationships of mutual acquaintance and recognition of membership in a group — which provides each of its members with the backing of the collectively-owned capital, a credential which entitles them to credit, in various senses of the word" (248249). Bourdieu's concept of social capital includes trust, norms, and network. He indicated that social capital means more than simple network ties and social capital has to be trustworthy and positive. Moreover, he stressed the role of networks, and that the required networks demanded more than mere friendship in the social capital 
transformation process. Therefore, in his view, in the absence of networks, social capital does not occur.

In contrast to Bourdieu's macro perspective, Coleman and Putman established social capital theories from a micro perspective. While Bourdieu excluded origin and effect in defining social capital, Coleman (1990) included the effect and function of social capital. Thus, he combined social capital and trust, and attempted to define social capital through the comparison of social capital and physical or human capital.

Coleman defines social capital as "a variety of entities having two characteristics in common: They all consist of some aspect of social structures, and they facilitate certain functions of individuals who are within the structure" (Coleman, 1990: 302). Coleman describes social capital as social-structural resources that serve as a capital asset for the individual. According to Coleman, social capital is present in social ties or in the structure of relations among actors based on reciprocal trust. Social capital exists in the network structure between persons and among people, and it can also be conceptualized as an asset to a collective as well as an individual. By putting emphasis on social connectedness and the degree of social cohesion, social capital inheres within the structure of relations between persons and among persons. Coleman identifies three elements that could help social relationships: (1) trust of obedience (a sense of duty) and expectation, (2) compassion and social norms to promote a common good beyond an individual's selfishness, and (3) social networks (data channels). According to Coleman (1990), like other forms of capital, social capital is productive, making possible the achievement of certain ends. Synergy and collaboration can be easily achieved when 
social capital exists within a community or a society. Therefore, he considered social capital as a productive concept.

Coleman dealt with social capital in terms of comprehensive and social interactions. In contrast, Putman emphasized the application of social capital and referred to social capital as "features of social organization such as trust, norms and networks that can improve the efficiency of society by facilitating coordinated actions" (Putnam, 1993: 167). Also, Putman (1995) defined the concept of social capital as characteristics of the social structure (e.g., trust, norms, and networks) that can make participants cooperate and thereby achieve shared goals more efficiently. In this way, he stressed the ability of social capital to facilitate cooperation. Similarly, he also defines social capital as connections among individuals. Individual connections are "social networks and the norms of reciprocity and trustworthiness that arise from them" (Putnam, 2000: 19). His arguments show that networks are systems of civic engagement-with the focus on horizontal networks rather than vertical networks. He conceptualized associations or networks as horizontal groups of individuals who influenced the community's social productivity. Moreover, he argued that networks create trust, the norm of mutualism, and the capability of citizen participation in modern democracy.

Aside from Bourdieu, Putnam, and Coleman, many other scholars examined the concepts and components of social capital, as shown in Table 1. 
Table 1: Concepts and Components of Social Capital

\begin{tabular}{|c|c|c|c|}
\hline Scholar & Definition & Components & $\begin{array}{l}\text { Common } \\
\text { Components }\end{array}$ \\
\hline $\begin{array}{l}\text { Tocqueville } \\
\text { (1984) }\end{array}$ & & $\begin{array}{l}\text { Spirit of community } \\
\text { Voluntary } \\
\text { participation } \\
\text { Personal } \\
\text { responsibility and } \\
\text { sense of belonging }\end{array}$ & \multirow{7}{*}{$\begin{array}{l}\text { Trust } \\
\text { Network } \\
\text { Norm }\end{array}$} \\
\hline $\begin{array}{l}\text { Bourdieu } \\
\text { (1986) }\end{array}$ & $\begin{array}{l}\text { "the aggregate of the actual or potential } \\
\text { resources which are linked to possession } \\
\text { of a durable network of more or less } \\
\text { institutionalized relationships of mutual } \\
\text { acquaintance or recognition" (1985: } 248) \text {. } \\
\text { "made up of social obligations } \\
\text { ('connections'), which is convertible, in } \\
\text { certain conditions, into economic capital } \\
\text { and may be institutionalized in the form } \\
\text { of a title of nobility" (1985: } 243) \text {. }\end{array}$ & $\begin{array}{l}\text { Intimacy } \\
\text { Reciprocal } \\
\text { relationship }\end{array}$ & \\
\hline $\begin{array}{l}\text { Coleman } \\
\text { (1988) }\end{array}$ & $\begin{array}{l}\text { "the ability to secure benefits through } \\
\text { membership in networks and other social } \\
\text { structures" }(1988,8)\end{array}$ & $\begin{array}{l}\text { Trust relationship } \\
\text { among people } \\
\text { Reciprocity } \\
\text { Norm }\end{array}$ & \\
\hline $\begin{array}{l}\text { Putnam } \\
\text { (1993) }\end{array}$ & $\begin{array}{l}\text { "features of social organization, such as } \\
\text { trust, norms, and networks, that improve } \\
\text { the efficiency of society by facilitating co- } \\
\text { ordinated actions" }(1993,167)\end{array}$ & $\begin{array}{l}\text { Trust } \\
\text { Norm } \\
\text { network }\end{array}$ & \\
\hline $\begin{array}{l}\text { Nahapiet \& } \\
\text { Ghoshal } \\
(1998)\end{array}$ & $\begin{array}{l}\text { "the sum of the actual and potential } \\
\text { resources embedded within, available } \\
\text { through, and derived from the network of } \\
\text { relationships possessed by an individual } \\
\text { or social unit. Social capital thus } \\
\text { comprises both the network and the assets } \\
\text { that may be mobilized through that } \\
\text { network" (1998: 243). }\end{array}$ & Network & \\
\hline $\begin{array}{l}\text { Portes } \\
\text { (1988) }\end{array}$ & $\begin{array}{l}\text { "the ability to secure benefits through } \\
\text { membership in networks and other social } \\
\text { structures" }(1988,8)\end{array}$ & Network & \\
\hline $\begin{array}{l}\text { Inglehart } \\
\text { (1997) }\end{array}$ & $\begin{array}{l}\text { "a culture of trust and tolerance, in which } \\
\text { extensive network of voluntary } \\
\text { associations emerge" }(1997,188)\end{array}$ & $\begin{array}{l}\text { Trust } \\
\text { Network }\end{array}$ & \\
\hline
\end{tabular}




\begin{tabular}{|c|c|c|}
\hline $\begin{array}{l}\text { Innes et al. } \\
\text { (1994) }\end{array}$ & & $\begin{array}{l}\text { Personal network } \\
\text { Trust } \\
\text { Communication }\end{array}$ \\
\hline $\begin{array}{l}\text { Fukuyama } \\
\text { (1997) }\end{array}$ & $\begin{array}{l}\text { "the ability of people to work together for } \\
\text { common purposes in groups and } \\
\text { organizations" (1995,10), "social capital } \\
\text { can be defined simply as the existence of } \\
\text { a certain set of informal values or norms } \\
\text { shared among members of a group that } \\
\text { permit cooperation among them" (1997) }\end{array}$ & Trust \\
\hline $\begin{array}{l}\text { Healey } \\
(1995)\end{array}$ & $\begin{array}{l}\text { "a capability that arises from the } \\
\text { prevalence of trust in a society or in } \\
\text { certain parts of it" (1995: } 26)\end{array}$ & $\begin{array}{l}\text { Formation of } \\
\text { network }\end{array}$ \\
\hline $\begin{array}{l}\text { Knoke } \\
(1999)\end{array}$ & $\begin{array}{l}\text { "the process by which social actors create } \\
\text { and mobilize their network connections } \\
\text { within and between organizations to gain } \\
\text { access to other social actors' resources" } \\
(1999: 18) \text {. }\end{array}$ & Network \\
\hline $\begin{array}{l}\text { Loury } \\
\text { (1992) }\end{array}$ & $\begin{array}{l}\text { "naturally occurring social relationships } \\
\text { among persons which promote or assist } \\
\text { the acquisition of skills and traits valued } \\
\text { in the marketplace... an asset which may } \\
\text { be as significant as financial bequests in } \\
\text { accounting for the maintenance of } \\
\text { inequality in our society" (1992: 100). }\end{array}$ & Relationship \\
\hline $\begin{array}{l}\text { Moran } \\
(2005)\end{array}$ & $\begin{array}{l}\text { "a valuable asset and that its value stems } \\
\text { from the access to resources that it } \\
\text { engenders through an actors' social } \\
\text { relationships" (2005:1129) }\end{array}$ & Relationship \\
\hline $\begin{array}{l}\text { MSU SCIG } \\
(1988)\end{array}$ & & Network \\
\hline $\begin{array}{l}\text { Woolcock } \\
\& \text { Narayan } \\
(2000)\end{array}$ & $\begin{array}{l}\text { "the information, trust, and norms of } \\
\text { reciprocity inhering in one's social } \\
\text { networks" (1998: 153) }\end{array}$ & $\begin{array}{l}\text { Communitarian } \\
\text { Network } \\
\text { Institution } \\
\text { Synergy }\end{array}$ \\
\hline $\begin{array}{l}\text { World } \\
\text { Bank } \\
(1998)\end{array}$ & & $\begin{array}{l}\text { Network } \\
\text { Norm }\end{array}$ \\
\hline
\end{tabular}


However, scholars do not agree on a single concept or factor to define social capital; however, in general, factors such as network, trust, and the norm of reciprocity are used in defining social capital. As presented in Table 2, common factors provided by scholars are trust, networks, and norms. These parallel Putnam's components.

Table 2: Summary of the Components of Social Capital by Scholars

\begin{tabular}{|l|c|c|c|}
\hline Scholar & Trust & Norms & Networks \\
\hline Tocqueville (1984) & & $\checkmark$ & $\checkmark$ \\
\hline Bourdieu (1985) & & $\checkmark$ & \\
\hline Coleman (1988) & $\checkmark$ & & $\checkmark$ \\
\hline Putnam (1993) & $\checkmark$ & & $\checkmark$ \\
\hline Portes (1988) & $\checkmark$ & & $\checkmark$ \\
\hline Inglehart (1997) & $\checkmark$ & $\checkmark$ & $\checkmark$ \\
\hline Innes et al. (1994) & $\checkmark$ & & $\checkmark$ \\
\hline Fukuyama (1997) & $\checkmark$ & $\checkmark$ & $\checkmark$ \\
\hline Healey (1995) & & & $\checkmark$ \\
\hline Knoke (1999) & $\checkmark$ & & $\checkmark$ \\
\hline MSU SCIG (1998) & & & $\checkmark$ \\
\hline Woolcock \& Narayan (2000) & & & $\checkmark$ \\
\hline World Bank (1998) & & & $\checkmark$ \\
\hline
\end{tabular}

Many researchers have developed conceptual components of social capital. Social capital can be understood by distinguishing two interrelated categories of phenomena: structural and cognitive. Grootaert and Bastelater (2002) divided social capital into two 
factors, which are structural social capital and cognitive social capital. Structural social capital is a relatively objective and externally observable social structure. Networks and associations are included in structural social capital, while cognitive social capital as an invisible factor is more subjective and includes attitude, behaviors, norms, shared values, reciprocity, and trust (Grootaert \& Bastelater, 2002: 19-21). Harpham (2002) divided social capital into two categories: structural factors and cognitive factors. He argued that structural factor is association connection and the range and strength of activity, and includes support, reciprocity, sharing, and trust. According to Harpham, structural factors can be characterized by what people 'do' and cognitive factors are characterized by what people 'feel' (Harpham et al., 2002: 106). Also, Uphoff (1999) distinguished between structural and cognitive social capital. The structural category is associated with various forms of social organization, roles, rules, precedents and procedures, and networks. The cognitive category derives from mental processes and resulting ideas - such as norms, values, attitudes, and beliefs. Additionally, Nahapiet and Ghoshal (1998) provided three dimensions of social capital: structural, relational, and cognitive. Although these dimensions are interrelated, distinguishing between them helps the analysis of the complex interactions among actors (Subramaniam et al., 2013). In sum, organizational social capital consists of the structural (networks and connections among actors), relational (trust between actors), and cognitive (values and shared norms) dimensions of the relationships between organization members (Andrew, 2010; Nahapiet \& Ghoshal, 1998; Subramaniam, Stewrt, Ng, \& Shulman, 2013). The present study utilizes these three dimensions. 
Based on the literature review, the present study defines social capital as a characteristic of social organizations - including trust, networks, and norms among organizations and among organizational members - that can improve the effectiveness of society by inducing cooperation behavior.

\section{Background of Social Capital}

Social capital theory is regarded as a core factor that can solve societal and national problems. Research on this topic is booming. For example, the concept of social capital is being used in almost all fields of study, and the World Bank is utilizing the concept to facilitate advancement in developing countries. In addition, social capital played an important role in the Washington Consensus, ${ }^{5}$ accomplished by the United States, IMF, and World Bank (Williamson, 1990). As the role of social capital becomes bigger, the research field of social capital has become more widespread over political science and sociology. The background of social capital is divided into its academic origin and its theoretical formation process how it forms, changes over time and is destroyed.

\section{Academic Origin of Social Capital}

In general, scholars agree that Hanifan (1916) introduced the concept of social capital for the first time. She regarded trust, friendship, and reciprocal feelings as

\footnotetext{
5 The terminology Washington Consensus was used by Williamson in 1989. The Washington Consensus is a set of 10 economic policy prescriptions considered to constitute the standard reform package promoted for developing countries by IMF, World Bank, and the US Treasury Department: (1) fiscal policy discipline, (2) redirection of public spending, (3) tax reform, (4) interest rates, (5) competitive exchange rates, (6) trade liberalization, (7) liberalization of inward foreign direct investment, (8) privatization of state enterprises, (9) deregulation, and (10) legal security for property rights.
} 
components of social capital and emphasized the importance of participation in the education of local society. However, her efforts were obscured and the term social capital faded for a while.

The discussion of social capital reappeared at the end of the 1970s and spread into economics, sociology, and political science. In the 1990s, it was used in almost all fields of study as a result of Putnam's popularization of the concept. The formation process of social capital is multidisciplinary and its methodology is varied. Therefore, the discussion of social capital's background should not be limited to certain research areas or to specific scholars. However, the present study examines how the theory of social capital evolved in economics, sociology, and political science.

The development process of social capital that emerged in political science is closely related to civil society theory, which itself developed from discussions among classical political economists that aimed to cultivate the autonomy of the market and society to the nations and to secure legitimacy of criticism about the mercantilism state (Chanddhoke, 1995). In this regard, social capital theory is basically an extension of liberal civil society theory (Edwards \& Foley, 2001: 7). Civil society refers to a coalition of autonomous people that can supervise and control a nation. Simultaneously, civil society was regarded as serving a function that governments are incapable of accomplishing. According to this, from a perspective that the potential of civil society can be measured in the political science field, social capital theory is actively discussed (Putnam, 1993; Park \& Kim, 2003). 
Meanwhile, social capital in sociology emerged with a sociological research theme, namely, human relations or social relations. That is, this perspective saw that social capital extends the concept of traditional capital, which is a factor of production in neo-classical economics. Academic genealogy of economic analytics and the academic line of the neo-classical and neo-institutionalism schools coexist when the concept of social capital is discussed. In this regard, the concept of social capital—originating from neo-institutionalism and neo-utilitarianism, which developed from marginal utility theory of the neo-classical school—is applied to human relations and social systems (Coleman, 1990). Therefore, it is important to include the concept of human capital and culture capital when social capital theory is discussed.

\section{Formation Background of Social Capital}

The characteristics of social capital theory are considered opaque because the theory developed under various perspectives (i.e., in accordance with the respective field of study). However, as noted above, social capital theory can be divided into the macro view and the micro view when considering the development process and tendencies of social capital. Bourdieu (1980) developed social capital using a macro perspective, while Coleman (1988) and Putnam (1993) discussed social capital to examine the formation

process of the theory using a micro perspective. The reason why Bourdieu, Coleman, and Putnam discussed the development process of social capital theory is that the distinguishing difference among them exists despite several similarities. The differences are detailed in the following paragraphs. 
First, the researchers differ in their views on the occurrence and attribution of social capital. In Bourdieu's view, social capital belongs to individuals, while Coleman indicates that social capital is produced in an individual relationship. Second, the researchers differ in their views on the unit of empirical analysis of social capital. Bourdieu and Coleman regard the individual as the unit of analysis, whereas Putnam viewed local society or nations as the unit of analysis. Finally, the researchers differ in their views on analyzing social capital. In the view of Bourdieu and Coleman, social capital provides competitive profits to individuals, but personal benefits do not necessarily involve positive social results. On the other hand, Putnam noted that social capital involves positive effects for local society and the nation.

Macro Perspective of Social Capital. Bourdieu developed a social capital theory using a macro perspective and divided capital into three types (i.e., economic capital, cultural capital, and social capital) in his 1986 book The Capital Form. Moreover, he argued that to demonstrate these three forms' function as capital, they could all be transformed into another type of capital at an expense. Bourdieu's concept of social capital includes trust, norms, and networks. He considered networks to be core content from the structural perspective of social capital and emphasized the role of networks and that continuous efforts are necessary to create and maintain networks. He stressed that to gain social capital, considerable investment was necessary to establish and maintain relationships and noted that individuals who had no capability to deal with them could not even access such networks. 
Bourdieu first developed the concept of cultural capital and then introduced the idea of social capital. He developed the concept of social capital because he had doubts about the reproduction and cycling of class differentiation in society. He noted the process by which class differentiation was reproduced - through unequal instruction related to cultural or educational values in modern society. Thus, Bourdieu introduced social capital to conceptualize this difference at an ideological and symbolic level, perceiving that this issue could not be judged merely through the possession or nonpossession of physical capital. Consequently, Bourdieu found that differentiation resulted from the values or operating principles of the democratic system, which prohibited the open class and generational transfer of capital. Thus, he argued that cultural and social capital in modern democratic systems represent camouflaged paths for the class and generational transfer of economic capital.

Micro Perspective of Social Capital. In contrast to Bourdieu, Coleman and Putnam saw social capital theories from a micro perspective. Bourdieu did not include the origin and effect of social capital, whereas Coleman (1990) included the effect and function of social capital in defining social capital. Thus, Coleman defined social capital through the comparison of social capital and physical or human capital. Coleman dealt with social capital in terms of comprehensive and social interactions. In contrast, Putnam stressed the application of social capital.

Robert Putnam has been described as the most influential academic in the world today because he has greatly contributed to advancing the concept of social capital, provided several scales to measure social capital, and also highlighted social capital as an 
important factor for economic development and democracy. With the publication Making Democracy Work (Putnam, 1993), the notion of social capital began to attract great academic and journalistic attention. Since Putnam's study (1993), social capital has been studied at the macro level. However, although studies of this segment have macroscopic generalization, they have been criticized in that the distribution of social capital is different according to the situation even in the same community (Newton, 1999; Kim, 2009).

Putnam (2000) made a distinction between two kinds of social capital: bonding social capital and bridging social capital. Bonding social capital refers to bringing people together who already know each other with the goal of strengthening the relationships that already exist (Granovetter, 1974); it occurs when people are socializing with each other. On the other hand, bridging social capital brings together people or groups who did no previously know each other. Bridging social capital enhances identity over the whole community and improves reciprocity and norms between communities. Putnam argued that those two kinds of social capital, bonding and bridging, strengthen each other. Therefore, in his view, social capital increases when it is used, and if not used, it is exhausted (Putnam, 1993; Kang, 2003).

Also, Putnam conducted a notable study that explains the relationship between social capital and local government performance using the concept of social capital. Elaborating on the two distinct systems of government in Italy - a monarchic system in the south and a republican system in the north—he notes that "In the North, feudal bonds of personal dependence were weakened; in the South, they were strengthened. In the 
North, the people were citizens; in the South, they were subjects... Collaboration, mutual assistance, civil obligation, and even trust.... were the distinguishing features in the North. The chief virtue in the South, by contrast, was the imposition of hierarchy and order on latent anarchy" (Putnam, 1993: 121-30). As a result, northern Italy has developed faster than southern Italy because the former was better endowed with social capital and the endowments of social capital across Italian territories have persisted across centuries.

In summary, in Bourdieu's view, social capital belongs to individuals, whereas Coleman noted that social capital is created in personal relations. Bourdieu and Coleman considered the individual as the unit of analysis of social capital and they observed that social capital provides competitive advantages to the individual, but the advantages do not necessarily involve positive effects; however, in Putnam's view, community and nation are the unit of analysis of social capital and social capital has a positive effect on communities and nations (Winter, 2000).

\section{Contents and Features of Social Capital}

Dimensions of Social Capital

Discussions among social capital researchers have developed the conceptual configuration of social capital and distinguished the aspects of social capital. Putnam (1995) argued that clarifying the dimensions of social capital is a top priority of his study, as a set of resources rooted in relationships has many different attributes (Nahapiet \& Ghoshal, 1998). 
Scholars (Grotaert \& Bastelater, 2005; Harpham et al., 2002; Upoff, 2000) distinguished two aspects of social capital: structural and cognitive. The structural category involves not only various forms of social organization (e.g., roles, rules, precedents, and procedures), but also a wide variety of networks that contribute to cooperation, and to mutually beneficial collective action. On the other hand, the cognitive category derives from mental processes and includes norms, values, attitudes, and beliefs that contribute to cooperative behavior (Uphoff, 2000: 218).

One model of social capital (Bourdieu, 1993; Coleman, 1988; Putnam, 1993; van Deth, 2008) disaggregated social capital into two aspects: structural and cultural. In the work of Bourdieu, the structural aspects are apparent from his emphasis on "connections" (1993: 33) and in his definition of social capital as "the aggregate of the actual or potential resources which are linked to possession of a durable network of more or less institutionalized relationships of mutual acquaintance and recognition" (1986: 248). The influential works of Coleman and Putnam are also based on conceptualizing social capital as covering both structural and cultural aspects (van Deth, 2008). Here, the structural aspects are referred to as social networks, whereas the cultural aspects are associated with trust and civic norms and values.

Nahapiet and Ghoshal (1998) integrated these different facets to social capital to define social capital in terms of three dimensions and described how each of these dimensions facilitates the creation and exchange of knowledge (Nahapiet \& Ghoshal, 1998: 243). Comprehensively, Nahapiet and Ghoshal (1998) provided three dimensions of social capital: (a) structural, (b) relational, and (c) cognitive. The present study utilizes 
their model for several reasons. Nahapiet and Ghoshal's model integrates many of the social capital facets discussed in previous work. Also, their model is useful for examining social capital at the organizational level (Bolino et al., 2002; Subramaniam et al., 2013). Second, other social capital scholars mainly focus on either the structural or relational aspects of social capital but Nahapiet and Ghoshal also incorporate a cognitive dimension. Third, their model established a relationship between social capital and intellectual capital (i.e., organizational knowledge). Lastly, Nahapiet and Ghoshal's dimension embraces all aspects noted above. For example, concerning structural and cultural aspects, the cultural aspects are divided into (1) trust that is included in the relational dimension, and (2) civic norms and values that are included in the cognitive dimension.

Structural dimension. Structural embeddedness involves the properties of the social system, and of the network of relations as a whole, and describes the impersonal configuration of linkages between people or units (Nahapiet \& Ghoshal, 1998). The structural dimension of social capital refers to the overall pattern of connections between people in an impersonal sense- - that is, who you reach and how you reach them (Burt, 1992). It means the number of relations between one person and others in a network, the extent and features of gaps in relationships among people in a network, and the frequency and density of interactions. This dimension is characterized by network ties and network configuration; the presence of network ties between actors and network configuration are the most important facets of this dimension (Nahapiet \& Ghoshal, 1998: Scott, 1991; Wasserman \& Faust, 1994). Network ties are connections between organizational 
members that facilitate information flows and work as channels for knowledge and resource exchanges (Bolino et al., 2002; Subramaniam et al., 2013). For example, Nahapiet and Ghoshal (1998, p. 252) emphasized that "network ties influence both access to parties for combining and exchanging knowledge and anticipation of values through such exchange." On the other hand, network configuration refers to the overall configuration of the ties and the pattern of linkages. Burt (1992) argued that individuals who have a rich and high level of network in terms of information will have an advantage to access information and facilitate the sharing of such information.

Relational Dimension. In contrast, relational embeddedness describes "the kind of personal relationships people have developed with each other through a history of interactions" (Granovetter, 1992; Nahapiet \& Ghoshal, 1998). This focus of this concept is on the particular relationships in which people engage. That is, the relational dimension refers to "the interpersonal nature of relationships developed over time between people, including friendship, respect, approval, prestige, motive for membership of a network, obligations, trust and a sense of identity with the network" (Subramaniam et al., 2013). Those assets are created and leveraged through relationships, which are described as behavioral and actor bonds as opposed to structural bonds. The central facets of this dimension are trust and trustworthiness (Fukuyama, 1995; Putnam, 1993), norms and sanctions (Coleman, 1990; Putnam, 1995), and obligations and expectations (Burt, 1992; Coleman, 1990; Granovetter, 1985). According to Atkinson and Butcher (2003), many researchers proved that when individuals have a high level of trust, they are more willing to engage in social exchange and to be cooperative and communicative. 
Cognitive Dimension. The third dimension of social capital-the cognitive dimension—refers to resources that provide shared language, shared representations, shared codes, shared narratives, interpretations, and systems of meaning among stakeholders (Cicourel, 1973). These are particularly important in the context of intellectual capital (i.e., organizational knowledge) and essential for information/knowledge exchanges. Shared language includes basic assumptions, subtleties, and acronyms - which capture the nuances and explicit meanings of interactions (Chiu et al., 2006). Shared language also produces a common understanding of collective goals and appropriate conduct in an organization, including what is relevant and acceptable corporate governance behavior. Shared narratives, in general, refer to myths, stories, and metaphors that provide a means for creating, exchanging, and preserving rich sets of meanings (du Toit, 2003; Luscher \& Lewis, 2008). Shared narratives are also important for organizational sense-making. Both shared language and shared narratives are potentially important for coordination and decision making.

\section{Function of Social Capital}

The study of social capital mainly focuses on its positive function, following Putnam's perspective. However, the positive function of social capital works in conjunction with its dysfunction. Social capital can work positively in certain situations, while producing adverse effects in other situations.

Positive Function of Social Capital. Several empirical studies show that the formation of social capital is connected with political and economic performance. Putnam 
(1993) describes the role of social capital empirically through his research on the settlement of a local self-governing system. Putnam proved empirically that there is high correlation between levels of social capital and performance of local government. The positive effects of social capital are bounded solidarity, transaction cost reduction, rule enforcement, enforceable trust, and so forth (Coleman, 1993, Putnam, 1993; Knack, 2002).

The first function of social capital is the effect of transaction cost reduction through trust. Transaction, which is sensitive to trust, includes employment contracts and investments that depend on guarantees from governments and banks. Arrow (2000) argues that most commercial transactions include trust. Putnam (1993) argues that dense social networks enhance trust, reduce transaction cost, and promote economic development as information and innovation are accelerated. In Fukuyama's (1997) view, informal norms reduce transaction costs and contribute to a healthy civil society. That is, the positive function of social capital is to increase productivity and satisfaction based on trust. Second, the function of social capital is potentially an inherent resource in social relationships. Information becomes a basis for action, but obtaining information entails great expense. Knowing an expert on a certain issue can reduce efforts and costs to gain information. Above all, social capital has significance in that it provides the passage of information.

Dysfunction of Social Capital. As the concept of social capital is diverse, the functions of social capital are also very diverse. There are positive functions, but also dysfunction that cannot be ignored. However, positive function and dysfunction of social 
capital work together. Namely, social capital can be useful for a certain person, while it can be harmful to another person (Coleman, 1990). Also, social capital can work positively in a certain situation, while it can produce adverse effects in other situations. Harris (2007) empirically analyzed that bonding social capital can lead to increased corruption. With this study as a basis, it became necessary to investigate social capital with a balanced viewpoint. In fact, although social capital theory is broadly accepted, it has also been critically analyzed.

The dysfunctions of social capital are recognized. The first one is the exclusion of outsiders. Portes (1998) argued that despite the benefits to members of a group, the same strong ties may lead to barring others from access. Free-riding is also a problem. The second dysfunction has potentially negative effects on individual freedom and stimulates group intolerance. Social capital, often necessary for community, accordingly reduces privacy and individual freedom. The third dysfunction is the downward grading of valuations. It is impossible to completely remove the negative effects of social capital. Therefore, the way to use social capital positively and effectively should be considered further in social capital studies.

\section{Relevance of Social Capital}

\section{Criticism of Social Capital}

Researchers have criticized the usefulness and relevance of social capital. The range of this criticism is broad and includes ideological criticisms of social capital and criticism of the concept's theoretical accuracy (Platteau, 1996). The negative effects of social capital are often overlooked because the usefulness of social capital is excessively 
emphasized. Criticism about the concept of social capital originates from its basic limitation: the lack of clarity. The meaning of the concept, in relations between individuals and the community, remains unclear. Exacerbating this lack of clarity are issues such as the lack of a measurement scale (Portes, 1998).

The problems, limitations, and criticisms of social capital are discussed by many scholars (Tarrow, 1996; Portes, 1998; Adler \& Kwon, 2002). In 1998, American Behavioral Scientist published a special issue about the criticism of social capital. In this point, there are problems in that social capital theory based on Putnam is globally expanded by the World Bank.

\section{Applicability of Social Capital}

Social capital theory is developed as an independent study. Nearly all areas of research can assimilate social capital theory. Especially since the 1970s, the crisis of western capitalism and the underdevelopment of developing countries diffused the concept of social capital. In other words, social capital can stabilize social reproduction, which is necessary for development. The spread of social capital involves the intention to enhance depoliticized social capital as the role of civic groups (e.g., local government and NGOs) is emphasized. The concept of social capital reached a level where its application is unlimitedly possible (Evans, 1996; Fine, 2001).

\section{Organizational Performance}

\section{Introduction}

Interest in the performance of government organization is increasing all over the world. Reflecting this trend, in the United State performance evaluation regarding 
government organizations has dramatically increased for over 20 years (Sean et al., 2006). In South Korea, a performance-oriented atmosphere is widely cultivated in government organizations (Kim \& Ahn, 2007). In general, evaluation of performance is motivated by several factors (Behn, 2003). Behn describes eight motivations: to evaluate (how well is this government agency performing?), to control (how can public managers ensure their subordinates are doing the right thing?), to budget (on what programs, people, or projects should government spend the public's money?), to motivate (how can pubic managers motivate line staff, middle managers, nonprofit and for-profit collaborators, stakeholders, and citizens to do the things necessary to improve performance?), to celebrate (what accomplishments are worthy of the important organizational ritual of celebrating success?), to promote (how can public managers convince political superiors, legislators, stakeholders, journalists, and citizens that their agency is doing a good job?), to learn (what is working or not working?), and to improve (what exactly should who do differently to improve performance?). However, notwithstanding the motivations surrounding performance evaluations, the biggest problem with performance evaluation is the lack of a singular evaluation method (Murphy, 1992; Ammons, 1995).

Organizational performance is defined in different ways - depending on the method used to examine an organization and approach and the aims of the evaluation in question. Accordingly, business administration views organizational performance as productivity, profitability, and economical output while approach on performance in public administration is cautious because performance in public administration cannot be 
seen as only economic output. However, recently, an endeavor to improve performance is being made in the area of public administration. Due to this, interest in organizational performance is growing and its range is being expended. Namely, organizational performance is a multi-faceted concept.

Performance is composed of hybrid characteristics; it is difficult to clearly define, although various researchers have attempted to delineate the concept (Brewer \& Selden, 2000). The definition of performance has been expressed as "achieving or achieved results" (Kim \& Ahn, 2007: 1099). However, this definition is differently applied according to the range and subject under study. The definition of organizational performance is diverse and dependent on the perspectives and approaches/methods of the organizations. In the study of organizational performance, the most difficult problem is its definition on a reasonable basis. Consequently, previous related studies do not have a united, general evaluation method or indicators because organizational performance is a multi-faceted concept.

In general, the perspective on organizational performance can be divided into three cases: (1) performance is used as the concept of goal attainment at the same level of organizational effectiveness (Rainey, 1997; Jreisat, 1997; Szilagyi \& Wallace, 1990); (2) performance is used as a subordinate concept of effectiveness (Lim et al., 2005); and (3) performance is considered a superordinate concept (Song et al., 2005; Kim et al., 2004; Ko et al., 2004; Kim et al., 1996; Rogers, 1990). In the case that organizational performance is seen as a superordinate concept, various administrative values (e.g., effectiveness, efficiency, responsiveness, equity, speed, job satisfaction, and job 
commitment) are included in subordinate concepts of performance. The present study will first examine the perspective of performance as a superordinate concept because other subordinate concepts can be included in performance.

In the case of performance as a superordinate concept, the associated subordinate concepts include: efficiency, effectiveness, and fairness as components of performance (Brewer \& Selden, 2000); and efficiency, effectiveness, responsiveness, and fairness (Kim \& Kim, 1996). Moreover, Rogers (1990) provided performance factors such as economy, efficiency, effectiveness, level of service, and responsiveness and Morgan (1984) viewed performance factors as efficiency, effectiveness, equity, and responsiveness. Jones (1983) understood the concept of performance as efficiency, effectiveness, equity, responsiveness, and legitimacy. Ostrom (1975) used four criteriaeffectiveness, equity, efficiency, and responsiveness - to evaluate alternative organizational performance. Therefore, based on this literature review, the present study considers efficiency, effectiveness, responsiveness, and equity as components of organizational performance. The factors of organizational performance provided by public administration scholars are represented in Table 3. 
Table 3: Factors of Organizational Performance provided by scholars

\begin{tabular}{|c|c|c|c|}
\hline Scholars & Components & Scholars & Components \\
\hline Yamada (1982) & $\begin{array}{l}\text { (1) productivity } \\
\text { (2) quality } \\
\text { (3) service } \\
\text { (4) cost }\end{array}$ & Kim, G. (1999) & $\begin{array}{l}\text { (1) efficiency } \\
\text { (2) equity } \\
\text { (3) effectiveness } \\
\text { (4) responsiveness }\end{array}$ \\
\hline Altman (1993) & $\begin{array}{l}\text { (1) efficiency } \\
\text { (2) workload } \\
\text { (3) effectiveness }\end{array}$ & $\begin{array}{l}\text { Butt \& Palmer } \\
\quad(1985)\end{array}$ & $\begin{array}{l}\text { (1) economy } \\
\text { (2) effectiveness } \\
\text { (3) efficiency }\end{array}$ \\
\hline Ostrom (1975) & $\begin{array}{l}\text { (1) efficiency } \\
\text { (2) equity } \\
\text { (3) effectiveness } \\
\text { (4) responsiveness }\end{array}$ & Kim, Y. (1999) & $\begin{array}{l}\text { (1) efficiency } \\
\text { (2) equity } \\
\text { (3) effectiveness } \\
\text { (4) responsiveness }\end{array}$ \\
\hline $\begin{array}{l}\text { Brewer \& } \\
\text { Selden (2000) }\end{array}$ & $\begin{array}{l}\text { (1) efficiency } \\
\text { (2) fairness } \\
\text { (3) effectiveness }\end{array}$ & Epstein (1992) & $\begin{array}{l}\text { (1) revenue } \\
\text { (2) effectiveness } \\
\text { (3) efficiency }\end{array}$ \\
\hline $\begin{array}{l}\text { Usher \& Cornia } \\
\text { (1981) }\end{array}$ & $\begin{array}{l}\text { (1) effort } \\
\text { (2) effectiveness } \\
\text { (3) efficiency } \\
\text { (4) responsiveness }\end{array}$ & Ammons (1995) & $\begin{array}{l}\text { (1) workload } \\
\text { (2) effectiveness } \\
\text { (3) efficiency } \\
\text { (4) productivity }\end{array}$ \\
\hline $\begin{array}{c}\text { Brudney \& } \\
\text { England (1982) }\end{array}$ & $\begin{array}{l}\text { (1) efficiency } \\
\text { (2) effectiveness } \\
\text { (3) equity } \\
\text { (4) responsiveness }\end{array}$ & Kim \& Kim & $\begin{array}{l}\text { (1) efficiency } \\
\text { (2) equity } \\
\text { (3) effectiveness } \\
\text { (4) responsiveness }\end{array}$ \\
\hline Jones (1983) & $\begin{array}{l}\text { (1) efficiency } \\
\text { (2) equity } \\
\text { (3) fairness } \\
\text { (4) effectiveness } \\
\text { (5) responsiveness }\end{array}$ & Rogers (1990) & $\begin{array}{l}\text { (1) economy } \\
\text { (2) effectiveness } \\
\text { (3) take-up } \\
\text { (4) efficiency } \\
\text { (5) service level }\end{array}$ \\
\hline Morgan (1984) & $\begin{array}{l}\text { (1) efficiency } \\
\text { (2) equity } \\
\text { (3) effectiveness } \\
\text { (4) responsiveness }\end{array}$ & $\begin{array}{l}\text { Fried \& } \\
\text { Rabinovits (1982) }\end{array}$ & $\begin{array}{l}\text { (1) integrity \& } \\
\text { human right } \\
\text { (2) responsiveness } \\
\text { (3) effectiveness }\end{array}$ \\
\hline
\end{tabular}




\section{Efficiency}

First, efficiency is the output per input or ratio of input to output, and saving on personal expenses and wasteful budget are included in efficiency (Ammons, 1996; Epstein, 1992; Rogers, 1990; Yun, 2005). Also, efficiency in public administration includes the necessary cost for output and the ratio of available resources, provided public goods, and public service (Ammons, 1996; Rogers, 1990). For example, the maximum useful output is gained from the resources devoted to each activity that only minimum level of resources is devoted to achieving a given level of output (Ball, 1998). Namely, efficiency is increased if either lower costs were used to produce a given amount of output, or a given level of cost resulted in increased output. The concept of efficiency reappears often in examinations of performance when emphasizing quantitative aspects; In particular, business process time reduction, business process cost cutting, and accuracy of business process can be included in efficiency.

\section{Effectiveness}

Second, effectiveness in general is defined as goal achievement (Kim, 2005). Most scholars in public administration agree that the concept of effectiveness is "organizational goal achievement" (Min, 2003). However, the operational definition differs in accordance

with research purposes and targets to measure organizational effectiveness. Effectiveness, as well as performance, is a term that is defined according to diverse aspects.

Effectiveness is closely connected with performance (Kim \& Ahn, 2007; Ball, 1998). A succinct outline of the difference between efficiency and effectiveness is that effectiveness is 'doing the right things,' while efficiency is 'doing the thing right' (Ball, 
1998). Conceptual definitions of organizational effectiveness provided by public administration scholars are presented in Table 4.

Table 4: Definitions of Organizational Effectiveness

\begin{tabular}{|l|l|}
\hline Scholar & Conceptual Definition \\
\hline Etzioni (1964) & degree of goal achievement \\
\hline Price (1968) & degree that realistic outcomes achieve original goal \\
\hline Schein (1970) & $\begin{array}{l}\text { survival of the organization, adaptation, maintenance, growth } \\
\text { capability }\end{array}$ \\
\hline $\begin{array}{l}\text { Pfeffer and Salancik } \\
(1978)\end{array}$ & acceptable output and ability to create a behavior \\
\hline Robbins (1983) & short-term and long-term goal achievement \\
\hline $\begin{array}{l}\text { Hodge \& Anthony } \\
\text { (1984) }\end{array}$ & $\begin{array}{l}\text { informal rule and shared norm to create cooperation among } \\
\text { member of society }\end{array}$ \\
\hline Kang (1995) & efficient achievement of objective goal \\
\hline Park (1996) & $\begin{array}{l}\text { to maximize output belonging to organization, mobilizing all } \\
\text { means }\end{array}$ \\
\hline Kim et al. (2000) & $\begin{array}{l}\text { attainment of organizational goal and evaluation criteria of } \\
\text { organization }\end{array}$ \\
\hline
\end{tabular}

In sum, effectiveness is ensuring that the output from any given activity is achieving the desired results. To evaluate effectiveness, it must be established that approved and desired goals are being achieved. A goal may be defined as a concrete expression of a policy objective. However, this is not necessarily a straightforward procedure; some goals may not be initially apparent. Once goals have been established, it should be determined whether these goals are being accomplished (Butt \& Palmer, 1985).

If measuring organizational effectiveness along with performance, perceptions of organization members tends to be measured (Evan, 1993; Robbins, 1990). Most studies measure subjective perception such as job satisfaction and job commitment. 


\section{Responsiveness}

Third, the term responsiveness has been defined as "quick to respond or react appropriately or sympathetically; sensitive" (Stivers, 1994: 365). In public administration, responsiveness refers to reaction of bureaucrats to the needs and preferences of clients related to policy or administration. Recently, customer-oriented administrative services that governments provide aim to improve responsiveness. That is, responsiveness means "to what extent citizens have a benefit related to their needs, preference, and value from administrators and administrative organizations' and to what extent the benefit satisfies citizens' needs" (Yoon, 2000: 2).

Responsiveness is a problematic concept in public administration (Stivers, 1994). In a democracy, administrators are required to be responsive to the popular will. According to Stivers (1994), administrators tend to "treat responsiveness as at best a necessary evil that appears to compromise professional effectiveness, and at worst an indication of political expediency if not outright corruption" (364). Although there are conceptual ambiguities and theoretical controversies, responsiveness is an important value among government organizations (Bryer, 2006; Rourke, 1992; Saltzstein, 1992; Stivers, 1994; Yang \& Pandey, 2007). There is no consensus about the appropriate operationalization of responsiveness or the best way to achieve responsiveness. However, there is no doubt that democratic government should be responsive to the public interest. Public responsiveness as an aggregate measure at the organizational level is an important criterion for evaluating government performance. 
Nevertheless, responsiveness as a fundamental aspect of government performance (Fried, 1976; Glaser \& Denhardt, 2000) is rarely considered in current government performance measurement; and, few public administration studies have empirically assessed the factors that determine government organizations' public responsiveness. The present study considers responsiveness — as a factor of organizational performance - to be a reflection of citizen's desires, customer satisfaction, and addressed client demands in a timely manner.

\section{Equity}

Fourth, equity, or more precisely inequity, is a pervasive concern among industry, labor, and government. Equity is defined as justice, and inequity is defined as injustice. Inequity exists for an individual when he or she perceives an imbalance in the ratio between outcomes (reward for work) and inputs (efforts at work) as other workers' outputs and incomes (Miner, 1980). Adams (1965) defines inequity as "inequity exists for person whenever he perceives that the ratio of his outcomes to inputs and the ratio of others outcomes to others inputs are unequal" (280). Yet, its psychological basis is not fully understood (Adams, 1963). According to Adams's equity theory, equity is balancing employee inputs and outputs. In other words, Adams' equity theory calls for a fair balance to be struck between an employee's inputs (e.g., hard work, skill level, tolerance, and enthusiasm) and an employee's outputs (e.g., salary, benefits, and intangibles such as recognition). It is important to consider Adams' equity theory to improve an employee's job satisfaction and motivation level, and to measure equity as a factor of organizational performance. 
Equity is conceptualized as a combination of various elements. There are three main components of equity: distributive, procedural, and interactional equity. Distributive equity concerns the allocation among stakeholders of costs, risks, and benefits.

Distributive equity is characterized as fairness in the distribution of resources and decision outcomes. The resources or outcomes can be tangible (pay) or intangible (praise) (Adams, 1965). Adams suggested that equity theory can determine the fairness of an outcome and explain employee behaviors caused by perceptions of unfairness (Adams, 1963, 1965). Procedural equity refers to fairness in the political processes that allocate resources and resolve disputes. It involves representation, recognition, voice, and participation in decision-making. If employees were given a chance to participate in the process used to reach outcomes then they might perceive the outcomes as fair (Thibaut \& Walker, 1975). Interactional equity refers to human relations among members of an organization - whether the relationship is fair or not. Interactional equity focuses on employees' perceptions of the interpersonal behavior exercised during the representation of decisions and procedures. It involves various socially sensitive actions, such as when supervisors respond to employees with dignity and respect (Skarlicki \& Folger, 1997). Interactional equity includes interpersonal and informational equity (Adams, 1965; Bies \& Moag, 1986; Leventhal, 1980). Organizational equity is related to the workplace, and employees of an organization will reflect positive behaviors and productivity if they perceive their organization to be fair and just in its procedures, policies, interactions, and distribution systems. 


\section{Social Capital and Organizational Performance}

The facets of social capital have a direct impact on the ability of individuals to combine knowledge in the creation of intellectual capital within an organization (Nahapiet \& Ghoshal, 1998). Social capital has a positive influence on improving organizational productivity (Andrew, 2010; Behn, 1995; Boix \& Posner, 1998; Coleman, 1988; Putnam, 1993). Social capital exists in relations among actors (Coleman, 1988); the relationships are created and sustained through exchange, and in turn, social capital facilitates exchange. When social capital is created in an organization, organizational vitality can be increased to improve organizational performance. Social capital, which is created and sustained through trust and the exchange of networks between individuals, presents a cyclic process that facilitates exchange. That is, when members of an organization have confidence in each other, they are more willing to engage in corporative activities that can generate more trust (Fukuyama, 1995; Putnam, 1993; Nahapiet \& Ghoshal, 1998). The facets of social capital (e.g., trust, norms, and networks) facilitate activities among members within an organization; in turn, the problem solving ability of the organization is improved (Nahapiet \& Ghoshal, 1998).

Researchers have identified a positive relationship between social capital and performance for governments at local, state, and national levels (Booth \& Richard, 1998; Cusack, 1999; Putnam, 1993; Rice, 2001; Rice \& Sumberg, 1997). Trust, as one factor of social capital, plays a role as the basis for participation of learning activities and exchange of knowledge and information (Fukuyama, 1995; Kim \& Lee, 2000; Kim, 1999; Lee, 1996). In the case when the interrelationship is not based on trust, it is 
difficult to exchange and deliver knowledge (Misztal, 1996). Trust facilitates

participation in the exchange of knowledge and information, creation of knowledge, and motivation for participation in knowledge creation. The existence of networks influences the development of intellectual capital as it contributes to participating in exchange of knowledge and learning action. Also, the formation of networks promotes communication of information and knowledge. The co-operational relation brings out efficiency in organizational accomplishment.

Coleman (1988) viewed social capital, as well as physical capital and human capital, as necessary factors to lead productive action. Social capital based on trust of relationship among doers contributes to promote productive action —although it is not concrete - while physical capital and human capital are tangible. For example, a group with strong trust and beliefs can attain better performance than a group lacking these (Coleman, 1998). Also, Boix and Posner (1998) argued that trust between participants increases efficiency of economy. Social capital brings out government efficacy as social capital reduces the costs of enforcing and implementing governmental policies and regulations (Boix \& Posner, 1998). The role of social capital is emphasized in reducing transaction costs in the arena of citizen-government.

According to Behn (1995), mistrust in public management strengthens regulations and rules, which decrease performance. As indicated in Putnam's definition of social capital (i.e., "features of social organization, such as trust, norms, and networks, that can improve the efficiency of society by facilitating coordinated actions"), he also found that social capital is related to public administrative performance. Similar to 
Putnam's conclusion, Tocqueville (1984) expressed that strong norms of social trust and high level of civic participation influence a nation's prospects for effective and responsive self-government.

The formation and creation of social capital can significantly influence organizational performance. The relationships between the three dimensions of social capital and organizational performance will now be described in greater detail. Social capital comprises the structural (networks and connections among actors), relational (trust between actors), and cognitive (values and shared norms among actors) dimensions of the relationships between organization members (Andrew, 2010; Nahapiet \& Ghoshal, 1998; Subramaniam, Stewrt, Ng, \& Shulman, 2013). Each of these dimensions of social capital is a powerful force for improving organizational outcomes by facilitating transactions that result in knowledge diffusion and collective action (Andrews, 2010). A growing number of empirical studies have examined the relationship between organizational social capital and performance using multivariate statistical techniques (e.g., Andrews, 2010; Langbein \& Jorstad, 2004; Leana \& Pil, 2006). These studies found that high levels of social capital are related to better organizational outcomes. For example, Andrew's analysis indicated that cognitive and relational dimensions of social capital are positively related to performance. Andrew (2010) conducted a study dealing with the panel dataset between 2002 and 2005, which consists of 136 English single and upper tier local governments (country councils, London boroughs, metropolitan districts and unitary authorities). 
In a study by Leana and Pil (2006), their results showed that an aggregated measure of structural, relational and cognitive social capital has a positive impact on student test scores. They examined social capital and its relationship with performance at the organizational level in 88 urban public schools. Also, Nahapiet and Ghoshal (1998) argued that social capital comprises three distinct (though interrelated) dimensions that can positively influence organizational outcomes. Each of these dimensions furnishes organization members with collectively-owned assets (Andrews, 2010; Nahapiet \& Ghoshal, 1998). Therefore, the first hypothesis of the present study is that:

H1: Organizational level social capital in a public sector organization will have a positive influence on its organizational performance.

\section{Structural Social Capital and Organizational Performance}

Structural social capital refers to the presence or absence of a network enabling access to people and resources, and it comprises the impersonal configuration of linkages between people or units (Nahapiet \& Ghoshal, 1998: 244). The linkages and connections among persons within an organization enable them to access peers with relevant sets of knowledge or expertise. For instance, according to Kogut and Zander (1996), frequent interactions among organization members in different functional areas and departments is likely to positively influence the speed of organizational learning. Miller (1992) argued that frequent, repeated, and successful interactions between actors increases cooperation rates, which, in turn, can positively influence organizational performance. 
Therefore, the existence of formal and informal networks between actors enhances organizational outcomes (Scott, 1999). Moreover, the creation and formation of network linkages between actors within organizations influences the creation of trust and shared norms, which, in turn, motivate them to participate in social interactions and the exchange of knowledge. The formation of networks within an organization facilitates the delivery and share of information and knowledge, and plays a positive role in encouraging the participation of organization members in knowledge creation (Krackhardt, 1992). Networking comprises formal and informal processes in which cooperative relations are constructed and sustained under the expectation that the relationships with — not only immediate superiors and subordinates, but also — other people help one perform his or her duty. In other words, the cooperative relations among organization members (e.g., collaboration and coordination within organizations) can bring efficiency in performing their duties. The cooperative and collaborative relations across internal boundaries can benefit nearly all organizations (Andrews, 2010). When interaction between different departments within an organization is encouraged, it is possible to access information and knowledge, and to accomplish collective goals or obtain scarce resources (Willem \& Scarborough, 2006). Therefore, it is expected that:

H1-1: A public sector organization with higher levels of structural social capital is more likely to achieve higher levels of organizational performance.

\section{Relational Social Capital and Organizational Performance}

In the relational dimension of social capital, trust is considered the key element of social capital. Many social capital scholars have emphasized the importance of social 
trust (Coleman, 1988; Fukuyama, 1995; Leana \& Van Buren, 1999; Putnam, 1993). Trust as an indicator of social cohesion and solidarity plays an important role in the exchange and sharing of knowledge and information, and participation in learning activities. If mutual relations are not based on trust, it is difficult to exchange and deliver knowledge and information. That is, when people who can trust others are more trustworthy, they are more likely cooperate with others (Brewer, 2003).

Researchers have found that high levels of social trust are related to a variety of desirable outcomes. As mentioned above, Coleman (1988) found that social capital based on trust contributes to improving productivity. Boix and Posner (1998) argued that reciprocal trust improves efficiency of economy, and it functions the same for the public servants of governments. The high levels of relational social capital based on trust between public servants in an organization increase mutual cooperation and facilitate good communication and conversation among other departments. Also, high levels of trust between organizational leaders and members may allow them to exchange important and sensitive information that is not possible in a context of mistrust. Behn (1995) underscored the trust issue of the three important problems ${ }^{6}$ that directors and scholars in public management areas aim to solve. According to Behn, mistrust between organization members causes an increase in regulations and rules, which, in turn, reduces performance. These low levels of performance, in turn, trigger mistrust. Here, mistrust not only decreases organizational performance and effectiveness, but also brings about

\footnotetext{
${ }^{6}$ Behn (1995) suggested three prescriptive questions: (1) the micromanagement question, (2) the motivation question, and (3) the measurement question. Of these, the micromanagement issue is defined by the trust, governance, and enterprise question. Behn indicated that regarding the trust question, how can mistrust between the legislative and administrative branch be resolved.
} 
public mistrust in government—caused by unnecessary and excessive regulation. Moreover, Willem and Buelens (2007) found that high levels of trust in public sector organizations increases bureaucratic efficiency and effectiveness as managers at different organizational levels exchange ideas and information.

Similarly, Cunningham and MacGregor (2000) argued that in a high trust environment, positive intra-organizational relations among organization members engender better employee performance. In addition to that, more recently, Bandiera et al. (2008) analyzed the formation and consequences of social capital between co-workers, and found that friendship ties among workers affect productivity. Strong relational ties reduce turnover intention and rates and increase organizational commitment, which, in turn, bring about better outcomes (Andrew, 2010). As a result, it is anticipated that:

H1-2: A public sector organization within higher levels of relational social capital is more likely to achieve higher levels of organizational performance.

\section{Cognitive Social Capital and Organizational Performance}

Finally, cognitive social capital includes the broader organizational mission, values, and objectives, which are essential for information/knowledge exchanges and collective action. Cognitive social capital differs from relational social capital in that "it relates to the extent to which subjective interpretations of organizational values and goals rather than fillings of trust are shared by the many actors within a given organization" (Andrew, 2010: 587). Such shared values and goals enable organization members to have 
the same understanding, and sharing the perception regarding social situations contributes to the problem solving of organizations. For example, Coleman (1994) argued that if organization members have a common strategic vision and goals, it promotes integration and collective responsibility. That is, shared interpretations of the values and mission of the organization enable organization members to cope with environmental uncertainty for organizational performance (Andrew, 2010; Scott, 2001). As organization members share and pursue a group mission and value, it facilitates communication among members and prediction of other members' behaviors. Facilitating communication among organization members, in turn, forms the basis for cooperation and sharing of information. When the behaviors of members can be predicted, there is a basis for the improvement of trust among members, which, in turn, brings about a positive impact on organizational performance. This is especially important in large organizations, because leaders must communicate with diverse groups of employees and motivate them to achieve desired goals (Selznick, 1957). Thus, it is expected that:

H1-3: A public sector organization within higher levels of cognitive social capital is more likely to achieve higher levels of organizational performance.

\section{Moderating Influence of Cultures}

Numerous studies have shown that social capital (i.e., trust, networks, and the norm of reciprocity) can influence performance (Andrew, 2010; Behn, 1995; Boix \& Posner, 1998; Coleman, 1988; Putnam, 1993). However, studies on social capital and organizational performance overlook the effect of cultural differences between countries 
on how social capital is related to organizational performance. These studies do account for country-specific contexts that influence the relation between social capital and performance in government organizations. The next step in enhancing our understanding of the effects of social capital is to examine how it is affected by national culture. The effect of social capital on organizational performance might differ because the countries have different cultural values regarding power distance, uncertainty avoidance, individualism, masculinity, and long-term orientation.

According to Grimmelikhuijsen et al. (2013), national cultural values play a significant role in how people perceive and appreciate government transparency and trust. Nevertheless, what is less understood is how cultural differences among countries affect the relationship between social capital and organizational performance. Prior work by Hofstede (2001) on the link between culture and trust demonstrates that levels of trust vary among countries depending on their cultural values regarding power distance, uncertainty avoidance, individualism, masculinity, and long-term orientation.

National culture is an important driver of the way people think and act in any given society (Hofstede, 2001). The present study aims to assess the influence of national culture on the relation between organizational level social capital in a public sector organization and organizational performance. The following research question will be central: how does organizational level social capital in a public sector organization influence organizational performance in different cultures?

This study utilizes a cross-country comparison to test whether there are interrelations between social capital and cultural settings. The cross-country comparison 
will be used to compare the influence of national culture in the United States and South Korea. Comparative cross-national research is suitable to test macro hypotheses and to test validated explanations in cultural settings (Lijphart, 1971; Grimmelikhuijsen et al., 2013). Hofstede's work on national culture will be used as a framework for assessing national culture in the United States and South Korea. According to Hofstede's framework, these countries contrast strongly on important cultural characteristics.

The values of Hofstede's cultural indices for the United States and South Korea are presented in Table 5. As shown in Table 5, there are clear cultural deviations between the United States and South Korea. The United States has a lower power distance, low uncertainty avoidance, high individualism, high career success/masculinity, and a shortterm orientation compared to South Korea.

Table 5: Values of Hofstede's Cultural Indices for the United States and South Korea

\begin{tabular}{|l|l|l|l|l|l|}
\hline Country & $\begin{array}{l}\text { Power }^{(1)} \\
\text { Distance }\end{array}$ & $\begin{array}{l}\text { Uncertainty }^{(2)} \\
\text { Avoidance }\end{array}$ & $\begin{array}{l}\text { Individualism }^{(3)} \\
\text { Collectivism }\end{array}$ & $\begin{array}{l}\text { Masculinity }^{(4)} \\
\text { Femininity }\end{array}$ & $\begin{array}{l}\text { Confucian }^{(5)} \\
\text { Dynamism }\end{array}$ \\
\hline U.S. A & 40 & 46 & 91 & 62 & 29 \\
\hline S. Korea & 60 & 85 & 18 & 39 & 75 \\
\hline Mean & 52 & 65 & 50 & 50 & \\
Std. & 20 & 24 & 25 & 20 & \\
Deviation & $11-104$ & $8-112$ & $12-91$ & $5-95$ & \\
Range & & & & & \\
\hline
\end{tabular}

(1) High Number - Large Power Distance

(2) High Number - High Uncertainty Avoidance

(3) High Number - Individualist

(4) Career Success (Masculine) / Quality of Life (Feminine) - High Number - Masculine

(5) High Number - Future Orientation (Dynamism); Low Number - Present \& Past Orientation (Confucian) 


\section{Hofstede's Dimensions of Culture}

Hofstede defined national culture as "the collective programming of the mind that distinguishes the members of one group or category of people from another" (Hofstede, 2001, p. 9). What personality is to an individual, national culture is to a human collectivity. Namely, personality determines the uniqueness of a human group (Hofstede, 2001). Between 1968 and 1973, Hofstede conducted extensive research on the dimensions that constitute national culture examining IBM employees from more than 70 countries (Hofstede, 2001). Hofstede (1983) concluded that there are significant differences in the behavior and attitudes of employees between countries.

Hofstede's cultural dimensions - as a framework for cross-cultural communication - describe the effects of a society's culture on the values of its members, and how these values relate to behavior. Hofstede (2001) analyzed the results of a large database of cultural statistics and found clear patterns of similarity and difference amid the responses along these five dimensions. The five dimensions are power distance, uncertainty avoidance, individualism, masculinity, and long-term orientation. Table 6 presents Hofstede's cultural dimensions defined. 
Table 6: Hofstede's Cultural Dimensions Defined

\begin{tabular}{|l|l|}
\hline Hofstede's Dimension & Definition \\
\hline Power Distance & $\begin{array}{l}\text { The extent to which the less powerful members of } \\
\text { institutions and organizations within a country expect and } \\
\text { accept that power is distributed unequally (Hofstede \& } \\
\text { Hofstede, 2005). }\end{array}$ \\
\hline Uncertainty Avoidance & $\begin{array}{l}\text { The extent to which people in a given culture prefer } \\
\text { structured situations with clear rules over unstructured ones } \\
\text { (Hofstede, 2001). }\end{array}$ \\
\hline $\begin{array}{l}\text { Individualism/ } \\
\text { Collectivism }\end{array}$ & $\begin{array}{l}\text { The degree to which individuals are supposed to look after } \\
\text { themselves or remain integrated into groups (Hofstede, } \\
\text { 2001). }\end{array}$ \\
\hline Masculinity/ & $\begin{array}{l}\text { The distribution of gender roles between women and men } \\
\text { (Hofstede, 2001); Masculine roles (assertiveness, } \\
\text { competition, and achievement) vs. feminine roles (e.g., } \\
\text { solidarity, people, quality of life). }\end{array}$ \\
\hline $\begin{array}{l}\text { Long-term / } \\
\text { Short-term Orientation }\end{array}$ & $\begin{array}{l}\text { The extent to which a culture programs its members to } \\
\text { accept delayed gratification of their material, social, and } \\
\text { emotional needs (Hofstede, 2001). }\end{array}$ \\
\hline
\end{tabular}

The dimensions listed here provide a useful and well-established framework for comparing cultures; the work of Hofstede has been influential in this area of research (Grimmelikhuijsen et al., 2013). Nevertheless, several reviewers note that Hofstede's work has limitations. In terms of his methodology, the surveys were administered to employees of an international company, IBM (Goodstein, 1981; Hunt, 1981;

Grimmelikhuijsen et al., 2013), and only countries where IBM was established were included. In addition to this, a second major criticism is a potentially outdated set of data due to ongoing globalization and convergence of values between societies (Fernandez et al., 1997; Gooderham \& Nordhaug, 2001; Grimmelikhuijsen et al., 2013). 
Hofstede's framework for the diagnosis of culture is, at present, the most established in the literature supported by elaborate empirical research. His findings have been confirmed through many replication studies (Grimmelikhuijsen et al., 2013; Yoo et al., 2011). Accordingly, Hofstede's work is the most cited and used by scholars who are involved in cross-cultural research. As a result, his framework is still relevant and applicable in many recent studies that use culture to explain the differences in international management behavior.

Hofstede's framework has been popular for several reasons. First, its cultural dimensions fully cover and extend major conceptualizations of culture developed through decades. Second, Hofstede's dimensions were empirically developed. Third, social science and cross-cultural studies have heavily replicated Hofstede's typology (Yoo et al., 2011). These well-known dimensions have been widely accepted and applied in cross-cultural studies (Grimmelikhuijsen et al., 2013; Yoo et al., 2011). Therefore, the present study uses Hofstede's dimensions of culture as a framework to compare the United States and South Korea.

\section{Power Distance}

The dimension of power distance concerns degree of power inequality and is related to different solutions to the basic problem of human inequality. A high power distance means that society accepts unequal distribution of power. Low power distance means that power is shared and well dispersed, and that society-members view themselves as equals. Large power distance societies are characterized by centralized 
authority, autocratic leadership, paternalistic management style, strong hierarchies, large number of supervisory staff, and an expectation of inequality and power differences. However, the characteristics of small power distance societies are decentralized authority and decision making responsibility, flatter organizational structures, consultative or participative management style, small proportion supervisory staff, lack of acceptance and questioning of authority, rights consciousness, and tendency toward egalitarianism.

\section{Uncertainty Avoidance}

Uncertainty avoidance is related to the level of anxiety and stress in a society that society members feel in uncertain or unknown situations, both current and in the future. Strong uncertainty avoidance includes dodging ambiguous situations whenever possible. High uncertainty avoidance scoring nations are governed by rules and order, whereas low uncertainty avoidance scores indicate that the society enjoys novel events and values difference. Weak uncertainty is characterized by accepting change and risk, tolerance of differing behaviors and opinions, flexibility, informal business attitude, and organizations with a relatively low degree of structure and few rules, and promotions based on merit. On the other hand, strong uncertainty avoidance is characterized by avoidance of risk, lack of tolerance for deviants, strong need for consensus, and need for predictabilityhence, planning is important, along with respect for authority.

\section{Individualism/Collectivism}

Individualism is related to the integration of individuals into primary groups and refers to the strength of the ties people have to others within the community. A high 
individualism score indicates loose connections, while a society with a low individualism score has strong group cohesion. There are differences between individualistic cultures and collectivistic cultures. Individualistic cultures foster contractual relationships that are based on the principles of exchange. They calculate profit and loss before engaging in a behavior. These cultures focus on the self - or at most on close loved ones—and are concerned with the relationship between their behaviors and their own needs, interests and, goals. Also, individualistic cultures emphasize pleasure, fun, and personal enjoyment more than the social norms and duties belonging to many in-groups that exert little influence on their lives. On the other hand, collectivistic cultures behave according to social norms that are designed to maintain social harmony among members of the ingroup; collectivistic cultures consider the implications of their actions on the wider collective. These cultures are very concerned about in-group members and are indifferent or hostile toward out-group members. Also, they emphasize hierarchy and harmony within group and regulate behavior through group norms.

\section{Masculinity/Femininity or Career Success and Quality of Life}

Masculinity is related to the division of emotional roles between men and women and refers to how much a society adheres to, and values, traditional male and female roles. The characteristics of high masculinity are that men are masculine and women are feminine; therefore, there is a well-defined distinction between men's work and women's work. That is, gender roles are clearly distinct. In regard to career success (masculine) cultures, men are supposed to be assertive, tough, and focused on material success. They place importance on the value of mastery of job, nature, and people. On the other hand, in 
quality of life (feminine) cultures, social gender roles overlap. A woman can do anything a man can do, and powerful and successful women are admired and respected. Both men and women are supposed to be modest, tender, and concerned about quality of life. They emphasize non-materialistic aspects of success.

\section{Long-term Orientation}

Long-term orientation relates to the decision to focus efforts on the future or the present. This is the fifth dimension that Hofstede added in the 1990s, after finding that Asian countries with a strong link to Confucian philosophy acted differently from Western cultures. Long-term cultures view the world in a predictable manner and presume that things develop in a predictable manner, and reflect a dynamic, future-

oriented mentality. They emphasize persistence, thriftiness, having a sense of shame, and ordering relationships based on status and observing this order. The characteristics of high, long-term orientation are that family is the basis of society, parents and men have more authority than young people and women, and high value is placed on education and training. On the other hand, short-term orientation cultures are characterized by promotion of equality, high creativity, individualism, and orientation toward present and past. They emphasize personal steadiness, stability, protecting face, respect for tradition, and reciprocation of greetings, favors, and gifts.

Prior work by Hofstede (2001) on the link between culture and trust demonstrates that levels of trust vary among countries depending on their cultural values regarding power distance, uncertainty avoidance, individualism, masculinity, and long-term 
orientation. Given that trust is by definition part of social capital, I expect that the effect of social capital on organizational performance will differ across countries based on cultural values. Thus, it is anticipated that:

$H 2$ : The effect of organizational level social capital in a public sector organization on its organizational performance will differ according to the cultures.

\section{Agency Type}

According to organizational theorists, the structure and behavior of institutions is determined by the character of the institution itself, its predominant culture, and the characteristics of the policies they administer (Newman, 1994). Lowi's work (1985) on administrative structure is representative of the approach involving characteristics of policies. That is, Lowi's typology of agencies is based on policy type. Lowi (1964) distinguished between three policy types: distributive policy, redistributive policy, and regulatory policy. Government agencies are charged with the implementations of various polices. Agency types are related to the goals of specific policies, which are in turn reflected in the mission statements of government agencies. The present study concentrates on the first three models - the fourth agency model is not immediately relevant to this study, as it focuses on boundary and jurisdictional issues rather than on functional or policy content (Lowi, 1972; Newman, 1994; Wright, 1988). Lowi's policy topology has been used as a theoretical basis by many public administration scholars (Gooderham \& Nordhaug, 2001; Leana \& Pil, 2006; Newman, 1994; Sanders, 1990; Yoo et al., 2011). 


\section{Regulatory Agencies}

Regulatory agencies are responsible for implementing and enforcing specific laws, formulating and implementing rules imposing obligations on individuals, and providing sanction for nonconformance (Lowi, 1985). Regulation is a coercive process by definition, one of several ways that governments seek to control society and individual conduct (Lowi, 1972) and the means by which a regulatory agency implements laws enacted by the legislature. Concentrated costs are involved in implementing regulatory policies, and its benefits are marginal and widely dispersed (Neman, 1994; Wright, 1988). Regulatory agencies in Omaha and Wonju include Permits and Inspections, Housing and Community Development, Urban Planning, Traffic Administration, Architecture, and Construction Accident Prevention. Depending on each department's mission, they are responsible for administration of zoning and subdivision regulations, enforcement of building codes and the minimum dwelling standards ordinance, carrying out ordinances for permits and inspection, and condemning and removing hazardous buildings.

\section{Distributive Agencies}

Distributive agencies are responsible for distributing tangible benefits and intangible ones, such as research outputs, information, distributive public goods, and insurance benefits. Distributive agencies attempt to promote socially desired activities by providing subsidies. Distributive agencies, as defined by Lowi, are (nearly) the antithesis of regulatory agencies in terms of mission. In other words, both agencies are responsible for polices that work directly on or though individuals, but the relation is one of patron 
and client rather than controller and controlled (Newman, 1994). As a result, "distributive agencies can operate in their political environment almost as though they had unlimited resources" (Lowi, 1985: 87). Distributive agencies produce only winners, not losers, and involve a high degree of cooperation and mutually rewarding logrolling (Wright, 1988). Distributive agencies in Omaha and Wonju include Public Works, Health and Physical Educations, Parks, and Information and Communication. Their mission is to effectively meet the environmental quality needs of citizens. These departments offer many of the basic services that affect the daily lives of all who live and work in the designated city. The main responsibilities of the departments are the design, construction, and maintenance of the city's infrastructure.

\section{Redistributive Agencies}

Redistributive agencies are responsible for redistributing benefits to one group of people (e.g., poor and unemployed) by taxing another group of people (e.g., rich and employed). That is, redistributive policies and programs aim to manipulate the allocation of wealth, property, and rights among social classes or racial groups in society (Riply \& Frankin, 1987). Social welfare programs are commonly identified as redistributive in terms of intent and impact (Wright, 1988). Redistributive agencies in Omaha and Wonju include Human Rights and Relations, Human Resources, Welfare Policy, Livelihood Security, and Women and Family, which are categorized by their responsibilities and missions. These departments are charged with civil rights enforcement, contact compliance, and community relations/discrimination prevention. They are responsible for the investigation, elimination, and prevention of all forms of prohibited discrimination, 
including that based on race, creed, color, religion, gender, national origin, age, disability, or any other form of discrimination proscribed by ordinance or resolution and one appointed council: the Economic Inclusion Council. Their goal is to ensure equal opportunity and treatment for all citizens of the city.

Each of the agency types has its own political structure, political process, elite, and group relations (Lowi, 1964), and each has different responsibilities and missions. According to Newman (1994), the work environment of each of Lowi's agency types is distinctive and predicts leadership styles, and patterns of career advancement. These distinctive features of each agency type will influence social capital, such as trust and networks and organizational performance. Thus, it is expected that:

H3: Within a given culture, social capital and organizational performance in a public sector organization will vary by agency type.

\section{Hypotheses}

The present study proposes the following hypotheses:

Hypothesis 1. Organizational level social capital in a public sector organization will have a positive influence on its organizational performance.

1-1. A public sector organization with higher levels of structural social capital is more likely to achieve higher levels of organizational performance.

1-2. A public sector organization with higher levels of relational social capital is more likely to achieve higher levels of organizational performance. 
1-3. A public sector organization with higher levels of cognitive social capital is more likely to achieve higher levels of organizational performance.

Hypothesis 2 The effect of organizational level social capital in a public sector organization on its organizational performance will differ according to culture.

Hypothesis 3. Within a given culture, social capital and organizational performance in a public sector organization will differ according to agency type.

\section{Summary}

This chapter began by introducing social capital theory—including its academic origins, formation background, dimensions, functions, criticisms, and applicability. Subsequently, the literature on organizational performance was reviewed by describing the factors of organizational performance. This chapter provided a literature review on the relationship between social capital and organizational performance. The literature on culture and agency type was also reviewed. Lastly, based on the literature review, this chapter provided hypotheses at the end of the chapter. 


\section{CHAPTER 3: RESEARCH METHDOLOGY}

This chapter discusses the methodology used in this study to test research hypotheses, including the analysis model and research design, measurement, and methodology such as unit of analysis, sample and data collection, survey instrument, and statistical methods.

\section{Analysis Model}

To analyze the effect of social capital on organizational performance in different cultures, this study selected social capital as a major explanatory variable, organizational performance as a dependent variable, and culture as a moderator variable. Descriptions of how these variables were measured are provided below.

\section{Measuring Social Capital}

Based on the literature review, social capital was operationalized along three

dimensions: structural social capital, relational social capital, and cognitive social capital (Andrew, 2010; Nahapiet \& Ghoshal, 1998; Subramaniam et al., 2013). The structural dimension of social capital was measured by adapting two measures from Miller (1983) and Andrew (2010) for process integration-asking informants about the extent of 'coordination and joint-working' and 'cross-departmental and cross-cutting working' within their organizations. The relational dimension of social capital was measured by interpersonal trust and institutional trust. That is, to measure the relational dimension of 
social capital, the present study asked whether 'there is a high level of trust between topmanagement and staff, local government heads, co-worker, local assembly man, and citizen' and if 'there is a high level of trust between public servant's labor union, local council, community organization, and other departments.' These survey items were developed from those utilized in Cusack's (1999) study of social capital and local government performance and Andrew's (2010) study of organizational social capital, structure and performance. Then, the relational social capital index was created by combining these measures and other measures. The cognitive dimension of social capital was measured based on those used by Tsai and Ghoshal (1998) and Andew (2010). It includes the extent to which the local government's 'mission, values and objectives are clearly and widely owned and understood by all staff' and the extent to which the organization concentrated on achieving its 'mission, values and objectives.' The measurement/survey items are presented in Table 7. 
Table 7: Measurement Items of Social Capital

\begin{tabular}{|l|l|}
\hline & Measurement/Survey Items \\
\hline Structural & $\begin{array}{l}\text { Our department is actively working together and coordinating with } \\
\text { our members. } \\
\text { Our department is coordinating and joint working with other } \\
\text { departments. } \\
\text { Our department has various networks and shares information with } \\
\text { other departments. } \\
\text { Our department is strongly linked by community organizations. }\end{array}$ \\
\hline Socialional Capital & $\begin{array}{l}\text { Our department has a high level of trust in a local government head. } \\
\text { There is a high level of trust between top-management and staff in } \\
\text { our department. } \\
\text { There is a high level of trust among co-workers in our department. } \\
\text { Our department has a high level of trust in local assembly man. } \\
\text { Our department has a relationship of trust with citizens. } \\
\text { Our department has a high level of trust in public servant's labor } \\
\text { union. } \\
\text { Our department has a high level of trust in local council. } \\
\text { Our department has a high level of trust in community organization. } \\
\text { Our department has a high level of trust in other departments. }\end{array}$ \\
\hline $\begin{array}{l}\text { Cognitive } \\
\text { Social Capital }\end{array}$ & $\begin{array}{l}\text { Our department clearly and widely understands the authority's } \\
\text { missions, values and objectives. } \\
\text { Our department thinks that the missions and objectives are valuable. } \\
\text { The objectives of our department are consistent and there is no } \\
\text { conflict with the objectives. } \\
\text { Our department concentrates on achieving its missions, values and } \\
\text { objectives. }\end{array}$ \\
\hline
\end{tabular}

\section{Measuring Organizational Performance}

Organizational performance, in general, is defined as efficiency, effectiveness, responsiveness, and equity. Scholars in public administration commonly regard these as components of organizational performance. Ostrom (1975) used effectiveness, equity, efficiency, and responsiveness as criteria to evaluate alternative organizational performance. Thus, organizational performance was measured as follows: first, efficiency was gauged by business process time reduction, business process cost cutting, accuracy of 
business process, and administrative efficiency improvement. Second, goal attainment, qualitative satisfaction, and quantitative satisfaction were used to assess effectiveness. Third, responsiveness was measured by reflection of client (citizen)'s desires, customer satisfaction, and addressed client demands in a timely manner. Equity was measured with distributive, procedural, and interactional equity. The measurement items of organizational performance are presented in Table 8.

Table 8: Measurement Items of Organizational Performance

\begin{tabular}{|l|l|}
\hline & Measurement/Survey Item \\
\hline Efficiency & $\begin{array}{l}\text { Time in handling the tasks of our department is reduced. } \\
\text { Cost to dealing with tasks of our department is reduced. } \\
\text { Accuracy of business process of our department is improved. } \\
\text { Administrative efficiency of our department is improved. }\end{array}$ \\
\hline Effectiveness & $\begin{array}{l}\text { Planned goal of our department is attained. } \\
\text { The quality of business process of our department is improved. } \\
\text { Business productivity of our department is improved. }\end{array}$ \\
\hline Responsiveness & $\begin{array}{l}\text { Our department continually realizes and promptly reacts to the } \\
\text { demands of client (citizen). } \\
\text { Our department focuses on general customer (citizen) } \\
\text { satisfaction. } \\
\text { Our department understands client demands and addresses these } \\
\text { demands in a timely manner. }\end{array}$ \\
\hline Equity & $\begin{array}{l}\text { The distribution of resources (costs, risks and benefits) resulting } \\
\text { from decision-making within our department is fair with all } \\
\text { staff. } \\
\text { The process for determining the resources within our } \\
\text { department is fair with all staff. } \\
\text { Our department maintains fairness in dealing with human } \\
\text { relationships among staff. }\end{array}$ \\
\hline
\end{tabular}




\section{Measuring Culture}

For culture variables, the present study utilizes Hofstede's five dimensions of culture including power distance, uncertainty avoidance, individualism, masculinity, and long-term orientation. The dimensions provide a useful and well-established framework for comparing cultures. Yet, Hofstede's work has limitations that several reviewers have noted. Despite the criticisms, Hofstede's framework for the diagnosis of culture is, at present, the most established in the literature - supported by elaborate empirical research and is still relevant and applicable in many recent studies (Grimmelikhuijsen et al., 2013; Yoo et al., 2011).

The dimension of power distance concerns the degree of power inequality. A high power distance means that society accepts unequal distribution of power while low power distance means that power is shared. Following this definition, power distance is measured by decision making, opinion, social interaction, agree decision, and delegating important task. Uncertainty avoidance is related to the level of anxiety and stress in a society and strong uncertainty avoidance tries to avoid ambiguous situations whenever possible. Based on this, uncertainty avoidance is measured by the presence of instructions, following instructions and procedures, importance of rules and regulations, standardized work procedures, and importance of instructions for operations. Individualism refers to the strength of the ties among people within the community. Therefore, collectivism/individualism is measured by sacrifice self-interest, whether individuals stick with the group, group welfare, group success, individuals' goals, and group loyalty. Masculinity refers to how much a society values traditional male and female roles. Masculinity/femininity or career success/quality of life is measured by 
professional career, problem solving, solving difficult problems, and jobs between man and woman. Long-term orientation relates to the decision to focus efforts on the future or the present and is measured by thriftiness, persistence, personal steadiness, and stability, long-term planning, giving up today's fun for success, working hard for success in future.

Table 9 shows a 26 -item five dimensional scale of cultural values.

Table 9: Measurement Items of Culture

\begin{tabular}{|c|c|}
\hline & Measurement/Survey Item \\
\hline $\begin{array}{l}\text { Power } \\
\text { Distance }\end{array}$ & $\begin{array}{l}\text { People in higher positions should make most decisions without consulting } \\
\text { people in lower positions. } \\
\text { People in higher positions should not ask the opinions of people in lower } \\
\text { positions too frequently. } \\
\text { People in higher positions should avoid social interaction with people in lower } \\
\text { positions. } \\
\text { People in lower positions should not disagree with decisions by people in } \\
\text { higher positions. } \\
\text { People in higher positions should not delegate important tasks to people in } \\
\text { lower positions. }\end{array}$ \\
\hline $\begin{array}{l}\text { Uncertainty } \\
\text { Avoidance }\end{array}$ & $\begin{array}{l}\text { It is important to have instructions spelled out in detail so that I always know } \\
\text { what I'm expected to do. } \\
\text { It is important to closely follow instructions and procedures. } \\
\text { Rules and regulations are important because they inform me of what is expected } \\
\text { of me. } \\
\text { Standardized work procedures are helpful. } \\
\text { Instructions for operations are important }\end{array}$ \\
\hline Collectivism & $\begin{array}{l}\text { Individuals should sacrifice self-interest for the group. } \\
\text { Individuals should stick with the group even through difficulties. } \\
\text { Group welfare is more important than individual rewards. } \\
\text { Group success is more important than individual success. } \\
\text { Individuals should only pursue their goals after considering the welfare of the } \\
\text { group. } \\
\text { Group loyalty should be encouraged even if individual goals suffer }\end{array}$ \\
\hline $\begin{array}{l}\text { Long-term } \\
\text { Orientation }\end{array}$ & $\begin{array}{l}\text { Careful management of money (Thrift), Going on resolutely in spite of } \\
\text { opposition (Persistence), Personal steadiness and stability, Long-term planning, } \\
\text { Giving up today's fun for success in the future, Working hard for success in the } \\
\text { future }\end{array}$ \\
\hline Masculinity & $\begin{array}{l}\text { It is more important for men to have a professional career than it is for women. } \\
\text { Men usually solve problems with logical analysis; women usually solve } \\
\text { problems with intuition. } \\
\text { Solving difficult problems usually requires an active, forcible approach, which } \\
\text { is typical of men. } \\
\text { There are some jobs that a man can always do better than a woman. }\end{array}$ \\
\hline
\end{tabular}


Accordingly, the present study composed a measurement index. Based on the literature review, a conceptual model was developed—presented in Figure 1.

Figure 1: Conceptual Framework of Factors Affecting Organizational Performance

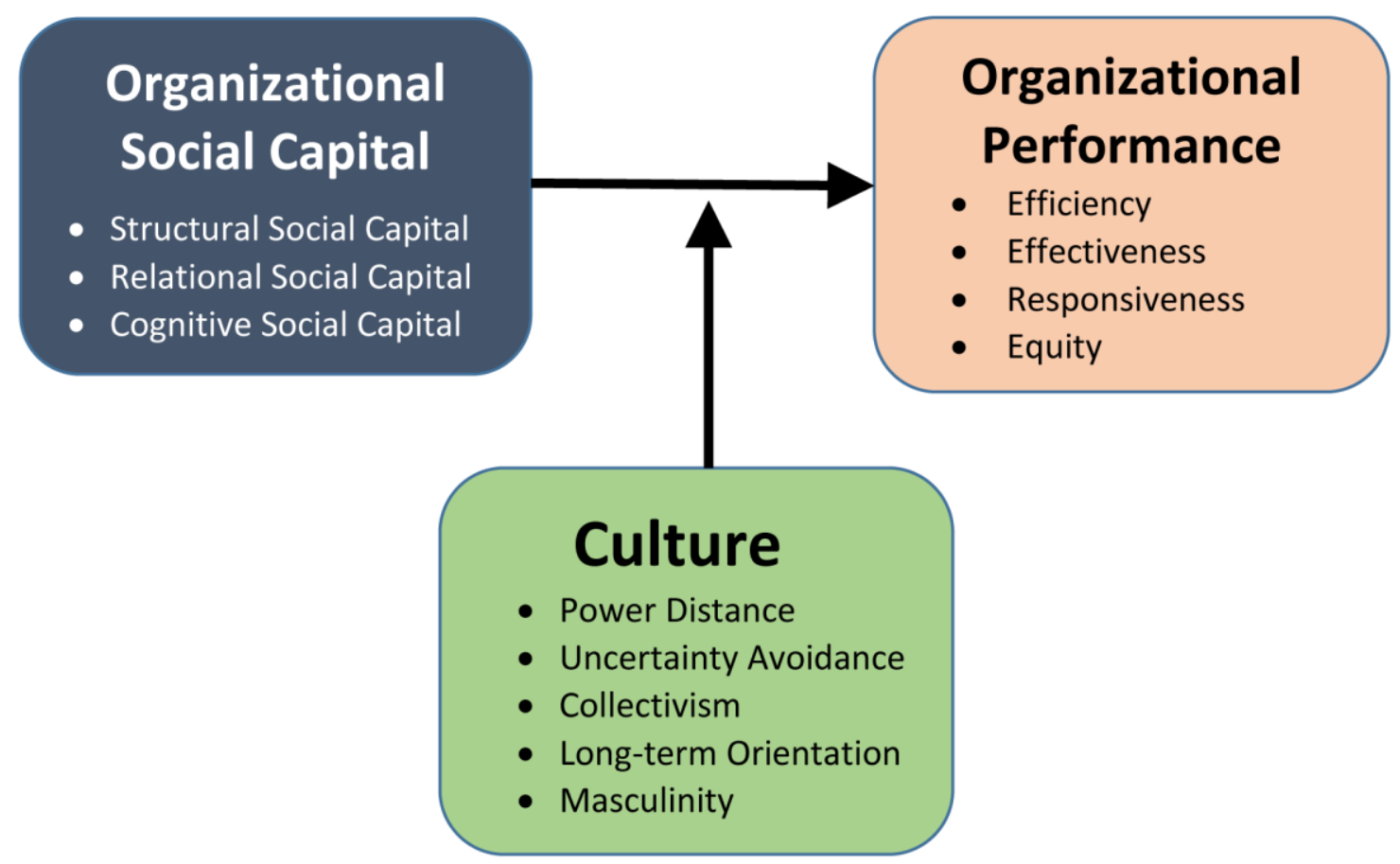

\section{Research Design}

Table 10 presents factors and the measurement index through factor analysis based on the survey questions. First, culture variables consist of 26 measurement indices and 5 factors. The Cronbach's Alpha for culture was .779. Secondly, the independent variable — social capital—consists of 17 measurement indices and 3 factors. The Cronbach's Alpha of social capital variables was .934. Finally, organizational performance as a dependent variable consists of 13 measurement indices and 4 factors. 
The Cronbach's Alpha was .933. Cronbach's Alpha of all variables are over .750 which is acceptable.

Table 10: Factors through Factor Analysis and Measurement Index

\begin{tabular}{|c|c|c|c|c|}
\hline Variable & Factor & Measurement Index & $\begin{array}{l}\text { Cronba } \\
\text { Alpha }\end{array}$ & \\
\hline \multirow[t]{5}{*}{ Culture } & $\begin{array}{l}\text { Power } \\
\text { Distance }\end{array}$ & $\begin{array}{l}\text { decision making, opinion, social } \\
\text { interaction, agree decision, and } \\
\text { delegating important task }\end{array}$ & .750 & \multirow{5}{*}{.779} \\
\hline & $\begin{array}{l}\text { Uncertainty } \\
\text { Avoidance }\end{array}$ & $\begin{array}{l}\text { having instructions, following } \\
\text { instructions and procedures, } \\
\text { importance of rules and } \\
\text { regulations, standardized work } \\
\text { procedures, and importance of } \\
\text { instructions for operations }\end{array}$ & .779 & \\
\hline & Collectivism & $\begin{array}{l}\text { sacrifice self-interest, stick with } \\
\text { the group, group welfare, group } \\
\text { success, and individuals' goal, } \\
\text { group loyalty }\end{array}$ & .801 & \\
\hline & $\begin{array}{l}\text { Long-Term } \\
\text { Orientation }\end{array}$ & $\begin{array}{l}\text { Thrift, persistence, personal } \\
\text { steadiness and stability, long-term } \\
\text { planning, giving up today's fun } \\
\text { for success, working hard for } \\
\text { success in future. }\end{array}$ & .734 & \\
\hline & Masculinity & $\begin{array}{l}\text { professional career, problem } \\
\text { solving, solving difficult } \\
\text { problems, and jobs }\end{array}$ & .854 & \\
\hline \multirow[t]{3}{*}{ Social Capital } & $\begin{array}{l}\text { Structural } \\
\text { social capital }\end{array}$ & $\begin{array}{l}\text { internal co-ordination, external } \\
\text { co-ordination, internal } \\
\text { connectivity, and external } \\
\text { connectivity }\end{array}$ & .806 & \multirow{3}{*}{.934} \\
\hline & $\begin{array}{l}\text { Relational } \\
\text { social capital }\end{array}$ & $\begin{array}{l}\text { Interpersonal trust between local } \\
\text { government head, top- } \\
\text { management and staff, co-worker, } \\
\text { local assembly man, and citizen. }\end{array}$ & .895 & \\
\hline & $\begin{array}{l}\text { Cognitive } \\
\text { social capital }\end{array}$ & $\begin{array}{l}\text { Understanding of mission, values, } \\
\text { and objectives, values of } \\
\text { objectives, conflict with } \\
\text { objectives, and achievement of } \\
\text { objectives. }\end{array}$ & .865 & \\
\hline
\end{tabular}




\begin{tabular}{|c|c|c|c|c|}
\hline \multirow[t]{4}{*}{$\begin{array}{l}\text { Organizational } \\
\text { Performance }\end{array}$} & Efficiency & $\begin{array}{l}\text { Business process time reduction, } \\
\text { business process cost cutting, } \\
\text { accuracy of business process, } \\
\text { administrative efficiency } \\
\text { improvement }\end{array}$ & .876 & \multirow{4}{*}{.933} \\
\hline & Effectiveness & $\begin{array}{l}\text { Goal attainment, qualitative } \\
\text { satisfaction, quantitative } \\
\text { satisfaction }\end{array}$ & .876 & \\
\hline & $\begin{array}{l}\text { Responsivene } \\
\text { SS }\end{array}$ & $\begin{array}{l}\text { Reflection of client (citizen)'s } \\
\text { desire, customer satisfaction, } \\
\text { addressed client demands in a } \\
\text { timely manner }\end{array}$ & .853 & \\
\hline & Equity & $\begin{array}{l}\text { Distributive equity, Procedural } \\
\text { equity, Interactional equity }\end{array}$ & .938 & \\
\hline
\end{tabular}

\section{Methodology}

\section{Unit of Analysis}

Unit of analysis is defined as "the entities (objects or events) under study" (Singleton \& Straits, 2005, p. 45). Clarification of the unit of analysis can prevent the risk of drawing invalid of false conclusions about research findings (Babbie, 2001; Singleton $\&$ Straits, 2005). The present study aims to examine the effect of social capital on organizational performance in different cultures. The unit of analysis is public service organization or department.

\section{Sample and Data Collection}

In order to examine the levels of social capital and the factors affecting organizational performance, a survey was sent to public officials in the city of Omaha, Nebraska, in the United States and Wonju city in South Korea. 


\section{Country Selection}

The United States and South Korea were chosen based on Hofstede's work on national culture. According to Hofstede's framework, these countries contrast strongly on important cultural characteristics. The scores ${ }^{7}$ for national culture between the United States and South Korea are relative. A lower score suggests that a cultural dimension is less pronounced in a particular nation compared to other nations examined. A higher score suggests that a cultural dimension is more pronounced in a particular nation compared to the other nations examined. Scores for the U.S. and South Korea differ significantly on the dimensions of national culture, meaning that there are clear cultural differences between the two countries. In comparison to South Korea, the United States has lower power distance, lower uncertainty avoidance, higher individualism, higher masculinity, and a short-term orientation.

\section{City Selection}

The city of Omaha, Nebraska, in the United States and Wonju city in South Korea were chosen as typical representatives of each country. More specifically, the cities were selected to be as close as possible to the national averages on different criteria, such as percentage of ethnic minorities, education level, income, and sectors of economy. Tables 11 and 12 compare the two cities to the national averages on several criteria.

\footnotetext{
${ }^{7}$ Values of Hofstede's cultural indices for the United States and South Korea were presented in Table 5.
} 
Table 11: City Selection (South Korea)

\begin{tabular}{|c|c|c|c|}
\hline & \multicolumn{2}{|c|}{ South Korea } \\
\hline & Matching Criteria & \multirow{2}{*}{$\begin{array}{r}\text { Whole Korea } \\
932,983\end{array}$} & \multirow{2}{*}{$\begin{array}{r}\text { Wonju city } \\
2,436\end{array}$} \\
\hline By ethnicity & Alien register & & \\
\hline & $\%$ of ethnic minorities & $0.55 \%$ & $1.32 \%$ \\
\hline \multirow{5}{*}{$\begin{array}{l}\text { Education level } \\
\text { (2010) }\end{array}$} & Less than High school & $32.19 \%$ & $34.32 \%$ \\
\hline & High school graduate & $31.20 \%$ & $31.08 \%$ \\
\hline & Some college or associate degree & $11.99 \%$ & $11.51 \%$ \\
\hline & Bachelor's degree & $21.13 \%$ & $20.22 \%$ \\
\hline & $\begin{array}{l}\text { Master's, Doctorate, or Professional } \\
\text { Degree }\end{array}$ & $3.48 \%$ & $2.87 \%$ \\
\hline Income & Average monthly income (2013) & $\begin{array}{r}1,999,157 \\
\text { won }\end{array}$ & $\begin{array}{r}1,574,500 \\
\text { won }\end{array}$ \\
\hline \multirow{3}{*}{$\begin{array}{l}\text { GDP by sector } \\
\text { (2011 est.) }\end{array}$} & Agriculture & $2.77 \%$ & $2.21 \%$ \\
\hline & Industry & $71.49 \%$ & $63.51 \%$ \\
\hline & Services & $25.74 \%$ & $34.28 \%$ \\
\hline GRDP & & $1,274,989,283$ & $5,551,490$ \\
\hline
\end{tabular}

*Source: Race and Sectors of Economy - Korean Statistical Information Service, Income-Statistics Korea, National Pension Service

Table 12: City Selection (The United States)

\begin{tabular}{|l|l|r|r|}
\hline Matching Criteria & \multicolumn{2}{|c|}{ United States } \\
\cline { 3 - 4 } \multicolumn{1}{|l}{ By race } & White & $72.4 \%$ & $73.1 \%$ \\
\cline { 2 - 4 } & African American & $12.6 \%$ & $13.7 \%$ \\
\cline { 2 - 4 } & Asian & $4.8 \%$ & $2.4 \%$ \\
\cline { 2 - 4 } & American Indian and Alaska native & $0.9 \%$ & $0.8 \%$ \\
\cline { 2 - 4 } & Native Hawaiian and Pacific Islander & $0.2 \%$ & $0.1 \%$ \\
\cline { 2 - 4 } & other & $6.2 \%$ & $6.9 \%$ \\
\cline { 2 - 4 } & Multiracial (2 or more) & $2.9 \%$ & $3.0 \%$ \\
\hline \multirow{3}{*}{ By ethnicity } & Hispanic/Latino & $16.3 \%$ & $13.1 \%$ \\
\cline { 2 - 4 } & Non-Hispanic/Latino & $83.7 \%$ & $86.9 \%$ \\
\hline \multirow{2}{*}{$\begin{array}{l}\text { Education level } \\
\text { (ACS 2008- }\end{array}$} & Less than High school & $14.28 \%$ & $11.92 \%$ \\
\cline { 2 - 4 } 2012 data) & High school graduate & $28.24 \%$ & $24.38 \%$ \\
\cline { 2 - 4 } & Some college or associate degree & $28.99 \%$ & $31.23 \%$ \\
\hline
\end{tabular}




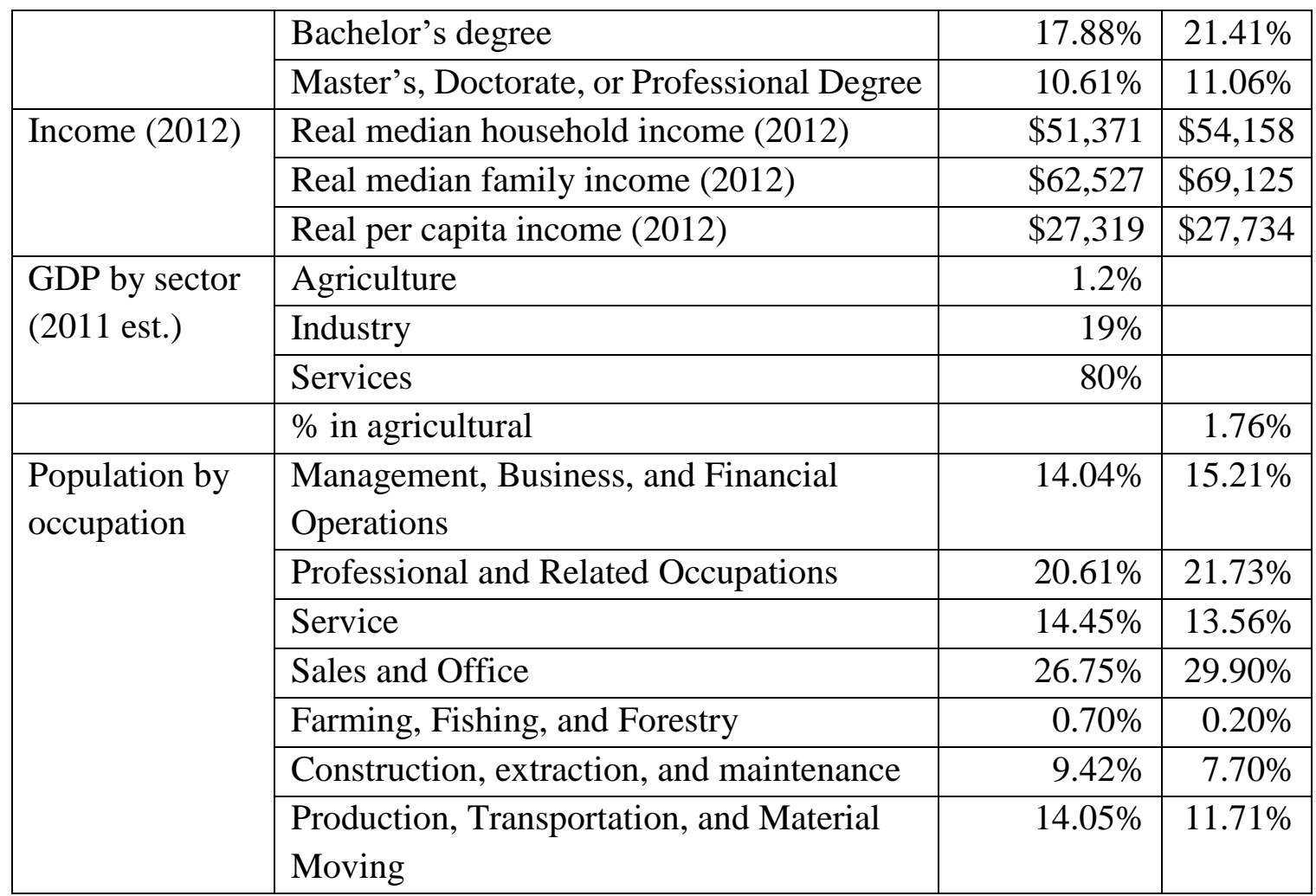

*Source: Race - as given by the 2010 census and United States Census Bureau,

Education and income - as given by the census ACS 1-year survey reports, Population by occupation - sperlings best places

\section{Department Selection}

The survey was distributed to various governmental departments within the two cities. I followed the approach used in previous studies (e.g., Newman, 1994) and based the selection of the departments on Lowi's classification of policy types ${ }^{8} \cdot \operatorname{Lowi}^{9}(1964)$ distinguishes between three policy types: regulatory policy, distributive policy, and redistributive policy. Government agencies are charged with the implementation of

\footnotetext{
${ }^{8}$ See Appendix 1 for further elaboration of the criteria used in the categorization of the individual municipal department.

${ }^{9}$ Lowi (1974) adds one more agency model to the original three: the constituent agency model. This fourth agency model is not immediately relevant to this study, as it focuses on boundary and jurisdictional issues rather than on functional or policy content (Lowi, 1972; Newman, 1994; Wright, 1988). As noted, the present study focuses on the first three models
} 
various policies. Agency types are related to the goals of specific policies, which are in turn reflected in the mission statements of government agencies. Lowi's policy typology has been used as a theoretical basis by many public administration scholars (e.g., Newman, 1994; Ripley \& Franklin, 1987).

Regulatory agencies in the city of Omaha include Permits and Inspections, Housing and Community Development, and Urban Planning; regulatory agencies in Wonju include Traffic Administration, Architecture, and Construction Accident Prevention. These regulatory agencies are responsible for administering and enforcing zoning and subdivision regulations, enforcing building codes and the minimum dwelling standards ordinance, carrying out ordinances for permits and inspection, and condemning and removing hazardous buildings.

Distributive agencies in the city of Omaha include Public Works; distributive agencies in Wonju include Health and Physical Education, Parks, Information and Communication, and Forests. The mission of these agencies is to effectively meet the environmental quality needs of the citizens. The departments provide many of the basic services that affect the daily lives of all who live and work in the designated city. These departments' key responsibilities are the design, construction, and maintenance of the city's infrastructure. These agencies are defined by Lowi and the definition is almost in direct opposition to regulatory agencies in terms of mission. Namely, both agency models are responsible for policies that work directly on or through individuals, but the relationship is one of patron and client rather than controller and controlled (Newman, 
1994). Consequently, "distributive agencies can operate in their political environment almost as though they had unlimited resources" (Lowi, 1985, p. 87).

Redistributive agencies in the city of Omaha include Human Resources and Human Rights and Relations; redistributive agencies in Wonju include Welfare Policy, Livelihood Security, and Women and Family. These departments are charged with civil rights enforcement, contract compliance, and community relations/discrimination prevention. They are responsible for the investigation, elimination, and prevention of all forms of prohibited discrimination, including that based on race, creed, color, religion, sex, national origin, age, disability, marital status, familial status, retaliation, sexual orientation, gender identity or any other form of discrimination proscribed by ordinance or resolution and one appointed council: the Economic Inclusion Council. The goal is ensuring equal opportunity and treatment for all citizens of the city. Their redistributive policy and programs are intended to manipulate the allocation of wealth, property, or rights among social classes or racial groups in society, often transferring some value to one group at the expense of another group (Ripley \& Franklin, 1987; Newman, 1994). Social welfare programs are commonly identified as redistributive in terms of intent and impact (Wright, 1988).

Therefore, I selected departments that match the three policy types as identified by Lowi. The agencies selected in the city of Omaha, Nebraska, in the United States include Public Works (distributive agency), Human Resources and Human Rights and Relations (redistributive agency), and Permits and Inspections, Housing and Community Development, and Urban Planning (regulatory agency). In the case of South Korea, the 
departments selected in Wonju city include Health and Physical Education, Parks, Information and Communication, and Forests (distributive agency), Welfare Policy, Livelihood Security, and Women and Family (redistributive agency), and Traffic Administration, Architecture, and Construction Accident Prevention (regulatory agency). A greater number of departments were selected within Wonju city to compensate for the larger number of staff employed in the departments of the city of Omaha. Table 13 presents department selection for the city of Omaha and Wonju city.

Table 13: Department Selection

\begin{tabular}{|c|c|c|}
\hline \multirow{2}{*}{$\begin{array}{l}\text { Type of } \\
\text { Agencies }\end{array}$} & \multicolumn{2}{|c|}{ Department } \\
\hline & Omaha & Wonju \\
\hline $\begin{array}{l}\text { Distributive } \\
\text { agency }\end{array}$ & Public Works (572) & $\begin{array}{l}\text { Health and Physical Education (17) } \\
\text { Parks (23) } \\
\text { Information and Communications (23) } \\
\text { Forests (19) }\end{array}$ \\
\hline $\begin{array}{l}\text { Redistributive } \\
\text { agency }\end{array}$ & $\begin{array}{l}\text { Human Rights and Relations (8) } \\
\text { Human Resources (21) }\end{array}$ & $\begin{array}{l}\text { Welfare Policy (21) } \\
\text { Livelihood Security (28) } \\
\text { Women and Family (18) }\end{array}$ \\
\hline $\begin{array}{l}\text { Regulatory } \\
\text { agency }\end{array}$ & $\begin{array}{l}\text { Planning (114) } \\
\text { Housing and Community } \\
\text { Development (29) } \\
\text { Permits and Inspections (11) } \\
\text { Urban Planning (19) }\end{array}$ & $\begin{array}{l}\text { Traffic Administration (40) } \\
\text { Architecture (17) } \\
\text { Construction Accident Prevention (23) }\end{array}$ \\
\hline
\end{tabular}

*Number in parenthesis indicates the number of staff.

\section{Data Collection Process}

A self-administered questionnaire was developed as an online and paper-based survey. After review and approval from Florida International University's Institutional Review Board (IRB), I contacted the Human Rights and Relations department of Wonju 
city and the city of Omaha and obtained permission to conduct this research on their organizations. In each case, participants were informed that their participation was voluntary and their responses were anonymous. No identifying information was included in the questionnaire.

The data reported in this dissertation were collected in both online and paperbased surveys ${ }^{10}$. For the city of Omaha, an online survey using the FIU Qualtrics system was utilized to save costs and time. After permission from the Human Rights and Relations department was obtained, permission from each department's director was required to distribute the online survey web link to staff. I received permission from all department directors. After respondents' consents were secured, the survey web link was distributed to staff by each department director. I conducted the survey for three months_-from November 2015 to January 2016.

For Wonju city, a paper-based survey was used to ensure adequate response rates. In fact, for security issues Wonju city, was not able to provide their employees' email addresses. Therefore, I distributed the paper-based survey to each department in October 2015. It took two weeks to receive all responses.

\footnotetext{
${ }^{10}$ This dissertation used a self-administered online survey method and a self-administered mail survey method. These survey methods have several advantages when compared to interview (Singleton and Straits, 2005): 1. Many individuals can be contacted at the same time. 2 . Each selected respondent receives identical questions. 3. A written questionnaire provides a vehicle for expression without fear of embarrassment to the respondent. 5. Respondents are free to select a convenient time to respond and to spend sufficient time to think about each answer. 6. Persons in remote or distant areas are reached. 7. Interviewer biases are avoided (Singleton and Straits, 2005).
} 
Table 14: Survey Distribution

\begin{tabular}{|c|c|c|c|c|c|}
\hline \multirow{2}{*}{$\begin{array}{l}\text { Type of } \\
\text { Agencies }\end{array}$} & \multicolumn{2}{|c|}{ The City of Omaha } & \multicolumn{2}{|c|}{ Wonju City } & \multirow[t]{2}{*}{ Total } \\
\hline & Departments & Distribution & Departments & Distribution & \\
\hline $\begin{array}{l}\text { Distributive } \\
\text { agency }\end{array}$ & Public Works & 70 & $\begin{array}{l}\text { Health and Physical } \\
\text { Education } \\
\text { Parks } \\
\text { Information and } \\
\text { Communications } \\
\text { Forests }\end{array}$ & $\begin{array}{l}17 \\
23 \\
23 \\
20\end{array}$ & 153 \\
\hline $\begin{array}{l}\text { Redistributive } \\
\text { agency }\end{array}$ & $\begin{array}{l}\text { Human Rights and } \\
\text { Relations } \\
\text { Human Resources }\end{array}$ & $\begin{array}{c}8 \\
21\end{array}$ & $\begin{array}{l}\text { Welfare Policy } \\
\text { Livelihood Security } \\
\text { Women and Family }\end{array}$ & $\begin{array}{l}21 \\
28 \\
18\end{array}$ & 96 \\
\hline $\begin{array}{l}\text { Regulatory } \\
\text { agency }\end{array}$ & $\begin{array}{l}\text { Housing \& Community } \\
\text { Development } \\
\text { Permits and Inspections } \\
\text { Urban Planning }\end{array}$ & $\begin{array}{l}29 \\
50 \\
19\end{array}$ & $\begin{array}{l}\text { Traffic Administration } \\
\text { Architecture } \\
\text { Construction Accident } \\
\text { Prevention }\end{array}$ & $\begin{array}{l}20 \\
17 \\
23\end{array}$ & 158 \\
\hline Total & 197 & & 210 & & 407 \\
\hline
\end{tabular}

As a whole, the survey was distributed to 407 respondents in the two cities. Table 14 shows that the online survey was sent to 197 public servants of the city of Omaha who have an email account with the city. For example, a significant portion of public works' staff are hourly crew members that do not have email addresses; this survey was not accessible to them. That is fairly common in large public works departments. For Wonju city, the paper-based survey was sent to all staff for each department-except the traffic administration department. The number of employees in the Traffic Administration department is 40 . Half of the staff, however, work outside of the office. Therefore, they did not participate in the survey.

\section{Survey Instrument Development}

The survey questionnaires and measurement scale were developed on the basis of the literature review and the objectives of the study. The survey items, grouped by 
variable, are presented in Table 15. Summated rating scale was used over single yes-no answers. A questionnaire with a 5-point, Likert-type response scale was used. It mostly included questions with ordinal level responses (e.g., 1. strongly disagree, 2. disagree, 3. neutral, 4. agree, and 5. strongly agree). A Likert-type response scale is commonly used to measure attitudes (Singleton \& Straits, 2005). Single yes-or-no questions are insufficient in terms of precision and reliability (Spector, 1992). Single items do not produce consistent responses by people over time. Also, they are imprecise because they restrict measurement to only two levels.

To assure reliability and validity for measures, questionnaires were adapted from the tested items reported in the literature, and new questions were developed where necessary. Also, to assure reliability and validity of the survey questionnaire, researchers must make an effort to make sure that: questions are clear, easily readable, and brief; vocabulary is appropriate for the respondent; and directions are clear and easy to follow (O’Sullivan, Russel, \& Berner, 2003; Singleton \& Straits, 2005).

Table 15: Survey Items per Variables

\begin{tabular}{|l|l|l|l|}
\hline Variable & Factor & Indicator & Source \\
\hline Culture & Power Distance & $\begin{array}{l}\text { Decision making, Opinion, Social interaction, } \\
\text { Agree decision, Delegating important task }\end{array}$ & $\begin{array}{l}\text { Hofstede } \\
\text { (2002) }\end{array}$ \\
\cline { 2 - 3 } & Uncertainty & $\begin{array}{l}\text { Having instructions, Follow instructions, Rules } \\
\text { and regulations, Standardized work procedures, } \\
\text { Instructions for operations }\end{array}$ & \begin{tabular}{l} 
(2011) \\
\cline { 2 - 3 }
\end{tabular} \\
\cline { 2 - 3 } & Collectivism & $\begin{array}{l}\text { Sacrifice self-interest, Stick with the group, } \\
\text { Group welfare, Group success } \\
\text { Individuals' goal, Group loyalty }\end{array}$ & \\
\cline { 2 - 3 } & Long-Term & $\begin{array}{l}\text { Thrift, Persistence, Personal steadiness and } \\
\text { stability, Long-term planning, Giving up today's } \\
\text { fun for success, Working hard for success in } \\
\text { future }\end{array}$ & \\
\cline { 2 - 3 } & Masculinity & $\begin{array}{l}\text { Professional career, Problem solving, Solving } \\
\text { difficult problems, Jobs }\end{array}$ & \\
\cline { 2 - 3 } & & & \\
\hline
\end{tabular}




\begin{tabular}{|c|c|c|c|}
\hline \multirow[t]{3}{*}{ Social Capital } & $\begin{array}{l}\text { Structural } \\
\text { social capital }\end{array}$ & $\begin{array}{l}\text { Internal co-ordination } \\
\text { External co-ordination } \\
\text { Internal connectivity } \\
\text { External connectivity } \\
\end{array}$ & \multirow{3}{*}{$\begin{array}{l}\text { Andrews } \\
(2010) \\
\text { Miller } \\
(1983) \\
\text { Cusack } \\
(1999) \\
\text { Tsai \& } \\
\text { Ghoshal } \\
\text { (1998) }\end{array}$} \\
\hline & $\begin{array}{l}\text { Relational } \\
\text { social capital }\end{array}$ & $\begin{array}{l}\text { Interpersonal trust: local government head, top- } \\
\text { management and staff, co-worker, local assembly } \\
\text { man, and citizen } \\
\text { Institutional trust: public servants labor union, } \\
\text { local council, community organization, and other } \\
\text { departments }\end{array}$ & \\
\hline & $\begin{array}{l}\text { Cognitive } \\
\text { social capital }\end{array}$ & $\begin{array}{l}\text { Understanding of mission, values, and objectives } \\
\text { Value of objectives } \\
\text { Conflict with objectives } \\
\text { Achievement of objectives }\end{array}$ & \\
\hline \multirow[t]{4}{*}{$\begin{array}{l}\text { Organizational } \\
\text { Performance }\end{array}$} & Efficiency & $\begin{array}{l}\text { Business process time reduction, business } \\
\text { process cost cutting, accuracy of business } \\
\text { process, administrative efficiency improvement }\end{array}$ & \multirow{4}{*}{$\begin{array}{l}\text { Adams } \\
(1963 ; \\
1965) \\
\text { Ostrom } \\
(1975)\end{array}$} \\
\hline & Effectiveness & $\begin{array}{l}\text { Goal attainment, qualitative satisfaction, } \\
\text { quantitative satisfaction }\end{array}$ & \\
\hline & Responsiveness & $\begin{array}{l}\text { Reflection of client (citizen)'s desire, customer } \\
\text { satisfaction, addressed client demands in a timely } \\
\text { manner }\end{array}$ & \\
\hline & Equity & $\begin{array}{l}\text { Distributive equity } \\
\text { Procedural equity } \\
\text { Interactional equity }\end{array}$ & \\
\hline
\end{tabular}

This study utilized e-mail or online and paper-based survey methods to obtain high response rates. The online survey—using Qualtrics technology—was sent to public officials in the city of Omaha, Nebraska, in the United States and a paper-based survey was sent to public officials in Wonju city in South Korea.

\section{Statistical Analysis Methods}

The main variables, social capital and organizational performance, were operationalized using survey data. Multiple-item measures were used to examine unobservable constructs to increase reliability. Each hypothesis was tested and the constructs were measured by multiple items or questions. To do so, factor analysis and reliability analysis was used to determine whether or not each question measures similar 
content. After identifying the scales obtained by factor analysis, a test for reliability or internal consistency was conducted. In order to assess internal consistency, the coefficient alpha developed by Cronbach (Hatcher, 1994) was used in this study.

Descriptive statistics analysis was conducted to examine the demographic characteristics of survey respondents and the minimum, maximum, mean, and standard deviation for all variables used in this study. Correlation analysis was conducted to examine the basic relationships among all the study variables and to check for possible multicollinearity problems among the variables.

To test the hypothesized effects of culture and social capital on agencies' performance, the study used various statistical techniques—including t-test, ANOVA analysis, factor analysis, linear regression, dummy regression, and moderated regression analysis. More specifically, data collected was analyzed as follows. I used descriptive statistics to examine the characteristic of samples, such as mean and frequency, then I did factor analysis to describe variability among observed, correlated variables and to search for joint variations. Linear regression analysis was used to test Hypotheses 1 regarding the relationship between social capital and organizational performance. Moderated regression analysis was conducted to examine Hypotheses 2 (if culture influences the relationship between social capital and organizational performance). Lastly, dummy regression analysis was used to examine Hypotheses 3 (if agency type has an influence on culture, social capital, and organizational performance in public sector organizations). 


\section{Summary}

This chapter discussed the analysis model and research design of the present investigation. For the major variables of this study, the measurement index and conceptual framework was developed based on previous theoretical discussions. In the methodology section, this chapter presented details of the sample and data collection. Countries were chosen based on Hofstede's national culture; cities were selected to be as close as possible to the national averages; departments were selected using Lowi's classification of policy types. Lastly, this chapter presented the survey instrument and statistical analysis methods. 


\section{CHAPTER 4: RESULTS AND FINDINGS}

The previous chapter discussed the research model, data sources, statistical methods, measurement of variables, and descriptive statistics of survey items. This chapter will present the results of the data collection and present findings from the hypotheses tests. The chapter is organized into three sections: the analysis and results of the Korean data, the analysis and results of the United States data, and a comparison of South Korea and the United States.

\section{South Korea}

\section{Sample Characteristics}

As mentioned in Chapter 3, public servants from Wonju city responded to a paper-based survey questionnaire. As shown in Table 16, the 210 surveys were distributed to the Health and Physical Education, Parks, Information and Communications, and Forests departments (distributive agencies); the Welfare Policy, Livelihood Security, and Women and Family departments (redistributive agencies); and the Traffic Administration and Architecture departments (regulatory agencies). Out of 210 distributed surveys, I received 183 usable and valid responses - an overall response rate of 87.1 percent. 
Table 16: Survey Distribution and Response (South Korea)

\begin{tabular}{|c|c|c|c|c|}
\hline \multirow{2}{*}{$\begin{array}{l}\text { Type of } \\
\text { Agencies }\end{array}$} & \multicolumn{4}{|c|}{ Wonju City } \\
\hline & Departments & Distribution & Responses & $\begin{array}{c}\text { Response } \\
\text { Rate }\end{array}$ \\
\hline $\begin{array}{l}\text { Distributive } \\
\text { agency }\end{array}$ & $\begin{array}{l}\text { Health and Physical Education } \\
\text { Parks } \\
\text { Information and Communications } \\
\text { Forests }\end{array}$ & $\begin{array}{l}17 \\
23 \\
23 \\
20\end{array}$ & $\begin{array}{l}13 \\
23 \\
19 \\
18\end{array}$ & $\begin{array}{l}76.5 \% \\
100 \% \\
82.6 \% \\
90.0 \%\end{array}$ \\
\hline $\begin{array}{l}\text { Redistributive } \\
\text { agency }\end{array}$ & $\begin{array}{l}\text { Welfare Policy } \\
\text { Livelihood Security } \\
\text { Women and Family }\end{array}$ & $\begin{array}{l}21 \\
28 \\
18\end{array}$ & $\begin{array}{l}18 \\
23 \\
11\end{array}$ & $\begin{array}{l}85.7 \% \\
82.1 \% \\
61.0 \%\end{array}$ \\
\hline $\begin{array}{l}\text { Regulatory } \\
\text { agency }\end{array}$ & $\begin{array}{l}\text { Traffic Administration } \\
\text { Architecture } \\
\text { Construction Accident Prevention }\end{array}$ & $\begin{array}{l}20 \\
17 \\
23\end{array}$ & $\begin{array}{l}19 \\
16 \\
23\end{array}$ & $\begin{array}{l}95.0 \% \\
94.1 \% \\
100 \%\end{array}$ \\
\hline & Total & 210 & 183 & $87.1 \%$ \\
\hline
\end{tabular}

Table 17 summarizes the demographic information of survey respondents. Of all respondents, the proportion of male respondents $(63.5 \%)$ is higher than that of female respondents $(36.5 \%)$. In terms of education, college graduates comprise the largest group with $68.5 \%$, followed by 2 -year associate degree graduates (13.8\%), people with high school education (9.4\%), people with a Master's degree (6.6\%), and people with a doctorate degree $(1.7 \%)$. For department, the response rate of the distributive agency $(39.9 \%)$ is the highest, followed by the regulatory agency (31.7\%), and the redistributive agency $(28.4 \%)$. 
Table 17: Descriptive Statistics of Survey Respondents (South Korea)

\begin{tabular}{|l|c|c|c|}
\hline \multicolumn{2}{|c|}{} & Frequency & Percent \\
\hline Gender & Male & 115 & 63.5 \\
& Female & 66 & 36.5 \\
& Total & 183 & 100 \\
\hline Education & High school graduate & 17 & 9.4 \\
& 2-year associate degree & 25 & 13.8 \\
& College graduate & 124 & 68.5 \\
& Master's degree & 12 & 6.6 \\
& Doctorate degree & 3 & 1.7 \\
& Total & 181 & 100 \\
\hline Department & Distributive agency & 73 & 39.9 \\
& Redistributive agency & 52 & 28.4 \\
& Regulatory agency & 58 & 31.7 \\
& Total & 183 & 100 \\
\hline
\end{tabular}

In terms of age, respondents' average age is about 42 years with a standard deviation of 9.31. The minimum and maximum for age is 24 and 64 years, respectively. Regarding working experience, the mean for full-time work experience is 15.6 years with a standard deviation of 9.32, and the mean for public sector work experience is 13.9 years with a standard deviation of 10.59 . The mean of years-working in the current position is 3.7 years with a standard deviation of 5.38. The reason why the mean of years-working in the current position is low is that public servants in South Korea work on a rotation. If they work in a department for a certain period (about 3 to 5 years), they will subsequently move to another department.

Table 17: Descriptive Statistics of Survey Respondents (South Korea) - continued

\begin{tabular}{|c|c|c|c|c|c|c|}
\hline \multicolumn{2}{|c|}{} & $\mathrm{N}$ & Minimum & Maximum & Mean & SD \\
\hline \multicolumn{2}{|c|}{ Age } & 178 & 24 & 64 & 41.9 & 9.31997 \\
\hline Years & Full-time & 177 & .00 & 42 & 15.6 & 10.40453 \\
Working & Public sector & 176 & .00 & 35 & 13.9 & 10.59637 \\
in & Current position & 178 & .00 & 30 & 3.7 & 5.38723 \\
& Valid N & 176 & & & & \\
\hline
\end{tabular}




\section{Factor Analysis and Reliability Analysis}

A number of multiple-items were developed and administered in this study. This study used a questionnaire with a 5-point Likert-type scale. These scale items represent variables that were developed to measure a smaller number of underlying constructs; factor analysis reduces the number of items to a small number of underlying groups (Spector, 1992) by analyzing the covariation among items. Groups of items that interrelate with one another more strongly than they relate to other groups of items will create factors. Therefore, this study used factor analysis to determine if each item measured the same idea.

Once the scales were created through the factor analysis, they must be tested for reliability or internal consistency. Reliability is an assessment of the degree of consistency between multiple measurements of a variable, indicating the homogeneity of items comprising a measurement scale. Cronbach's alpha coefficient is employed for assessment of internal consistency reliability. The values of the coefficient are usually positive, ranging from 0 to 1 , where larger values indicate higher levels of internal consistency. A widely used rule of thumb for Cronbach's alpha is 0.7 for a scale to demonstrate internal consistency, and Cronbach's alpha higher than 0.6 is acceptable (Hair et al., 2006).

Overall factor analysis with varimax rotation was conducted to test the unidimensionality of the items. Then, reliability analysis was conducted to assess the degree of consistency between multiple measurements. The results are represented in Table 18. The Cronbach's alpha for all variables is above 0.7 , which is considered 
acceptable. The value of Cronbach's alpha for organizational performance (.940) is the highest, followed by social capital (.936), and culture (.798).

Table 18: Factor Analysis and Reliability Analysis (South Korea)

\begin{tabular}{|c|c|c|c|c|c|}
\hline Variable & \multicolumn{2}{|l|}{ Factor } & \multirow{2}{*}{$\begin{array}{l}\begin{array}{l}\text { Factor } \\
\text { Loadings }\end{array} \\
.655 \\
\end{array}$} & \multicolumn{2}{|c|}{ Cronbach's Alpha } \\
\hline \multirow[t]{26}{*}{ Culture } & \multirow{5}{*}{ Power Distance } & PD1 & & \multirow{5}{*}{.771} & \multirow{26}{*}{.798} \\
\hline & & PD2 & .565 & & \\
\hline & & PD3 & .627 & & \\
\hline & & PD4 & .655 & & \\
\hline & & PD5 & .554 & & \\
\hline & \multirow[t]{5}{*}{ Uncertainty Avoidance } & UA1 & .392 & \multirow{5}{*}{.770} & \\
\hline & & UA2 & .645 & & \\
\hline & & UA3 & .639 & & \\
\hline & & UA4 & .630 & & \\
\hline & & UA5 & .715 & & \\
\hline & \multirow[t]{6}{*}{ Collectivism } & $\mathrm{CO} 1$ & .804 & \multirow{6}{*}{.833} & \\
\hline & & $\mathrm{CO} 2$ & .806 & & \\
\hline & & $\mathrm{CO} 3$ & .610 & & \\
\hline & & $\mathrm{CO} 4$ & .653 & & \\
\hline & & $\mathrm{CO} 5$ & .676 & & \\
\hline & & CO6 & .601 & & \\
\hline & \multirow[t]{6}{*}{ Long-Term Orientation } & LT1 & .530 & \multirow{6}{*}{.739} & \\
\hline & & LT2 & .456 & & \\
\hline & & LT3 & .640 & & \\
\hline & & LT4 & .555 & & \\
\hline & & LT5 & .656 & & \\
\hline & & LT6 & .647 & & \\
\hline & \multirow[t]{4}{*}{ Masculinity } & MA1 & .608 & \multirow{4}{*}{.827} & \\
\hline & & MA2 & .693 & & \\
\hline & & MA3 & .674 & & \\
\hline & & MA4 & .669 & & \\
\hline
\end{tabular}


Table 18: Factor Analysis and Reliability Analysis (South Korea) - continued

\begin{tabular}{|c|c|c|c|c|c|}
\hline Variable & \multicolumn{2}{|l|}{ Factor } & \multirow{2}{*}{$\begin{array}{l}\begin{array}{l}\text { Factor } \\
\text { Loadings }\end{array} \\
.765 \\
\end{array}$} & \multicolumn{2}{|c|}{$\begin{array}{l}\text { Cronbach's } \\
\text { Alpha }\end{array}$} \\
\hline \multirow[t]{17}{*}{ Social Capital } & \multirow[t]{4}{*}{ Structural social capital } & SSC1 & & \multirow{4}{*}{.833} & \\
\hline & & $\mathrm{SSC2}$ & .821 & & \\
\hline & & SSC3 & .761 & & \\
\hline & & $\overline{\mathrm{SSC} 4}$ & .713 & & \\
\hline & \multirow[t]{9}{*}{ Relational social capital } & $\mathrm{RSC1}$ & .713 & \multirow{9}{*}{.895} & \\
\hline & & $\overline{\mathrm{RSC} 2}$ & .815 & & \\
\hline & & $\mathrm{RSC3}$ & .738 & & \\
\hline & & $\mathrm{RSC} 4$ & .650 & & \\
\hline & & RSC5 & .800 & & \\
\hline & & RSC6 & .574 & & .936 \\
\hline & & $\mathrm{RSC7}$ & .697 & & \\
\hline & & RSC8 & .769 & & \\
\hline & & RSC9 & .813 & & \\
\hline & \multirow[t]{4}{*}{ Cognitive social capital } & $\mathrm{CSC} 1$ & .824 & \multirow{4}{*}{.856} & \\
\hline & & $\mathrm{CSC} 2$ & .844 & & \\
\hline & & $\mathrm{CSC} 3$ & .674 & & \\
\hline & & $\mathrm{CSC} 4$ & .699 & & \\
\hline
\end{tabular}

Table 18: Factor Analysis and Reliability Analysis (South Korea) - continued

\begin{tabular}{|c|c|c|c|c|c|}
\hline Variable & \multicolumn{2}{|l|}{ Factor } & $\begin{array}{l}\text { Factor } \\
\text { Loadings }\end{array}$ & \multicolumn{2}{|c|}{$\begin{array}{l}\text { Cronbach's } \\
\text { Alpha }\end{array}$} \\
\hline \multirow{13}{*}{$\begin{array}{l}\text { Organizational } \\
\text { Performance }\end{array}$} & \multirow{4}{*}{ Efficiency } & EFIC1 & .848 & \multirow[t]{4}{*}{.926} & \multirow{13}{*}{940} \\
\hline & & EFIC2 & .857 & & \\
\hline & & EFIC3 & .860 & & \\
\hline & & EFIC4 & .872 & & \\
\hline & \multirow[t]{3}{*}{ Effectiveness } & EFTV1 & .802 & \multirow[t]{3}{*}{.882} & \\
\hline & & EFTV2 & .812 & & \\
\hline & & EFTV3 & .838 & & \\
\hline & \multirow[t]{3}{*}{ Responsiveness } & RESP1 & .754 & \multirow[t]{3}{*}{.848} & \\
\hline & & RESP2 & .764 & & \\
\hline & & RESP3 & .791 & & \\
\hline & \multirow[t]{3}{*}{ Equity } & EQTY1 & .891 & \multirow[t]{3}{*}{.948} & \\
\hline & & EQTY2 & .916 & & \\
\hline & & EQTY3 & .853 & & \\
\hline
\end{tabular}

*Extraction Method: Maximum Likelihood

*12 factors extracted 
With factor analysis, it is necessary to check if the data matrix has sufficient correlations to justify the application of factor analysis. KMO and the Bartlett test of sphericity are methods to determine the appropriateness of factor analysis, examining for the presence of correlations among the items or variables. The index of KMO ranges from 0 to 1 and a value close to 1 means that each item is strongly compact and intercorrelated. Values higher than 0.5 are acceptable (Hair et al., 2006). As presented in Table 19, the value for KMO was .872, which is acceptable and Bartlett's test of sphericity is significant $(p \leq .001)$, which means that sufficient correlations exist among the items - allowing the study to proceed factor analysis.

Table 19: KMO and Bartlett's Test (South Korea)

\begin{tabular}{|l|l|r|}
\hline \multicolumn{2}{|l|}{ Kaiser-Meyer-Olkin Measure of Sampling Adequacy. } & .872 \\
\hline Bartlett's Test of Sphericity & Approx. Chi-Square & 7017.327 \\
& df & 1540 \\
& Sig. & .000 \\
\hline
\end{tabular}

As shown in Table 20, Goodness-of-Test is significant $(p \leq .001)$.

Table 20: Goodness-of-Test (South Korea)

\begin{tabular}{|c|c|c|}
\hline Chi-Square & df & Sig. \\
\hline 1346.738 & 934 & .000 \\
\hline
\end{tabular}

\section{Descriptive Statistics}

Table 21 summarizes the mean and standard deviation by factors. Among the culture factors, the mean for uncertainty avoidance is 4.11 with a standard deviation of 0.45. Higher levels of mean score are more likely to avoid uncertainty. For social capital 
factors, the mean for cognitive social capital (3.74) is the highest, followed by structural (3.53), and relational social capital (3.31). For organizational performance, the mean of most factors is over 3.60 ( 3.0 is neutral). The mean score for responsiveness is the most prevalent with 3.77, followed by effectiveness (3.71), efficiency (3.70), and equity (3.60). The mean for equity is relatively low compared to others.

Table 21: Mean and Standard Deviation by Factors (South Korea)

\begin{tabular}{|l|l|c|c|c|}
\hline \multicolumn{1}{|c|}{ Variable } & \multicolumn{1}{|c|}{ Factor } & $\mathrm{N}$ & Mean & Std. Deviation \\
\hline \multirow{5}{*}{ Culture } & Power Distance & 180 & 2.2267 & 0.65139 \\
\cline { 2 - 5 } & Uncertainty Avoidance & 182 & 4.1154 & 0.45248 \\
\cline { 2 - 5 } & Collectivism & 182 & 3.1465 & 0.60555 \\
\cline { 2 - 5 } & Long-Term Orientation & 181 & 3.9033 & 0.50186 \\
\cline { 2 - 5 } & Masculinity & 183 & 2.7131 & 0.78074 \\
\hline \multirow{5}{*}{ Social Capital } & Structural social capital & 183 & 3.5355 & 0.63395 \\
\cline { 2 - 5 } & Relational social capital & 178 & 3.3121 & 0.56183 \\
\cline { 2 - 5 } & Cognitive social capital & 180 & 3.7417 & 0.61289 \\
\hline & Efficiency & 183 & 3.709 & 0.62489 \\
\cline { 2 - 5 } & Effectiveness & 182 & 3.7179 & 0.6383 \\
\cline { 2 - 5 } & Responsiveness & 182 & 3.7711 & 0.5942 \\
\cline { 2 - 5 } & Equity & 180 & 3.6019 & 0.82864 \\
\hline
\end{tabular}

Mean and standard deviation by variable are presented in Table 22. First, the mean score for culture is 3.22 with a standard deviation of 0.34 . Second, the mean score for social capital is 3.53 with a standard deviation of 0.53 . Lastly, the mean score for organizational performance is 3.70 with a standard deviation of 0.56 .

Table 22: Mean and Standard Deviation by Variables (South Korea)

\begin{tabular}{|c|c|c|c|}
\hline Variable & $\mathrm{N}$ & Mean & Std. Deviation \\
\hline Culture & 183 & 3.2275 & 0.34012 \\
\hline Social Capital & 183 & 3.5343 & 0.53904 \\
\hline $\begin{array}{c}\text { Organizational } \\
\text { Performance }\end{array}$ & 183 & 3.7089 & 0.56273 \\
\hline
\end{tabular}




\section{Correlation Analysis}

Correlation analysis was conducted to examine the basic relationships among all study variables and to check for possible multicollinearity problems. The correlation matrix presented in Table 23 examined the relationship among the variables' indices of culture, social capital, and organizational performance. This study sought to understand if social capital would have an effect on organizational performance. The results presented in Table 23 indicate the presence of such effect. All Pearson's r coefficients range from .445 to .740 , indicating strong, positive, and significant relationships $(p \leq .001)$. The correlation between cognitive social capital and equity represents the strongest correlation (.740). The second strongest relationship is between structural social capital and equity with a coefficient of .694 . The third strongest relationship is between relational social capital and equity with a coefficient of .690. Equity has strong relationships with social capital variables. These results indicate that higher levels of social capital are related to higher levels of organizational performance. 
Table 23: Correlations of Culture and Social Capital and Organizational Performance (South Korea)

\begin{tabular}{|c|c|c|c|c|c|c|c|c|c|c|c|c|}
\hline & PD & UA & $\mathrm{CO}$ & LT & MA & SSC & RSC & CSC & EFIC & EFTV & RESP & $\begin{array}{l}\text { EQT } \\
\text { Y }\end{array}$ \\
\hline PD & 1 & & & & & & & & & & & \\
\hline$\overline{\mathrm{UA}}$ & -.132 & 1 & & & & & & & & & & \\
\hline $\mathrm{CO}$ & $\begin{array}{l}.009 \\
\end{array}$ & $\begin{array}{l}.220^{*} \\
*\end{array}$ & 1 & & & & & & & & & \\
\hline LT & -129 & $\begin{array}{l}.425^{*} \\
*\end{array}$ & $\begin{array}{l}.283 * \\
*\end{array}$ & 1 & & & & & & & & \\
\hline MA & $\begin{array}{l}.447 * \\
*\end{array}$ & .047 & $.165^{*}$ & .139 & 1 & & & & & & & \\
\hline SSC & .095 & $\begin{array}{l}.392 * \\
*\end{array}$ & $\begin{array}{l}.230^{*} \\
*\end{array}$ & $\begin{array}{l}.233^{*} \\
*\end{array}$ & $\begin{array}{l}.221 * \\
*\end{array}$ & 1 & & & & & & \\
\hline RSC & 年..046 & $\begin{array}{l}.314 * \\
*\end{array}$ & $\begin{array}{l}230^{*} \\
*\end{array}$ & $\begin{array}{l}305^{*} \\
*\end{array}$ & .033 & $\begin{array}{l}.716^{*} \\
*\end{array}$ & 1 & & & & & \\
\hline CSC & .048 & $\begin{array}{l}.438^{*} \\
*\end{array}$ & $\begin{array}{l}.253 * \\
*\end{array}$ & $\begin{array}{l}.417 * \\
*\end{array}$ & $.150^{*}$ & $\begin{array}{l}.706 * \\
*\end{array}$ & $\begin{array}{l}.663 * \\
*\end{array}$ & 1 & & & & \\
\hline EFIC & .024 & $\begin{array}{l}.429^{*} \\
*\end{array}$ & $\begin{array}{l}.251^{*} \\
*\end{array}$ & $\begin{array}{l}344^{*} \\
*\end{array}$ & $.193^{*}$ & $\begin{array}{l}.600 * \\
*\end{array}$ & $\begin{array}{l}.524 * \\
*\end{array}$ & $\begin{array}{l}.701 * \\
*\end{array}$ & 1 & & & \\
\hline $\begin{array}{l}\text { EFT } \\
\text { V }\end{array}$ & .054 & $\begin{array}{l}.377^{*} \\
*\end{array}$ & $\begin{array}{l}.247^{*} \\
*\end{array}$ & $\begin{array}{l}.339^{*} \\
*\end{array}$ & $.223^{*}$ & $\begin{array}{l}.582 * \\
*\end{array}$ & $\begin{array}{l}.561 * \\
*\end{array}$ & $\begin{array}{l}.693 * \\
*\end{array}$ & $\begin{array}{l}.751^{*} \\
*\end{array}$ & 1 & & \\
\hline RESP & -.045 & $\begin{array}{l}.300^{*} \\
*\end{array}$ & .117 & $\begin{array}{l}.327 * \\
*\end{array}$ & .102 & $\begin{array}{l}.445 * \\
*\end{array}$ & $\begin{array}{l}.498^{*} \\
*\end{array}$ & $\begin{array}{l}.520^{*} \\
*\end{array}$ & $\begin{array}{l}.583 * \\
*\end{array}$ & $\begin{array}{l}.557 * \\
*\end{array}$ & 1 & \\
\hline $\begin{array}{l}\text { EQT } \\
\text { Y }\end{array}$ & .145 & $\begin{array}{l}348^{*} \\
*\end{array}$ & $\begin{array}{l}.336^{*} \\
*\end{array}$ & $\begin{array}{l}.347^{*} \\
*\end{array}$ & $\begin{array}{l}.298^{*} \\
*\end{array}$ & $\begin{array}{l}.694^{*} \\
*\end{array}$ & $\begin{array}{l}.690^{*} \\
*\end{array}$ & $\begin{array}{l}.740^{*} \\
*\end{array}$ & $\begin{array}{l}.605^{*} \\
*\end{array}$ & $\begin{array}{l}.711 * \\
*\end{array}$ & $\begin{array}{l}.463 * \\
*\end{array}$ & 1 \\
\hline
\end{tabular}

**. Correlation is significant at the 0.01 level (2-tailed).

*. Correlation is significant at the 0.05 level (2-tailed).

Table 23: Correlations of Culture and Social Capital and Organizational Performance (South Korea) - continued

\begin{tabular}{|c|r|r|r|r|r|r|r|}
\hline & \multicolumn{1}{c|}{ PD } & \multicolumn{1}{c|}{ UA } & \multicolumn{1}{c|}{ CO } & \multicolumn{1}{c|}{ LT } & MA & \multicolumn{1}{c|}{ SC } & OP \\
\hline PD & 1 & & & & & & \\
\hline UA & -.132 & 1 & & & & & \\
\hline CO & -.009 & $.220^{* *}$ & 1 & & & & \\
\hline LT & -.129 & $.425^{* *}$ & $.283^{* *}$ & 1 & & & \\
\hline MA & $.447^{* *}$ & .047 & $.165^{*}$ & .139 & 1 & & \\
\hline SC & .052 & $.428^{* *}$ & $.276^{* *}$ & $.350^{* *}$ & $.157^{*}$ & 1 & \\
\hline OP & .066 & $.418^{* *}$ & $.290^{* *}$ & $.400^{* *}$ & $.264^{* *}$ & $.811^{* *}$ & 1 \\
\hline
\end{tabular}

**. Correlation is significant at the 0.01 level (2-tailed).

*. Correlation is significant at the 0.05 level (2-tailed). 
This study conducted a t-test to examine if there are differences between male and female participants in the mean for the all factors used in this study. The results are presented in Table 24. The mean differences for most factors is not statistically significant except power distance. The mean difference for power distance is significant at the level of $\mathrm{p}$-value $(p \leq .05)$. The higher power distance score of male respondents indicated that people are accepting of a hierarchical order in which everybody has a place and in which positions of authority need no further justification, and subordinates expect to be told what to do. However, the lower score on power distance means that female respondents value being independent and having equal rights.

Table 24: t-test of Gender and Factors (South Korea)

\begin{tabular}{|c|c|c|c|c|c|c|}
\hline Variable & \multicolumn{2}{|c|}{ Factor } & Mean & Std. & $\mathrm{t}$-value & $\mathrm{p}$-value \\
\hline \multirow[t]{10}{*}{ Culture } & \multirow[t]{2}{*}{ PD } & Male & 2.3158 & .71043 & \multirow[t]{2}{*}{2.515} & \multirow[t]{2}{*}{.011} \\
\hline & & Female & 2.0625 & .05631 & & \\
\hline & \multirow[t]{2}{*}{ UA } & Male & 4.1333 & .48603 & \multirow[t]{2}{*}{.561} & \multirow[t]{2}{*}{.114} \\
\hline & & Female & 4.0939 & .39258 & & \\
\hline & \multirow[t]{2}{*}{$\mathrm{CO}$} & Male & 3.2435 & .62333 & \multirow[t]{2}{*}{2.823} & \multirow[t]{2}{*}{.187} \\
\hline & & Female & 2.9821 & .54655 & & \\
\hline & \multirow[t]{2}{*}{$\mathrm{LT}$} & Male & 3.9536 & .51087 & \multirow[t]{2}{*}{1.651} & \multirow[t]{2}{*}{.667} \\
\hline & & Female & 3.8255 & .47274 & & \\
\hline & \multirow[t]{2}{*}{ MA } & Male & 2.9587 & .73890 & \multirow[t]{2}{*}{6.103} & \multirow[t]{2}{*}{.352} \\
\hline & & Female & 2.2841 & .67352 & & \\
\hline \multirow{2}{*}{\multicolumn{2}{|c|}{ Total }} & Male & 3.3230 & .34678 & \multirow[t]{2}{*}{5.341} & \multirow[t]{2}{*}{.013} \\
\hline & & Female & 3.0540 & .25316 & & \\
\hline \multirow[t]{6}{*}{ Social Capital } & \multirow[t]{2}{*}{ SSC } & Male & 3.6152 & .61352 & \multirow[t]{2}{*}{2.048} & \multirow[t]{2}{*}{.439} \\
\hline & & Female & 3.4167 & .65241 & & \\
\hline & \multirow[t]{2}{*}{ RSC } & Male & 3.3913 & .57680 & \multirow[t]{2}{*}{2.311} & \multirow[t]{2}{*}{.401} \\
\hline & & Female & 3.1905 & .50660 & & \\
\hline & \multirow[t]{2}{*}{$\mathrm{CSC}$} & Male & 3.7961 & .62095 & \multirow[t]{2}{*}{1.345} & \multirow[t]{2}{*}{.638} \\
\hline & & Female & 3.6680 & .58935 & & \\
\hline \multirow{2}{*}{\multicolumn{2}{|c|}{ Total }} & Male & 3.6012 & .54078 & \multirow[t]{2}{*}{1.972} & \multirow[t]{2}{*}{.700} \\
\hline & & Female & 3.4341 & .51629 & & \\
\hline \multirow{2}{*}{$\begin{array}{l}\text { Organizational } \\
\text { Performance }\end{array}$} & EFCY & Male & 3.7978 & .61674 & 2.333 & .888 \\
\hline & & Female & 3.5758 & .61546 & & \\
\hline
\end{tabular}




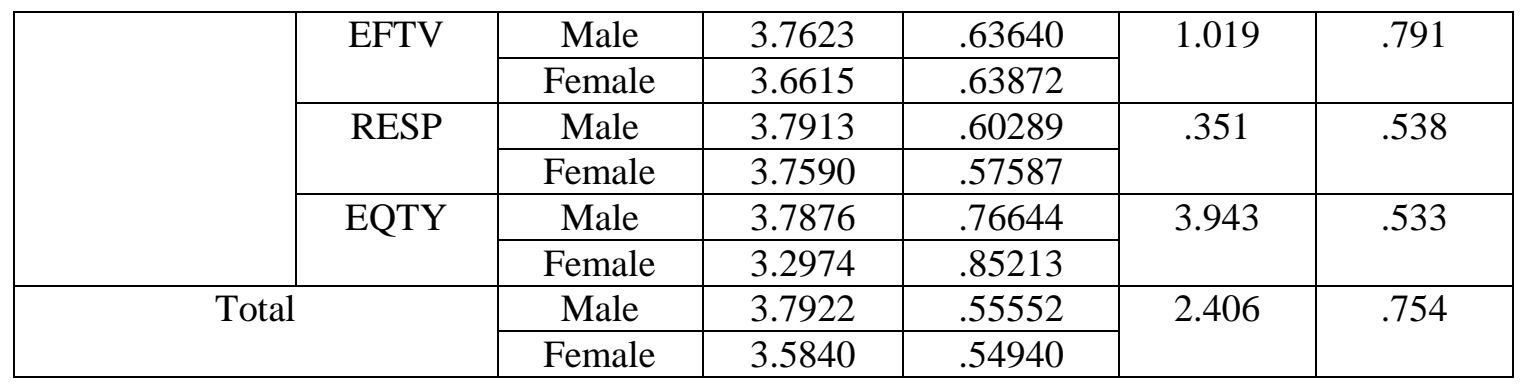

\section{Regression Analysis}

An ordinary least squares (OLS) multiple regression analysis was conducted to test hypotheses. OLS estimates for the efficiency, effectiveness, responsiveness, and equity indices are presented in Table 25. The results indicate that most models are statistically significant, with adjusted $\mathrm{R}^{2}$ scores ranging from .291 for the responsiveness index to .673 for the total dependent variables. Adjusted $\mathrm{R}^{2}$ scores for the remaining indexes are .487 for the effectiveness, .509 for the efficiency, and .627 for the equity index. Social capital in a public sector organization has a positive influence on organizational performance. Significantly, cognitive social capital has a statically positive and strong effect on all dependent variables. Specifically: first, an organization with higher levels of structural social capital is likely to have higher levels of organizational performance; second, an organization with higher levels of relational social capital is likely to have higher levels of organizational performance; and, lastly, an organization with higher levels of cognitive social capital is likely to have higher levels of organizational performance. These results provide support for Hypothesis 1. 
Table 25: Effect of Social Capital on Organizational Performance, Linear Regression (South Korea)

\begin{tabular}{|c|c|c|c|c|c|c|c|}
\hline & \multicolumn{6}{|c|}{ Independent Variables } \\
\hline & & \multicolumn{2}{|c|}{ Structural SC } & \multicolumn{2}{|c|}{ Relational SC } & \multicolumn{2}{|c|}{ Cognitive SC } \\
\hline & & $\beta$ & $\mathrm{p}$ & $\beta$ & $\mathrm{p}$ & $\beta$ & $\mathrm{p}$ \\
\hline \multirow{4}{*}{ 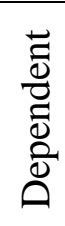 } & Efficiency & .204 & .019 & .016 & .842 & .541 & .000 \\
\hline & Effectiveness & .133 & .130 & .158 & .088 & .495 & .000 \\
\hline & Responsiveness & .055 & .591 & .275 & .005 & .280 & .004 \\
\hline & Equity & .191 & .012 & .268 & .000 & .427 & .000 \\
\hline & Total & .178 & .013 & .224 & .001 & .509 & .000 \\
\hline
\end{tabular}

*Adjusted $\mathrm{R}^{2}$ of Efficiency $=.509$, Adjusted $\mathrm{R}^{2}$ of Effectiveness $=.487$, Adjusted $\mathrm{R}^{2}$ of Responsiveness $=.291$, Adjusted $\mathrm{R}^{2}$ of Equity $=.627$, Adjusted $\mathrm{R}^{2}$ of Total Dependent Variables $=.673$

I conducted ANOVA analysis to test Hypotheses 3 and examine if culture, social capital, and organizational performance in a public sector organization would differ according to agency type. The results (displayed in Table 26) shows that all factors are statistically significant $(p \leq .05)$.

Table 26: ANOVA of Agency Type and Factors (South Korea)

\begin{tabular}{|c|c|c|c|c|c|}
\hline & $\begin{array}{c}\text { Sum of } \\
\text { Squares }\end{array}$ & df & Mean Square & F & Sig. \\
\hline PD & 6.764 & 2 & 3.382 & 8.652 & .000 \\
\hline UA & 1.348 & 2 & .674 & 3.378 & .036 \\
\hline CO & 5.094 & 2 & 2.547 & 7.440 & .001 \\
\hline LT & 1.573 & 2 & .787 & 3.199 & .043 \\
\hline MA & 10.221 & 2 & 5.111 & 9.133 & .000 \\
\hline Total & $\mathbf{1 . 5 4 3}$ & $\mathbf{2}$ & .771 & 7.133 & .001 \\
\hline SSC & 5.410 & 2 & 2.705 & 7.188 & .001 \\
\hline RSC & 4.008 & 2 & 2.004 & 6.761 & .001 \\
\hline CSC & 4.203 & 2 & 2.102 & 5.901 & .003 \\
\hline Total & $\mathbf{5 . 4 4 4}$ & $\mathbf{2}$ & $\mathbf{2 . 7 2 2}$ & $\mathbf{1 0 . 3 7 8}$ & .000 \\
\hline EFIC & 5.515 & 2 & 2.757 & 7.572 & .001 \\
\hline EFTV & 8.657 & 2 & 4.329 & 11.905 & .000 \\
\hline RESP & 2.266 & 2 & 1.133 & 3.290 & .040 \\
\hline EQTY & 5.272 & 2 & 2.636 & 3.966 & .021 \\
\hline Total & $\mathbf{4 . 4 1 3}$ & $\mathbf{2}$ & $\mathbf{2 . 2 0 7}$ & $\mathbf{7 . 4 7 5}$ & .001 \\
\hline
\end{tabular}


The mean differences for the culture, social capital, and organizational performance by agency type are significant. For example, distributive agency has higher levels of social capital and organizational performance compared to others. Mean of culture and social capital and organizational performance by agency type is presented in Table 27.

Table 27: Mean of Culture and Social Capital and Organizational Performance by Agency Type (South Korea)

\begin{tabular}{|l|l|c|c|c|c|}
\hline \multicolumn{2}{|l|}{} & $\mathrm{N}$ & Mean & $\begin{array}{c}\text { Std. } \\
\text { Deviation }\end{array}$ & Std. Error \\
\hline Culture & Distributive Agency & 73 & 3.3160 & .34589 & .04076 \\
& Redistributive Agency & 52 & 3.0881 & .27671 & .03913 \\
& Regulatory Agency & 58 & 3.2384 & .34883 & .04704 \\
& Total & 183 & 3.2275 & .34012 & .02556 \\
\hline Social Capital & Distributive Agency & 73 & 3.7473 & .47616 & .05732 \\
& Redistributive Agency & 52 & 3.4488 & .49039 & .06867 \\
& Regulatory Agency & 58 & 3.3465 & .57208 & .07714 \\
& Total & 183 & 3.5343 & .53904 & .04075 \\
\hline Organizational & Distributive Agency & 73 & 3.8975 & .48727 & .05703 \\
& Redistributive Agency & 52 & 3.5958 & .53687 & .07592 \\
& Regulatory Agency & 58 & 3.5640 & .61401 & .08205 \\
& Total & 183 & 3.7089 & .56273 & .04206 \\
\hline
\end{tabular}

Dummy regression analysis was conducted to examine if agency type has an influence on culture, social capital, and organizational performance in a public sector organization. The results (displayed in Table 28) show that all factors are statistically significant $(p \leq .001)$ except Dummy 2 (regulatory agency) in the culture model. For 
culture, distributive agency has an influence as $3.316-0.228(0)-0.078(0)=3.316$ and regulatory agency has an influence as $3.316-0.228(0)-0.078(1)=3.238$. For social capital, the coefficients of estimation regression equation are as follows:

Distributive agency: social capital $=3.747-0.299(0)-0.401(0)=3.747$

Redistributive agency: social capital $=3.747-0.299(1)-0.401(0)=3.448$

Regulatory agency: social capital $=3.747-0.299(0)-0.401(1)=3.346$

For organizational performance, the coefficients of estimation regression equation are as follows:

Distributive agency: social capital $=3.898-0.302(0)-0.334(0)=3.898$

Redistributive agency: social capital $=3.898-0.302(1)-0.334(0)=3.596$

Regulatory agency: social capital $=3.898-0.302(0)-0.334(1)=3.564$

These results indicate that the level of social capital and organizational performance in a public sector organization is likely to differ according to agency type.

Table 28: Dummy Regression of Agency Type and Culture and Social Capital and Performance (South Korea)

\begin{tabular}{|c|c|r|r|r|r|r|}
\hline \multicolumn{2}{|c|}{ Model } & \multicolumn{2}{c|}{$\begin{array}{c}\text { Unstandardized } \\
\text { Coefficients }\end{array}$} & $\begin{array}{c}\text { Standardized } \\
\text { Coefficients }\end{array}$ & \multirow{2}{*}{ Sig. } \\
\cline { 3 - 5 } \multicolumn{2}{c|}{} & \multicolumn{1}{c|}{ B } & $\begin{array}{c}\text { Std. } \\
\text { Error }\end{array}$ & Beta & \\
\hline Culture & Constant & 3.316 & .039 & & 85.562 & .000 \\
& Dummy1 & -.228 & .061 & -303 & -3.765 & .000 \\
& Dummy2 & -.078 & .059 & -106 & -1.319 & .189 \\
\hline Social Capital & Constant & 3.747 & .062 & & 60.778 & .000 \\
& Dummy1 & -.299 & .095 & -.252 & -3.156 & .002 \\
& Dummy2 & -.401 & .093 & -.346 & -4.330 & .000 \\
\hline Organizational & Constant & 3.898 & .064 & & 61.292 & .000 \\
performance & Dummy1 & -.302 & .100 & -.241 & -3.025 & .003 \\
& Dummy2 & -.334 & .097 & -.276 & -3.456 & .001 \\
\hline
\end{tabular}


Values of the regression analysis show the effect of the independent variable on dependent variable. However, other variables can also impact the process by which the independent variable influences the dependent variable. These other variables are called moderator variables, and regression analysis to confirm the moderating effect is called moderated regression analysis. Therefore, this study conducted moderated regression analysis to examine if culture impacts the process by which social capital influences organizational performance.

The results are presented in Table 29 and Table 30. The explanatory power of Model 3 has improved from Model 1. The value of $\mathrm{R}^{2}$ increases when the interacting variable is added in Model 3 to check for a moderating effect. It can be interpreted that the moderator variable — culture — has a positive effect on organizational performance. As a result, the effect of social capital on organizational performance is .659 and the effect when the 'culture' moderator variable is added in the model is .686. However, significant F change should be checked. The effect of social capital on organizational performance and the effect of culture on organizational performance is significant $(p \leq .001)$. However, there is no moderating effect on the process of the effect of social capital on organizational performance because the significant $\mathrm{F}$ change of culture, moderator variable is $\mathrm{p}=.110$. Thus, the results do not support Hypothesis 2 . 
Table 29: Effect of Social Capital on Organizational Performance, Moderator Regression - Model Summary ${ }^{\mathrm{d}}$ (South Korea)

\begin{tabular}{|c|c|c|c|c|c|c|c|c|c|c|}
\hline \multirow[t]{2}{*}{ Model } & \multirow[t]{2}{*}{$\mathrm{R}$} & \multirow[t]{2}{*}{$\mathrm{R}^{2}$} & \multirow[t]{2}{*}{ Adj. $R^{2}$} & \multirow[t]{2}{*}{ SE } & \multicolumn{5}{|c|}{ Change Statistics } & \multirow{2}{*}{$\begin{array}{l}\text { Durbin- } \\
\text { Watson }\end{array}$} \\
\hline & & & & & $\begin{array}{c}\text { R2 } \\
\text { Change }\end{array}$ & $\begin{array}{c}\mathrm{F} \\
\text { Change }\end{array}$ & df1 & $\mathrm{df} 2$ & $\begin{array}{l}\text { Sig. F } \\
\text { Change }\end{array}$ & \\
\hline 1 & $.812^{\mathrm{a}}$ & .659 & .657 & .32745 & .659 & 323.020 & 1 & 167 & .000 & \\
\hline 2 & $.825^{\mathrm{b}}$ & 681 & 678 & .31756 & .022 & 11.556 & 1 & 166 & .001 & \\
\hline 3 & $.828^{\mathrm{c}}$ & 686 & 681 & .31606 & .005 & 2.585 & 1 & 165 & .110 & 1.787 \\
\hline
\end{tabular}

a. Predictors: (Constant), Social Capital

b. Predictors: (Constant), Social Capital, Culture

c. Predictors: (Constant), Social Capital, Culture, Social Capital*Culture

d. Dependent Variable: Organizational Performance

Table 30: Effect of Social Capital on Organizational Performance, Moderator Regression - Coefficient ${ }^{\mathrm{a}}$ (South Korea)

\begin{tabular}{|c|c|c|c|c|c|c|}
\hline \multirow{2}{*}{\multicolumn{2}{|c|}{ Model }} & \multicolumn{2}{|c|}{$\begin{array}{l}\text { Unstandardized } \\
\text { coefficient }\end{array}$} & $\begin{array}{l}\text { Standardized } \\
\text { coefficient }\end{array}$ & \multirow[t]{2}{*}{$\mathrm{t}$} & \multirow[t]{2}{*}{$\mathrm{p}$} \\
\hline & & $\mathrm{B}$ & SE & Beta & & \\
\hline \multirow[t]{2}{*}{1} & (Constant) & .743 & .167 & & 4.442 & .000 \\
\hline & Social Capital & .838 & .047 & .812 & 17.973 & .000 \\
\hline \multirow[t]{3}{*}{2} & (Constant) & .128 & .243 & & .526 & .599 \\
\hline & Social Capital & .771 & .049 & .747 & 15.644 & .000 \\
\hline & Culture & .265 & .078 & .162 & 3.399 & .001 \\
\hline \multirow[t]{4}{*}{3} & (Constant) & -2.135 & 1.428 & & -1.495 & .137 \\
\hline & Social Capital & 1.397 & .392 & 1.353 & 3.564 & .000 \\
\hline & Culture & .970 & .446 & .595 & 2.177 & .031 \\
\hline & Culture*Social Capital & -.194 & .120 & -.876 & -1.608 & .110 \\
\hline
\end{tabular}

a. Dependent variable: Organizational Performance 


\section{The United States}

\section{Sample Characteristics}

For the United States data, the surveys were sent to public servants in Omaha city through the Qualtrics online survey program. As presented in Table 31, the 197 surveys were distributed to the departments of Public Works, Human Rights and Relations, Human Resources, and Planning. I received 120 responses — nine of which were inadequate, and thus excluded from the analysis. That left 111 usable and valid responses, a response rate of $56.3 \%$.

Table 31: Survey Distribution and Response (The United States)

\begin{tabular}{|l|l|c|c|c|}
\hline \multirow{2}{*}{$\begin{array}{l}\text { Type of } \\
\text { Agencies }\end{array}$} & Departments & Distribution & Response & $\begin{array}{c}\text { Response } \\
\text { Rate }\end{array}$ \\
\cline { 2 - 5 } $\begin{array}{l}\text { Distributive } \\
\text { agency }\end{array}$ & Public Works & 70 & 39 & $55.7 \%$ \\
\hline Redistributi & Human Rights and Relations & & & \\
\hline -ve agency & Human Resources & 8 & 8 & $100 \%$ \\
\hline Regulatory & Planning & 21 & 18 & $85.7 \%$ \\
agency & Housing \& Community Development & 29 & 7 & $24.1 \%$ \\
& Permits and Inspections & 50 & 30 & $60 \%$ \\
& Urban Planning & 19 & 9 & $47.3 \%$ \\
\hline \multicolumn{1}{|c|}{ Total } & 197 & 111 & $56.3 \%$ \\
\hline
\end{tabular}

The demographic information of survey respondents is summarized in Table 32.

Of all respondents, the proportion of male respondents (62.7\%) is higher than that of female respondents $(36.3 \%)$. Regarding education, college graduate is the highest with $47.3 \%$, followed by master's degree (22.7\%), 2-year associate degree (10.9\%), high school graduate and others (7.3\%), and doctorate degree (4.5\%). 
Table 32: Descriptive Statistics of Survey Respondents (The United States)

\begin{tabular}{|l|c|c|c|}
\hline \multicolumn{2}{|c|}{} & Frequency & Percent \\
\hline Gender & Male & 69 & 62.7 \\
& Female & 41 & 36.3 \\
& Total & 110 & 100 \\
\hline Education & High school graduate & 8 & 7.3 \\
& 2-year associate degree & 12 & 10.9 \\
& College graduate & 52 & 47.3 \\
& Master's degree & 25 & 22.7 \\
& Doctorate degree & 5 & 4.5 \\
& Others & 8 & 7.3 \\
& Total & 110 & 100 \\
\hline Department & Distributive agency & 39 & 35.1 \\
& Redistributive agency & 26 & 23.4 \\
& Regulatory agency & 46 & 41.4 \\
& Total & 111 & 100 \\
\hline
\end{tabular}

In terms of age, respondents' average age is 48 with a standard deviation of 10.87 . This result is 6 years greater than the mean of Wonju city. The minimum and maximum for age is 23 years old and 69 years, respectively. Regarding the working year, the mean for full-time work experience is 25.6 with a standard deviation of 10.91 and the mean for public sector work experience is 16.49 with a standard deviation of 10.16 . The mean of years-working in the current position is 11.02 with a standard deviation of 9.32 .

Table 32: Descriptive Statistics of Survey Respondents (The United States) - continued

\begin{tabular}{|c|c|c|c|c|c|c|}
\hline \multicolumn{2}{|c|}{} & $\mathrm{N}$ & Minimum & Maximum & Mean & SD \\
\hline \multicolumn{2}{|c|}{ Age } & 109 & 23 & 69 & 48.0 & 10.87939 \\
\hline Years & Full-time & 110 & 1.00 & 50 & 25.6 & 10.91357 \\
Working & Public sector & 110 & .10 & 50 & 16.49 & 10.16761 \\
in & Current position & 110 & .10 & 50 & 11.02 & 9.32788 \\
& Valid N & 109 & & & & \\
\hline
\end{tabular}

\section{Factor Analysis and Reliability Analysis}

Factor analysis was conducted to remove redundancy or duplication from the set of correlated variables and represent correlated variables with a smaller set of derived 
variables. After the scales were crated, reliability analysis was conducted to assess internal consistency reliability. Table 33 presents the results of factor analysis and reliability analysis.

Overall Cronbach's alpha is over 0.7, which is an acceptable value. The value of Cronbach's alpha for social capital (.937), is the highest, followed by organizational performance (.914), and culture (.671).

Table 33: Factor Analysis and Reliability Analysis (The United States)

\begin{tabular}{|c|c|c|c|c|c|}
\hline Variable & \multicolumn{2}{|l|}{ Factor } & \multirow{2}{*}{$\begin{array}{l}\begin{array}{l}\text { Factor } \\
\text { Loadings }\end{array} \\
.721 \\
\end{array}$} & \multicolumn{2}{|c|}{$\begin{array}{l}\text { Cronbach’s } \\
\text { Alpha }\end{array}$} \\
\hline \multirow[t]{26}{*}{ Culture } & \multirow[t]{5}{*}{ Power Distance } & PD1 & & \multirow{5}{*}{.724} & \multirow{26}{*}{.671} \\
\hline & & PD2 & .723 & & \\
\hline & & PD3 & .772 & & \\
\hline & & PD4 & .691 & & \\
\hline & & PD5 & .658 & & \\
\hline & \multirow[t]{5}{*}{ Uncertainty Avoidance } & UA1 & .717 & \multirow{5}{*}{.815} & \\
\hline & & UA2 & .814 & & \\
\hline & & UA3 & .814 & & \\
\hline & & UA4 & .752 & & \\
\hline & & UA5 & .785 & & \\
\hline & \multirow[t]{6}{*}{ Collectivism } & $\mathrm{CO} 1$ & .689 & \multirow{6}{*}{.773} & \\
\hline & & $\mathrm{CO} 2$ & .646 & & \\
\hline & & $\mathrm{CO} 3$ & .808 & & \\
\hline & & $\mathrm{CO} 4$ & .771 & & \\
\hline & & $\mathrm{CO} 5$ & .697 & & \\
\hline & & $\mathrm{CO} 6$ & .694 & & \\
\hline & \multirow[t]{6}{*}{ Long-Term Orientation } & LT1 & .716 & \multirow{6}{*}{.682} & \\
\hline & & LT2 & .685 & & \\
\hline & & LT3 & .710 & & \\
\hline & & LT4 & .661 & & \\
\hline & & LT5 & .591 & & \\
\hline & & LT6 & .686 & & \\
\hline & \multirow[t]{4}{*}{ Masculinity } & MA1 & .815 & \multirow{4}{*}{.850} & \\
\hline & & MA2 & .846 & & \\
\hline & & MA3 & .860 & & \\
\hline & & MA4 & .691 & & \\
\hline
\end{tabular}


Table 33: Factor Analysis and Reliability Analysis (The United States) - continued

\begin{tabular}{|c|c|c|c|c|c|}
\hline Variable & \multicolumn{2}{|l|}{ Factor } & $\begin{array}{l}\text { Factor } \\
\text { Loadings }\end{array}$ & \multicolumn{2}{|c|}{$\begin{array}{l}\text { Cronbach's } \\
\text { Alpha }\end{array}$} \\
\hline \multirow[t]{17}{*}{ Social Capital } & \multirow[t]{4}{*}{ Structural social capital } & SSC1 & .823 & \multirow{4}{*}{.782} & \multirow{17}{*}{.937} \\
\hline & & SSC2 & .884 & & \\
\hline & & SSC3 & .799 & & \\
\hline & & SSC4 & .766 & & \\
\hline & \multirow[t]{9}{*}{ Relational social capital } & RSC1 & .820 & \multirow{9}{*}{.902} & \\
\hline & & RSC2 & .805 & & \\
\hline & & RSC3 & .784 & & \\
\hline & & RSC4 & .743 & & \\
\hline & & RSC5 & .823 & & \\
\hline & & RSC6 & .765 & & \\
\hline & & RSC7 & .827 & & \\
\hline & & RSC8 & .843 & & \\
\hline & & RSC9 & .822 & & \\
\hline & \multirow[t]{4}{*}{ Cognitive social capital } & CSC1 & .802 & \multirow{4}{*}{.878} & \\
\hline & & $\mathrm{CSC} 2$ & .816 & & \\
\hline & & CSC3 & .823 & & \\
\hline & & CSC4 & .878 & & \\
\hline
\end{tabular}

Table 33: Factor Analysis and Reliability Analysis (The United States) - continued

\begin{tabular}{|c|c|c|c|c|c|}
\hline Variable & \multicolumn{2}{|l|}{ Factor } & $\begin{array}{l}\text { Factor } \\
\text { Loadings }\end{array}$ & \multicolumn{2}{|c|}{$\begin{array}{l}\text { Cronbach's } \\
\text { Alpha }\end{array}$} \\
\hline \multirow{13}{*}{$\begin{array}{l}\text { Organizational } \\
\text { Performance }\end{array}$} & \multirow[t]{4}{*}{ Efficiency } & EFIC1 & .620 & \multirow{4}{*}{.735} & \multirow{13}{*}{.914} \\
\hline & & EFIC2 & .734 & & \\
\hline & & EFIC3 & .900 & & \\
\hline & & EFIC4 & .854 & & \\
\hline & \multirow[t]{3}{*}{ Effectiveness } & EFTV1 & .794 & \multirow{3}{*}{.860} & \\
\hline & & EFTV2 & .861 & & \\
\hline & & EFTV3 & .895 & & \\
\hline & \multirow[t]{3}{*}{ Responsiveness } & RESP1 & .797 & \multirow{3}{*}{.858} & \\
\hline & & RESP2 & .756 & & \\
\hline & & RESP3 & .809 & & \\
\hline & \multirow[t]{3}{*}{ Equity } & EQTY1 & .901 & \multirow{3}{*}{.920} & \\
\hline & & EQTY2 & .898 & & \\
\hline & & EQTY3 & .873 & & \\
\hline
\end{tabular}

*Extraction Method: Maximum Likelihood

*12 factors extracted 
KMO and the Bartlett test of sphericity was conducted to determine the appropriatensess of factor analysis. The results are presented in Table 34 . The value for KMO is .776 which is acceptable and Bartlett's test of sphericity is significant $(p \leq .001)$ which means that sufficient correlations exist among the items, allowing the study to proceed factor analysis.

Table 34: KMO and Bartlett's Test (The United States)

\begin{tabular}{|l|l|r|}
\hline \multicolumn{2}{|l|}{ Kaiser-Meyer-Olkin Measure of Sampling Adequacy. } & .776 \\
\hline Bartlett's Test of Sphericity & Approx. Chi-Square & 4211.242 \\
& df & 1540 \\
& Sig. & .000 \\
\hline
\end{tabular}

As displayed in Table 35, Goodness-of-Test is significant $(p \leq .001)$.

Table 35: Goodness-of-Test (The United States)

\begin{tabular}{|c|c|c|}
\hline Chi-Square & df & Sig. \\
\hline 919.120 & 847 & .000 \\
\hline
\end{tabular}

\section{Descriptive Statistics}

The mean and standard deviation by factors are presented in Table 36. In terms of the culture factors, the mean scores for power distance, uncertainty avoidance, collectivism, long-term orientation, and masculinity are 2.03, 3.88, 3.19, 3.62, and 2.13, respectively (3.0 is neutral). The results show that respondents in the United States have a lower power distance, a lower uncertainty avoidance, a higher individualism, a short term orientation, and a lower masculinity compared to South Korea. 
For social capital factors, the mean for cognitive social capital (3.60) is the highest, followed by structural social capital (3.55) and relational social capital (3.33). These results are the same as in South Korea - in terms of the mean rank of social capital. Regarding organizational performance, the mean of responsiveness (3.66) is the highest, followed by effectiveness (3.50), equity (3.35), and efficiency (3.28). The mean for efficiency is relatively low compared to others.

Table 36: Mean and Standard Deviation by Factors (The United States)

\begin{tabular}{|l|l|l|l|c|}
\hline \multicolumn{1}{|c|}{ Variable } & \multicolumn{1}{|c|}{ Factor } & $\mathrm{N}$ & Mean & $\begin{array}{c}\text { Std. } \\
\text { Deviation }\end{array}$ \\
\hline \multirow{5}{*}{ Culture } & Power Distance & 111 & 2.0378 & .56730 \\
\cline { 2 - 5 } & Uncertainty Avoidance & 111 & 3.8865 & .55571 \\
\cline { 2 - 5 } & Collectivism & 111 & 3.1970 & .56460 \\
\cline { 2 - 5 } & Long-Term Orientation & 111 & 3.6219 & .45250 \\
\cline { 2 - 5 } & Masculinity & 111 & 2.1351 & .79614 \\
\hline \multirow{5}{*}{ Social Capital } & Structural social capital & 110 & 3.5568 & .65109 \\
\cline { 2 - 5 } & Relational social capital & 110 & 3.3393 & .62351 \\
\cline { 2 - 5 } & Cognitive social capital & 110 & 3.6000 & .71853 \\
\hline \multirow{4}{*}{\begin{tabular}{l} 
Prganizational \\
\cline { 2 - 5 }
\end{tabular}} & Efficiency & 110 & 3.2818 & .57480 \\
\cline { 2 - 5 } & Effectiveness & 110 & 3.5000 & .67086 \\
\cline { 2 - 5 } & Responsiveness & 110 & 3.6667 & .66667 \\
\cline { 2 - 5 } & Equity & 110 & 3.3576 & .85398 \\
\hline
\end{tabular}

Table 37 presents mean and standard deviation by variables. First, the mean score for culture is 2.97 with a standard deviation of 0.27 . Second, the mean score for social capital is 3.49 with a standard deviation of 0.59 . Third, the mean for organizational performance is 3.45 with a standard deviation of 0.57 . 
Table 37: Mean and Standard Deviation by Variables (The United States)

\begin{tabular}{|c|c|c|c|}
\hline Variable & $\mathrm{N}$ & Mean & Std. Deviation \\
\hline Culture & 111 & 2.9757 & .27275 \\
\hline Social Capital & 110 & 3.4987 & .59375 \\
\hline $\begin{array}{c}\text { Organizational } \\
\text { Performance }\end{array}$ & 110 & 3.4515 & .57016 \\
\hline
\end{tabular}

\section{Correlation Analysis}

Correlation analysis was conducted to investigate whether there is a relationship between variables, and to determine the direction of the relationship — whether it is positive, or negative, and to find the strength of the relationship between the two variables. The correlation matrix displayed in Table 38. The results show that social capital affects organizational performance. All Pearson's coefficients range from .513 to .678 , indicating strong, positive, and significant relationships at the 0.01 level. The correlation between relational social capital and equity represents the strongest correlation (.678). The second strongest relationship is between cognitive social capital and effectiveness with a coefficient of .647. The third strongest relationship is between cognitive social capital and responsiveness with a coefficient of .645. Equity and effectiveness have strong positive relationships with social capital variables. These results indicate that higher levels of social capital are likely to achieve higher levels of organizational performance. 
Table 38: Correlations of Culture and Social Capital and Organizational Performance (The United States)

\begin{tabular}{|c|c|c|c|c|c|c|c|c|c|c|c|c|}
\hline & PD & UA & $\mathrm{CO}$ & LT & MA & SSC & RSC & CSC & EFIC & EFTV & RESP & $\begin{array}{l}\text { EQT } \\
\text { Y }\end{array}$ \\
\hline PD & 1 & & & & & & & & & & & \\
\hline$\overline{\mathrm{UA}}$ & $\begin{array}{l}-.375 \\
* *\end{array}$ & 1 & & & & & & & & & & \\
\hline $\mathrm{CO}$ & -.174 & $\begin{array}{l}.304 * \\
*\end{array}$ & 1 & & & & & & & & & \\
\hline LT & $\begin{array}{l}-.334 \\
*\end{array}$ & $\begin{array}{l}.503 * \\
*\end{array}$ & $\begin{array}{l}.372 * \\
*\end{array}$ & 1 & & & & & & & & \\
\hline MA & $\begin{array}{l}.421 * \\
*\end{array}$ & $\begin{array}{l}-.259 \\
* *\end{array}$ & -.023 & $\begin{array}{l}-.242 \\
*\end{array}$ & 1 & & & & & & & \\
\hline SSC & -.044 & .086 & .174 & $\begin{array}{l}.305^{*} \\
*\end{array}$ & $\begin{array}{l}-.05 \\
3\end{array}$ & 1 & & & & & & \\
\hline RSC & .008 & .086 & .161 & $\begin{array}{l}.381 * \\
*\end{array}$ & $\begin{array}{l}-01 \\
5\end{array}$ & $\begin{array}{l}.723 \\
* *\end{array}$ & 1 & & & & & \\
\hline CSC & -.031 & .160 & $.210^{*}$ & $\begin{array}{l}.275^{*} \\
*\end{array}$ & $\begin{array}{l}-.04 \\
5\end{array}$ & $\begin{array}{l}.670 \\
* *\end{array}$ & $\begin{array}{l}.702 * \\
*\end{array}$ & 1 & & & & \\
\hline EFIC & -.118 & $.179 *$ & $.242 *$ & $\begin{array}{l}.431^{*} \\
*\end{array}$ & $\begin{array}{l}-.13 \\
4\end{array}$ & $\begin{array}{l}.611 \\
* *\end{array}$ & $\begin{array}{l}.513 * \\
*\end{array}$ & $\begin{array}{l}.550^{*} \\
*\end{array}$ & 1 & & & \\
\hline $\begin{array}{l}\text { EFT } \\
\text { V }\end{array}$ & -.088 & $\begin{array}{l}.225^{*} \\
*\end{array}$ & $.203^{*}$ & $\begin{array}{l}.433^{*} \\
*\end{array}$ & $\begin{array}{l}-.01 \\
2\end{array}$ & $\begin{array}{l}.568 \\
* *\end{array}$ & $\begin{array}{l}.630^{*} \\
*\end{array}$ & $\begin{array}{l}.647 * \\
*\end{array}$ & $\begin{array}{l}.761 * \\
*\end{array}$ & 1 & & \\
\hline RESP & -.082 & .166 & $.211 *$ & $\begin{array}{l}.315^{*} \\
*\end{array}$ & .017 & $\begin{array}{l}.572 \\
* *\end{array}$ & $\begin{array}{l}.593 * \\
*\end{array}$ & $\begin{array}{l}.645^{*} \\
*\end{array}$ & $\begin{array}{l}.395^{*} \\
*\end{array}$ & $\begin{array}{l}.524 * \\
*\end{array}$ & 1 & \\
\hline $\begin{array}{l}\text { EQT } \\
\text { Y }\end{array}$ & .061 & .157 & .149 & $\begin{array}{l}.321 * \\
*\end{array}$ & $\begin{array}{l}-.05 \\
4\end{array}$ & $\begin{array}{l}.611 \\
* *\end{array}$ & $\begin{array}{l}.678^{*} \\
*\end{array}$ & $\begin{array}{l}.567 * \\
*\end{array}$ & $\begin{array}{l}.590 * \\
*\end{array}$ & $\begin{array}{l}.585^{*} \\
*\end{array}$ & $\begin{array}{l}.560 * \\
*\end{array}$ & 1 \\
\hline
\end{tabular}

**. Correlation is significant at the 0.01 level (2-tailed).

*. Correlation is significant at the 0.05 level (2-tailed).

Table 38: Correlations of Culture and Social Capital and Organizational Performance (The United States) - continued

\begin{tabular}{|c|r|r|r|r|r|r|r|}
\hline & \multicolumn{1}{c|}{ PD } & \multicolumn{1}{c|}{ UA } & \multicolumn{1}{c|}{ CO } & \multicolumn{1}{c|}{ LT } & MA & \multicolumn{1}{c|}{ SC } & OP \\
\hline PD & 1 & & & & & & \\
\hline UA & $-.375^{* *}$ & 1 & & & & & \\
\hline CO & -.174 & $.304^{* *}$ & 1 & & & & \\
\hline LT & $-.334^{* *}$ & $.503^{* *}$ & $.372^{* *}$ & 1 & & & \\
\hline MA & $.421^{* *}$ & $-.259^{* *}$ & -.023 & $-.242^{*}$ & 1 & & \\
\hline SC & -.026 & .126 & $.205^{*}$ & $.356^{* *}$ & -.043 & 1 & \\
\hline OP & -.057 & $.223^{*}$ & $.238^{*}$ & $.448^{* *}$ & -.053 & $.816^{* *}$ & 1 \\
\hline
\end{tabular}

**. Correlation is significant at the 0.01 level (2-tailed).

*. Correlation is significant at the 0.05 level (2-tailed). 
T-test of gender and factors was conducted to assess whether the means of two groups, gender are statistically different from each other. As presented in Table 39, the mean differences for most factors are not statistically significant, except masculinity/femininity in the culture variable. The mean difference for masculinity/femininity is only significant at the level of $p$-value $(p \leq .05)$. In other words, male respondents are more likely to be masculine and career success oriented compared to female respondents.

Table 39: t-test of Gender and Factors (The United States)

\begin{tabular}{|c|c|c|c|c|c|c|}
\hline \multirow{2}{*}{$\begin{array}{c}\text { Variable } \\
\text { Culture }\end{array}$} & \multicolumn{2}{|c|}{ Factor } & \multirow{2}{*}{$\begin{array}{l}\text { Mean } \\
2.1159\end{array}$} & \multirow{2}{*}{$\begin{array}{c}\begin{array}{c}\text { Std. } \\
\text { Deviation }\end{array} \\
.63283\end{array}$} & \multirow{2}{*}{$\begin{array}{c}\text {-value } \\
1.924\end{array}$} & \multirow{2}{*}{$\begin{array}{c}\mathrm{p} \text {-value } \\
.199\end{array}$} \\
\hline & \multirow[t]{2}{*}{ PD } & Male & & & & \\
\hline & & Female & 1.9024 & .41743 & & \\
\hline & \multirow[t]{2}{*}{ UA } & Male & 3.8348 & .60387 & \multirow[t]{2}{*}{-1.283} & \multirow[t]{2}{*}{.544} \\
\hline & & Female & 3.9756 & .46518 & & \\
\hline & \multirow[t]{2}{*}{$\mathrm{CO}$} & Male & 3.2396 & .58046 & \multirow[t]{2}{*}{1.016} & \multirow[t]{2}{*}{.915} \\
\hline & & Female & 3.1260 & .54363 & & \\
\hline & \multirow[t]{2}{*}{ LT } & Male & 3.5899 & .50008 & \multirow[t]{2}{*}{-.816} & \multirow[t]{2}{*}{.404 } \\
\hline & & Female & 3.6626 & .35646 & & \\
\hline & \multirow[t]{2}{*}{ MA } & Male & 2.3732 & .83427 & \multirow[t]{2}{*}{4.397} & \multirow[t]{2}{*}{.023} \\
\hline & & Female & 1.7317 & .54311 & & \\
\hline \multirow[t]{2}{*}{ Tota } & & Male & 3.0307 & .29232 & \multirow[t]{2}{*}{2.891} & \multirow[t]{2}{*}{.027} \\
\hline & & Female & 2.8797 & .21012 & & \\
\hline \multirow[t]{6}{*}{ Social Capital } & \multirow[t]{2}{*}{ SSC } & Male & 3.5109 & .67306 & \multirow[t]{2}{*}{-.960} & \multirow[t]{2}{*}{.460} \\
\hline & & Female & 3.6341 & .61262 & & \\
\hline & \multirow[t]{2}{*}{ RSC } & Male & 3.3333 & .60017 & \multirow[t]{2}{*}{-.129} & \multirow[t]{2}{*}{.594} \\
\hline & & Female & 3.3493 & .66850 & & \\
\hline & \multirow[t]{2}{*}{ CSC } & Male & 3.5290 & .71812 & \multirow[t]{2}{*}{-1.350} & \multirow[t]{2}{*}{.798} \\
\hline & & Female & 3.7195 & .71194 & & \\
\hline \multirow{2}{*}{\multicolumn{2}{|c|}{ Total }} & Male & 3.4577 & .59885 & \multirow[t]{2}{*}{-.938} & \multirow[t]{2}{*}{.550} \\
\hline & & Female & 3.5676 & .58588 & & \\
\hline
\end{tabular}




\begin{tabular}{|c|c|c|c|c|c|c|}
\hline \multirow{8}{*}{$\begin{array}{l}\text { Organizational } \\
\text { Performance }\end{array}$} & \multirow[t]{2}{*}{ EFCY } & Male & 3.2536 & .58393 & \multirow[t]{2}{*}{-.666} & \multirow[t]{2}{*}{.797} \\
\hline & & Female & 3.3293 & .56302 & & \\
\hline & \multirow[t]{2}{*}{ EFTV } & Male & 3.4589 & .68624 & \multirow[t]{2}{*}{-.832} & \multirow[t]{2}{*}{.996} \\
\hline & & Female & 3.5691 & .64655 & & \\
\hline & \multirow[t]{2}{*}{ RESP } & Male & 3.7391 & .61002 & \multirow[t]{2}{*}{1.487} & \multirow[t]{2}{*}{.128} \\
\hline & & Female & 3.5447 & .74445 & & \\
\hline & \multirow[t]{2}{*}{ EQTY } & Male & 3.3816 & .79680 & \multirow[t]{2}{*}{.382} & \multirow[t]{2}{*}{.130} \\
\hline & & Female & 3.3171 & .95146 & & \\
\hline \multirow{2}{*}{\multicolumn{2}{|c|}{ Total }} & Male & 3.4583 & .55017 & \multirow[t]{2}{*}{.162} & \multirow[t]{2}{*}{.405} \\
\hline & & Female & 3.4400 & .60916 & & \\
\hline
\end{tabular}

\section{Regression Analysis}

Ordinary least squares (OLS) multiple regression analysis was conducted to test whether social capital has an effect on organizational performance. As presented in Table 40 , the results indicate that most models are statistically significant, with adjusted $\mathrm{R}^{2}$ scores ranging from .393 for efficiency index to .657 for total dependent variables. Adjusted $\mathrm{R}^{2}$ scores for the remaining indexes are .451 for responsiveness, .470 for effectiveness, and .481 for equity. These results suggest that social capital in a public sector organization has a positive influence on organizational performance. The effect of relational social capital on organizational performance is the most prevalent.

Significantly, relational social capital has the most prevalent influence on equity. These results support Hypothesis 1. 
Table 40: Effect of Social Capital on Organizational Performance, Linear Regression (The United States)

\begin{tabular}{|c|c|c|c|c|c|c|c|}
\hline & \multicolumn{6}{|c|}{ Independent Variables } \\
\hline & & \multicolumn{2}{|c|}{ Structural SC } & \multicolumn{2}{|c|}{ Relational SC } & \multicolumn{2}{|c|}{ Cognitive SC } \\
\hline & & $\beta$ & $\mathrm{p}$ & $\beta$ & $\mathrm{p}$ & $\beta$ & $\mathrm{p}$ \\
\hline \multirow{4}{*}{ 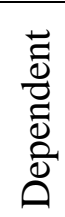 } & Efficiency & .372 & .000 & .037 & .737 & .192 & .033 \\
\hline & Effectiveness & .113 & .309 & .314 & .010 & .344 & .001 \\
\hline & Responsiveness & .169 & .113 & .209 & .089 & .369 & .000 \\
\hline & Equity & .282 & .045 & .610 & .000 & .131 & .287 \\
\hline & Total & .234 & .002 & .292 & .001 & .259 & .000 \\
\hline
\end{tabular}

*Adjusted $\mathrm{R}^{2}$ of Efficiency $=.393$, Adjusted $\mathrm{R}^{2}$ of Effectiveness $=.470$, Adjusted $\mathrm{R}^{2}$ of Responsiveness $=.451$, Adjusted $\mathrm{R}^{2}$ of Equity $=.481$, Adjusted $\mathrm{R}^{2}$ of Total Dependent Variables $=.657$

ANOVA analysis was conducted to test Hypothesis 3 and examine whether culture, social capital, and organizational performance in a public sector organization would vary by agency type. The results (presented in Table 41) show that most factors are not statistically significant, except cognitive social capital and equity. Cognitive social capital and equity are significant $(p \leq .05)$. This result differs markedly from the result of the Korean case-where all factors are statistically significant $(p \leq .05)$.

Table 41: ANOVA of Agency Type and Factors (The United States)

\begin{tabular}{|c|c|c|c|c|c|}
\hline & $\begin{array}{c}\text { Sum of } \\
\text { Squares }\end{array}$ & df & $\begin{array}{c}\text { Mean } \\
\text { Square }\end{array}$ & F & Sig. \\
\hline PD & 1.079 & 2 & .539 & 1.697 & .188 \\
\hline UA & .007 & 2 & .004 & .011 & .989 \\
\hline CO & 1.044 & 2 & .522 & 1.657 & .196 \\
\hline LT & .379 & 2 & .189 & .924 & .400 \\
\hline MA & 1.672 & 2 & .836 & 1.327 & .270 \\
\hline Total &. $\mathbf{3 8 4}$ & $\mathbf{2}$ &. $\mathbf{1 9 2}$ & $\mathbf{2 . 6 5 5}$ &. $\mathbf{0 7 5}$ \\
\hline SSC & .647 & 2 & .323 & .760 & .470 \\
\hline RSC & 1.225 & 2 & .612 & 1.592 & .208 \\
\hline CSC & 3.29 & 2 & 1.965 & 4.016 & .021 \\
\hline
\end{tabular}




\begin{tabular}{|c|c|c|c|c|c|}
\hline Total & $\mathbf{1 . 5 4 5}$ & $\mathbf{2}$ & $\mathbf{. 7 7 3}$ & $\mathbf{2 . 2 4 2}$ & $\mathbf{. 1 1 1}$ \\
\hline EFIC & .328 & 2 & .164 & .492 & .613 \\
\hline EFTV & .844 & 2 & .422 & .937 & .395 \\
\hline RESP & 1.597 & 2 & .798 & 1.823 & .166 \\
\hline EQTY & 5.793 & 2 & 2.896 & 4.205 & .017 \\
\hline Total & $\mathbf{1 . 3 0 1}$ & $\mathbf{2}$ & $\mathbf{. 6 5 0}$ & $\mathbf{2 . 0 3 9}$ & $\mathbf{. 1 3 5}$ \\
\hline
\end{tabular}

The mean differences for culture, social capital, and organizational performance by agency type are presented in Table 42. It can be interpreted that the mean differences are not significant, except culture, cognitive social capital, and equity.

Table 42: Mean of Culture and Social Capital and Organizational Performance by Agency Type (The United States)

\begin{tabular}{|c|c|c|c|c|c|}
\hline & & $\mathrm{N}$ & Mean & $\begin{array}{c}\text { Std. } \\
\text { Deviation }\end{array}$ & Std. Error \\
\hline \multirow[t]{4}{*}{ Culture } & Distributive Agency & 39 & 3.0533 & .27614 & .04422 \\
\hline & Redistributive Agency & 26 & 2.9563 & .27729 & .05438 \\
\hline & Regulatory Agency & 46 & 2.9208 & .25733 & .03794 \\
\hline & Total & 111 & 2.9757 & .27275 & .02589 \\
\hline \multirow[t]{4}{*}{ Social Capital } & Distributive Agency & 39 & 3.5907 & .43905 & .07030 \\
\hline & Redistributive Agency & 25 & 3.6119 & .73444 & .14689 \\
\hline & Regulatory Agency & 46 & 3.3592 & .60756 & .08958 \\
\hline & Total & 110 & 3.4987 & .59375 & .05661 \\
\hline \multirow{4}{*}{$\begin{array}{l}\text { Organizational } \\
\text { Performance }\end{array}$} & Distributive Agency & 39 & 3.5486 & .44301 & .07094 \\
\hline & Redistributive Agency & 25 & 3.5358 & .76937 & .15387 \\
\hline & Regulatory Agency & 46 & 3.3234 & .52640 & .07761 \\
\hline & Total & 110 & 3.4515 & .57016 & .054436 \\
\hline
\end{tabular}


Dummy regression analysis was conducted to examine if agency type has an influence on culture, social capital, and organizational performance in a public sector organization. The results (presented in Table 43) indicate that some factors are significant, excluding Dummy 1 (redistributive agency) in all models. These results suggest that the levels of social capital and organizational performance in a public sector organization are likely to be different according to agency type, except the redistributive agency. Thus, this partially supports Hypothesis 3 .

Table 43: Dummy Regression of Agency Type and Culture and Social Capital and Performance (The United States)

\begin{tabular}{|c|c|c|c|c|c|c|}
\hline \multirow{2}{*}{\multicolumn{2}{|c|}{ Model }} & \multicolumn{2}{|c|}{$\begin{array}{l}\text { Unstandardized } \\
\text { Coefficients }\end{array}$} & \multirow{2}{*}{$\begin{array}{c}\text { Standardized } \\
\text { Coefficients }\end{array}$} & \multirow[t]{2}{*}{$\mathrm{t}$} & \multirow[t]{2}{*}{ Sig. } \\
\hline & & $\mathrm{B}$ & $\begin{array}{l}\text { Std. } \\
\text { Error }\end{array}$ & & & \\
\hline \multirow[t]{3}{*}{ Culture } & Constant & 3.053 & .043 & & 70.954 & .000 \\
\hline & Dummy1 & -.097 & .068 & -.151 & -1.426 & .157 \\
\hline & Dummy2 & -.133 & .058 & -.240 & -2.266 & .025 \\
\hline \multirow[t]{3}{*}{ Social Capital } & Constant & 3.591 & .094 & & 38.194 & .000 \\
\hline & Dummy1 & -.021 & .150 & -.015 & .141 & .888 \\
\hline & Dummy2 & -.231 & .128 & -.193 & -1.811 & .073 \\
\hline \multirow{3}{*}{$\begin{array}{c}\text { Organizational } \\
\text { performance }\end{array}$} & Constant & 3.549 & .090 & & 39.237 & .000 \\
\hline & Dummy1 & -.013 & .145 & -.009 & -.088 & .930 \\
\hline & Dummy2 & -.225 & .123 & -.196 & -1.832 & .070 \\
\hline
\end{tabular}

I conducted moderated regression analysis to examine if culture impacts the process by which social capital influences organizational performance. The results are presented in Tables 44 and 45. The explanatory power of Model 3 shows improvement from Models 1 and 2. 
The values of $\mathrm{R}^{2}$ increase when an interacting variable is added in Model 3, although it is a delicate difference. Therefore, the moderator variable - culture - has a positive effect on organizational performance. The effect of social capital on organizational performance is .666 and the effect when the 'culture' moderator variable is added in the model is .681 . The effect of social capital on organizational performance and the effect of culture on organizational performance is significant at the level of $(p \leq .05)$. However, there is no moderating effect on the process of the effect of social capital on organizational performance because the significant $\mathrm{F}$ change of culture moderator variable is $\mathrm{p}=.324$. Thus, these results do not support Hypothesis 2 .

Table 44: Effect of Social Capital on Organizational Performance, Moderator Regression - Model Summary ${ }^{\mathrm{d}}$ (The United States)

\begin{tabular}{|c|c|c|c|c|c|c|c|c|c|c|}
\hline \multirow[t]{2}{*}{ Model } & \multirow[t]{2}{*}{$\mathrm{R}$} & \multirow[t]{2}{*}{$\mathrm{R}^{2}$} & \multirow[t]{2}{*}{ Adj. $R^{2}$} & \multirow[t]{2}{*}{ SE } & \multicolumn{5}{|c|}{ Change Statistics } & \multirow{2}{*}{$\begin{array}{l}\text { Durbin- } \\
\text { Watson }\end{array}$} \\
\hline & & & & & $\begin{array}{c}\mathrm{R} 2 \\
\text { Change }\end{array}$ & $\begin{array}{c}\mathrm{F} \\
\text { Change }\end{array}$ & df1 & df2 & $\begin{array}{l}\text { Sig. F } \\
\text { Change }\end{array}$ & \\
\hline 1 & $.816^{\mathrm{a}}$ & .666 & .663 & .33093 & .666 & 215.562 & 1 & 108 & .000 & \\
\hline 2 & $.823^{\mathrm{b}}$ & .678 & .672 & .32662 & .012 & 3.864 & 1 & 107 & .052 & \\
\hline 3 & $.825^{\mathrm{c}}$ & .681 & .672 & .32665 & .003 & .984 & 1 & 106 & .324 & 1.841 \\
\hline
\end{tabular}

a. Predictors: (Constant), Social Capital

b. Predictors: (Constant), Social Capital, Culture

c. Predictors: (Constant), Social Capital, Culture, Social Capital*Culture

d. Dependent Variable: Organizational Performance 
Table 45: Effect of Social Capital on Organizational Performance, Moderator Regression - Coefficient ${ }^{\mathrm{a}}$ (The United States)

\begin{tabular}{|c|c|c|c|c|c|c|}
\hline \multirow{2}{*}{\multicolumn{2}{|c|}{ Model }} & \multicolumn{2}{|c|}{$\begin{array}{l}\text { Unstandardized } \\
\text { coefficient }\end{array}$} & $\begin{array}{l}\text { Standardized } \\
\text { coefficient }\end{array}$ & \multirow[t]{2}{*}{$\mathrm{t}$} & \multirow[t]{2}{*}{$\mathrm{p}$} \\
\hline & & $\mathrm{B}$ & SE & Beta & & \\
\hline \multirow[t]{2}{*}{1} & (Constant) & .709 & .189 & & 3.744 & .000 \\
\hline & Social Capital & .784 & .053 & .816 & 14.682 & .000 \\
\hline \multirow[t]{3}{*}{2} & (Constant) & .105 & .360 & & .293 & .770 \\
\hline & Social Capital & .761 & .054 & .792 & 14.089 & .000 \\
\hline & Culture & .230 & .117 & .111 & 1.966 & .052 \\
\hline \multirow[t]{4}{*}{3} & (Constant) & 1.981 & 1.925 & & 1.029 & .306 \\
\hline & Social Capital & .240 & .527 & .250 & .456 & .649 \\
\hline & Culture & -.422 & .668 & -.202 & -.631 & .529 \\
\hline & Culture*Social Capital & .180 & .182 & .684 & .992 & .324 \\
\hline
\end{tabular}

a. Dependent variable: Organizational Performance

\section{Comparative Analysis (South Korea and The United States)}

\section{Sample Characteristics}

This section compares the results from the South Korean city with those from the U.S. city. Table 46 shows that out of 407 surveys distributed to three types of agencies, I received 294 usable and valid responses that are analyzed in this study. The overall response rate is $72.2 \%$, with the highest response rate $(81.3 \%)$ coming from departments engaged in redistributive policies.

Table 46: Survey Distribution and Responses (Total)

\begin{tabular}{|c|c|c|c|}
\hline Type of Agencies & Distribution & Responses & Response Rate \\
\hline Distributive agency & 153 & 112 & $73.2 \%$ \\
\hline Redistributive agency & 96 & 78 & $81.3 \%$ \\
\hline Regulatory agency & 158 & 104 & $65.8 \%$ \\
\hline Total & 407 & 294 & $72.2 \%$ \\
\hline
\end{tabular}


The demographic information of survey respondents is presented in Table 47. Males compose $63.3 \%$ of all respondents while females compose $36.8 \%$. For education, most respondents $(60.5 \%)$ are college graduates, followed by $12.7 \%$ of respondents holding a master's degree and $12.7 \%$ holding a 2-year associate's degree, $8.6 \%$ being high school graduates, and $2.7 \%$ with doctorate degrees. Over $88 \%$ of the respondents have some form of college education. Regarding departments, distributive agency is the largest group with $38.1 \%$, followed by regulatory agency $(35.4 \%)$, and redistributive agency $(26.5 \%)$. It is evenly distributed.

Table 47: Descriptive Statistics of Survey Respondents (Total)

\begin{tabular}{|l|c|c|c|}
\hline \multicolumn{1}{|c|}{} & Frequency & Percent \\
\hline Gender & Male & 184 & 63.3 \\
& Female & 107 & 36.8 \\
& Total & 291 & 100 \\
\hline Education & High school graduate & 25 & 8.6 \\
& 2-year associate degree & 37 & 12.7 \\
& College graduate & 176 & 60.5 \\
& Master's degree & 37 & 12.7 \\
& Doctorate degree & 8 & 2.7 \\
& Others & 8 & 2.7 \\
& Total & 291 & 100 \\
\hline Department & Distributive agency & 112 & 38.1 \\
& Redistributive agency & 78 & 26.5 \\
& Regulatory agency & 104 & 35.4 \\
& Total & 294 & 100 \\
\hline
\end{tabular}

Regarding age, respondents' average is about 44 years with a standard deviation of 10.35. The minimum and maximum for age are 23 and 69 years old, respectively. In terms of work-experience, the mean for full-time work experience is 19.44 with a standard deviation of 11.64 and the mean for public sector work-experience is 14.90 with 
a standard deviation of 10.49 . The mean of years-working in the current position is 6.48 with a standard deviation of 7.98 .

Table 47: Descriptive Statistics of Survey Respondents (Total) - continued

\begin{tabular}{|c|c|c|c|c|c|c|}
\hline \multicolumn{2}{|c|}{} & $\mathrm{N}$ & Minimum & Maximum & Mean & SD \\
\hline \multicolumn{2}{|c|}{ Age } & 287 & 23 & 69 & 44.2265 & 10.35595 \\
\hline Working & Full-time & 287 & .00 & 50 & 19.4446 & 11.64799 \\
Year & Public sector & 286 & .00 & 50 & 14.9024 & 10.49179 \\
& Current Position & 288 & .00 & 50 & 6.4872 & 7.98129 \\
& Valid N & 286 & & & & \\
\hline
\end{tabular}

\section{Factor Analysis and Reliability Analysis}

I conducted factor analysis to reduce the number of items to a small number of underlying groups of items called factors. Overall factor analysis with varimax rotation was conducted to test the unidimensionality of the items. Then, reliability analysis was conducted to assess the degree of consistency between multiple measurements of a variable. The results are represented in Table 48. Cronbach's alpha of all variables are over .750, which is acceptable. The value of Cronbach's alpha for social capital (.934), is the highest, followed by organizational performance (.933), and culture (.779).

Table 48: Factor Analysis and Reliability Analysis (Total)

\begin{tabular}{|c|c|c|c|c|}
\hline Variable & Factor & & $\begin{array}{l}\text { Factor } \\
\text { Loadings }\end{array}$ & $\begin{array}{l}\text { Cront } \\
\text { Alpha }\end{array}$ \\
\hline \multirow[t]{5}{*}{ Culture } & \multirow[t]{5}{*}{ Power Distance } & PD1 & .693 & \multirow{5}{*}{.750} \\
\hline & & PD2 & .581 & \\
\hline & & PD3 & .683 & \\
\hline & & PD4 & .673 & \\
\hline & & PD5 & .709 & \\
\hline
\end{tabular}




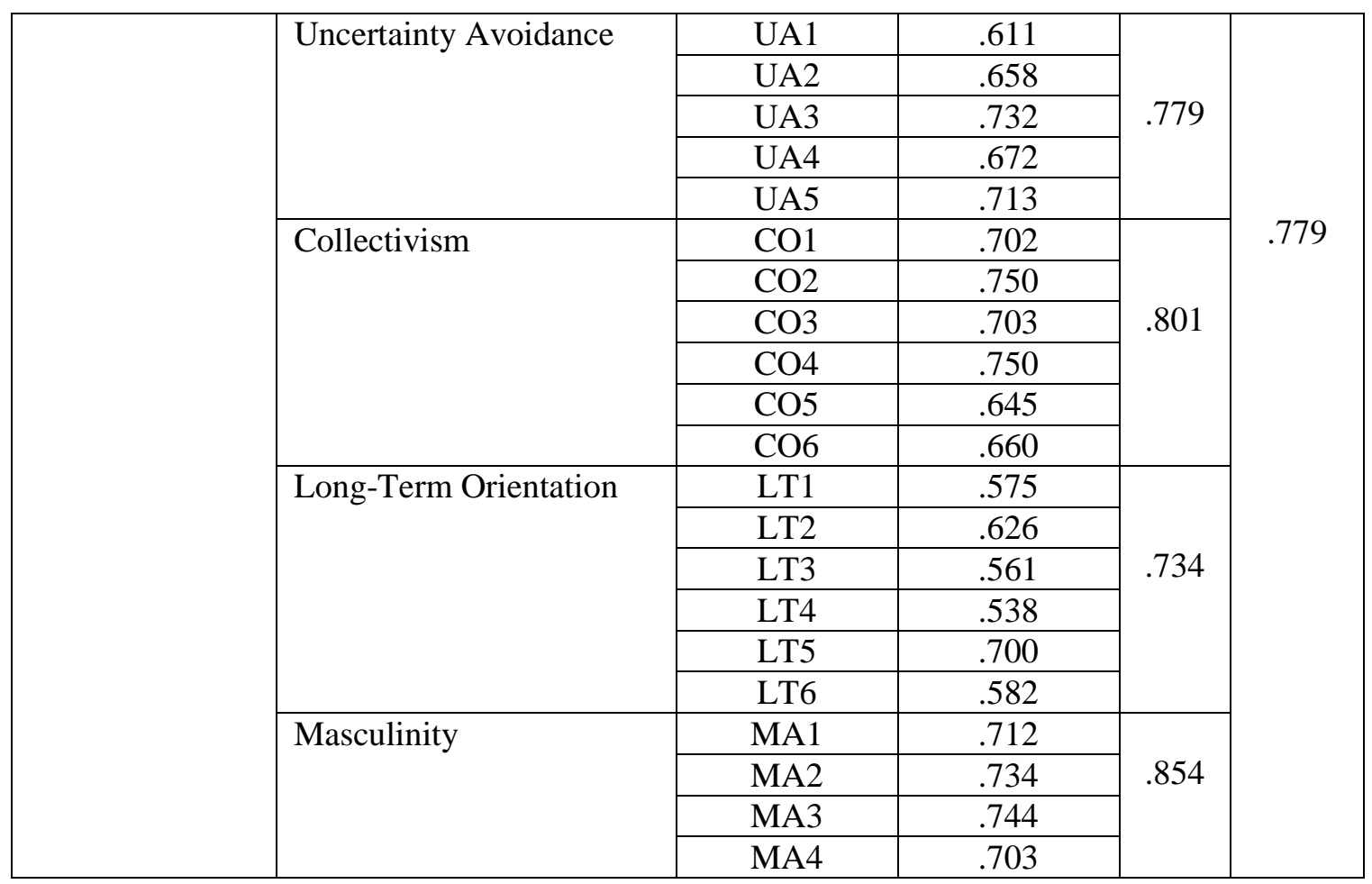

Table 48: Factor Analysis and Reliability Analysis (Total)- continued

\begin{tabular}{|c|c|c|c|c|c|}
\hline Variable & \multicolumn{2}{|l|}{ Factor } & \multirow{2}{*}{$\begin{array}{l}\begin{array}{l}\text { Factor } \\
\text { Loadings }\end{array} \\
.728 \\
\end{array}$} & \multicolumn{2}{|c|}{$\begin{array}{l}\text { Cronbach's } \\
\text { Alpha }\end{array}$} \\
\hline \multirow[t]{17}{*}{ Social Capital } & \multirow{4}{*}{ Structural social capital } & SSC1 & & \multirow{4}{*}{.806} & \\
\hline & & $\mathrm{SSC} 2$ & .793 & & \\
\hline & & SSC3 & .672 & & \\
\hline & & SSC4 & .676 & & \\
\hline & \multirow[t]{9}{*}{ Relational social capital } & $\mathrm{RSC} 1$ & .621 & \multirow{9}{*}{.895} & \\
\hline & & RSC2 & .738 & & \\
\hline & & $\mathrm{RSC} 3$ & .693 & & \\
\hline & & RSC4 & .681 & & \\
\hline & & RSC5 & .704 & & .934 \\
\hline & & RSC6 & .605 & & \\
\hline & & RSC7 & .787 & & \\
\hline & & RSC8 & .721 & & \\
\hline & & RSC9 & .716 & & \\
\hline & \multirow[t]{4}{*}{ Cognitive social capital } & $\mathrm{CSC} 1$ & .702 & \multirow{4}{*}{.865} & \\
\hline & & $\mathrm{CSC} 2$ & .698 & & \\
\hline & & $\mathrm{CSC} 3$ & .606 & & \\
\hline & & $\mathrm{CSC} 4$ & .673 & & \\
\hline
\end{tabular}


Table 48: Factor Analysis and Reliability Analysis (Total) - continued

\begin{tabular}{|c|c|c|c|c|c|}
\hline Variable & \multicolumn{2}{|l|}{ Factor } & $\begin{array}{l}\text { Factor } \\
\text { Loadings }\end{array}$ & \multicolumn{2}{|c|}{$\begin{array}{l}\text { Cronbach's } \\
\text { Alpha }\end{array}$} \\
\hline \multirow{13}{*}{$\begin{array}{l}\text { Organizational } \\
\text { Performance }\end{array}$} & \multirow[t]{4}{*}{ Efficiency } & EFIC1 & .704 & \multirow{4}{*}{.876} & \multirow{13}{*}{.933} \\
\hline & & EFIC2 & .665 & & \\
\hline & & EFIC3 & .775 & & \\
\hline & & EFIC4 & .773 & & \\
\hline & \multirow[t]{3}{*}{ Effectiveness } & EFTV1 & .690 & \multirow{3}{*}{.876} & \\
\hline & & EFTV2 & .743 & & \\
\hline & & EFTV3 & .756 & & \\
\hline & \multirow[t]{3}{*}{ Responsiveness } & RESP1 & .776 & \multirow{3}{*}{.853} & \\
\hline & & RESP2 & .821 & & \\
\hline & & RESP3 & .755 & & \\
\hline & \multirow[t]{3}{*}{ Equity } & EQTY1 & .782 & \multirow{3}{*}{.938} & \\
\hline & & EQTY2 & .791 & & \\
\hline & & EQTY3 & .765 & & \\
\hline
\end{tabular}

*Extraction Method: Maximum Likelihood

*12 factors extracted

With factor analysis, the data matrix should have sufficient correlations to justify the application of factor analysis. As presented in Table 49, the value for KMO is .903, which is acceptable and Bartlett's test of sphericity is significant $(p \leq .001)$, which means that sufficient correlations exist among the items, allowing the study to proceed with factor analysis.

Table 49: KMO and Bartlett's Test (Total)

\begin{tabular}{|l|l|r|}
\hline \multicolumn{2}{|l|}{ Kaiser-Meyer-Olkin Measure of Sampling Adequacy. } & .903 \\
\hline Bartlett's Test of Sphericity & Approx. Chi-Square & 9677.398 \\
& df & 1540 \\
& Sig. & .000 \\
\hline
\end{tabular}


As presented in Table 50, Goodness-of Test is significant at the level of ( $p$ $\leq .001)$.

Table 50: Goodness-of-Test (Total)

\begin{tabular}{|c|c|c|}
\hline Chi-Square & df & Sig. \\
\hline 1295.048 & 890 & .000 \\
\hline
\end{tabular}

\section{Descriptive Statistics}

Table 51 summarizes the mean and standard deviation by factors. Of the culture factors, the mean for uncertainty avoidance is 4.02 with a standard deviation of .50 . Higher level of mean score is more likely to avoid uncertainty. For social capital factors, the mean for cognitive social capital is the highest, followed by structural social capital (3.5435) and relational social capital (3.3225). For organizational performance, the mean score for responsiveness is the most prevalent with 3.73 , followed by effectiveness (3.63), efficiency (3.54), and equity (3.50). The mean for equity is relatively low when compared to other factors.

Table 51: Mean and Standard Deviation by Factors (Total)

\begin{tabular}{|l|l|c|c|c|}
\hline \multicolumn{1}{|c|}{ Variable } & \multicolumn{1}{|c|}{ Factor } & N & Mean & $\begin{array}{c}\text { Std. } \\
\text { Deviation }\end{array}$ \\
\hline \multirow{5}{*}{ Culture } & Power Distance & 291 & 2.1546 & .62643 \\
\cline { 2 - 5 } & Uncertainty Avoidance & 293 & 4.0287 & .50558 \\
\cline { 2 - 5 } & Collectivism & 293 & 3.1656 & .58990 \\
\cline { 2 - 5 } & Long-Term Orientation & 292 & 3.7963 & .50191 \\
\cline { 2 - 5 } & Masculinity & 294 & 2.4949 & .83389 \\
\hline Social Capital & Structural social capital & 293 & 3.5435 & .63941 \\
\cline { 2 - 5 } & Relational social capital & 288 & 3.3225 & .58523 \\
\cline { 2 - 5 } Performance & Cognitive social capital & 290 & 3.6879 & .65736 \\
\cline { 2 - 5 } & Efficiency & 293 & 3.5486 & .64004 \\
\cline { 2 - 5 } & Effectiveness & 292 & 3.6358 & .65817 \\
\cline { 2 - 5 } & Responsiveness & 292 & 3.7317 & .62342 \\
\cline { 2 - 5 } & Equity & 290 & 3.5092 & .84525 \\
\hline
\end{tabular}


Mean and standard deviation by variable are presented in Table 52. First, the means score for culture is 3.13 with a standard deviation of 0.33 . Second, the mean score for social capital is 3.52 with a standard deviation of 0.56 . Lastly, the mean score for organizational performance is 3.61 .

Table 52: Mean and Standard Deviation by Variables (Total)

\begin{tabular}{|c|c|c|c|}
\hline Variable & $\mathrm{N}$ & Mean & Std. Deviation \\
\hline Culture & 294 & 3.1304 & .33842 \\
\hline Social Capital & 293 & 3.5206 & .56003 \\
\hline $\begin{array}{c}\text { Organizational } \\
\text { Performance }\end{array}$ & 293 & 3.6109 & .57830 \\
\hline
\end{tabular}

\section{Correlation Analysis}

Correlation analysis was conducted to examine the basic relationships among all the study variables and to check for possible multicollinearity problems among the variables. The correlation matrix (presented in Table 53) examined the relationships among the variables' indices of culture, social capital, and organizational performance. This study aimed to determine if social capital affected organizational performance. The results indicate that such effect is apparent. All Pearson's r coefficients range from .482 to 677 , indicating strong, positive and significant relationships $(p \leq .01)$. The correlation between cognitive social capital and effectiveness represents the strongest correlation (.677). The second strongest relationship is between relational social capital and equity with a coefficient of .675 . The third strongest relationship is between cognitive social capital and equity with a coefficient of .669. Equity has strong and positive relationships 
with social capital variables. The results indicate that organizations with higher levels of social capital are likely to have higher levels of organizational performance.

Table 53: Correlations of Culture and Social Capital and Organizational Performance (Total)

\begin{tabular}{|c|c|c|c|c|c|c|c|c|c|c|c|c|}
\hline & PD & UA & $\mathrm{CO}$ & LT & MA & SSC & RSC & CSC & EFIC & EFTV & RESP & EQTY \\
\hline PD & 1 & & & & & & & & & & & \\
\hline UA & $-.187 * *$ & 1 & & & & & & & & & & \\
\hline $\mathrm{CO}$ & -.069 & $.238^{* *}$ & 1 & & & & & & & & & \\
\hline LT & $-.147 *$ & $.484 * *$ & $.291^{* *}$ & 1 & & & & & & & & \\
\hline MA & .456 & -.004 & .076 & .093 & 1 & & & & & & & \\
\hline SSC & .044 & $.249 * *$ & $.209 * *$ & $244 * *$ & .103 & 1 & & & & & & \\
\hline RSC & -.029 & $.199 * *$ & $.203^{* * *}$ & $.314 * *$ & .005 & $.719 * *$ & 1 & & & & & \\
\hline $\mathrm{CSC}$ & .032 & $.321 * *$ & $.227 * *$ & $.372^{* * *}$ & .099 & $.684 * *$ & $.674 * *$ & 1 & & & & \\
\hline EFIC & .025 & $.377 * *$ & $.221 * *$ & .430 ** & $.175^{* * *}$ & $.565 * *$ & $.482 * *$ & $.633 * *$ & 1 & & & \\
\hline EFTV & .027 & $.333^{* *}$ & $.220 * *$ & $.398^{* * *}$ & $.176^{* * *}$ & $.566^{* * *}$ & $.578^{* * *}$ & $.677 * *$ & .756 ** & 1 & & \\
\hline RESP & -.046 & $.250 * *$ & $.149^{*}$ & $.330 * *$ & .091 & $.493 * *$ & $.536^{* * *}$ & $.579 * *$ & $.506^{* *}$ & $.547 * *$ & 1 & \\
\hline EQTY & $.133^{*}$ & $.285^{* *} *$ & $.256 * *$ & $.359 * *$ & $.196^{* *}$ & $.653 * *$ & $.675^{* *}$ & $.669 * *$ & $.606^{* *}$ & $.668 * *$ & $.508 * *$ & 1 \\
\hline
\end{tabular}

**. Correlation is significant at the 0.01 level (2-tailed).

*. Correlation is significant at the 0.05 level (2-tailed).

Table 53: Correlations of Culture and Social Capital and Organizational Performance (Total) - continued

\begin{tabular}{|c|r|r|r|r|r|r|r|}
\hline & \multicolumn{1}{c|}{ PD } & \multicolumn{1}{c|}{ UA } & \multicolumn{1}{c|}{ CO } & \multicolumn{1}{l|}{ LT } & MA & SC & OP \\
\hline PD & 1 & & & & & & \\
\hline UA & $-.187^{* *}$ & 1 & & & & & \\
\hline CO & -.069 & $.238^{* *}$ & 1 & & & & \\
\hline LT & $-.147^{*}$ & $.484^{* *}$ & $.291^{* *}$ & 1 & & & \\
\hline MA & $.456^{* *}$ & -.004 & .076 & .093 & 1 & & \\
\hline SC & .027 & $.287^{* *}$ & $.245^{* *}$ & $.346^{* *}$ & .081 & 1 & \\
\hline OP & .054 & $.364^{* *}$ & $.254^{* *}$ & $.451^{* *}$ & $.202^{* *}$ & $.801^{* *}$ & 1 \\
\hline
\end{tabular}

**. Correlation is significant at the 0.01 level (2-tailed).

*. Correlation is significant at the 0.05 level (2-tailed). 
I conducted a t-test to examine if there are differences between males and females in the mean for the all factors used in this study. The results are presented in Table 54. The mean differences for most factors are not statistically significant, except power distance, collectivism/individualism, masculinity, and equity. The mean differences for power distance, collectivism/individualism, masculinity, and equity are significant at the level of $\mathrm{p}$-value $(p \leq .05)$. The higher power distance score of male respondents indicates that people are accepting of a hierarchical order.

However, the lower power distance score means that female respondents value being independent and having equal rights. The male respondents are more likely to be collectivistic and masculine while the female respondents are more individualistic and feminine. For equity, the mean score of male respondents (3.63) is higher than that of female respondents (3.30).

Table 54: t-test of Gender and Factors (Total)

\begin{tabular}{|c|c|c|c|c|c|c|}
\hline Variable & \multicolumn{2}{|c|}{ Factor } & Mean & Std. & t-value & p-value \\
\hline \multirow[t]{10}{*}{ Culture } & \multirow[t]{2}{*}{ PD } & Male & 2.2404 & .68733 & \multirow[t]{2}{*}{3.170} & \multirow[t]{2}{*}{.002} \\
\hline & & Female & 2.0000 & (47798 & & \\
\hline & \multirow[t]{2}{*}{ UA } & Male & 4.0208 & .55133 & \multirow[t]{2}{*}{-.450} & \multirow[t]{2}{*}{.653} \\
\hline & & Female & 4.0486 & .42368 & & \\
\hline & \multirow[t]{2}{*}{$\mathrm{CO}$} & Male & 3.2420 & .60601 & \multirow[t]{2}{*}{2.862} & \multirow[t]{2}{*}{.005} \\
\hline & & Female & 3.0377 & .54738 & & \\
\hline & \multirow[t]{2}{*}{ LT } & Male & 3.8172 & .53544 & \multirow[t]{2}{*}{901} & \multirow[t]{2}{*}{.368} \\
\hline & & Female & 3.7619 & .43661 & & \\
\hline & \multirow[t]{2}{*}{ MA } & Male & 2.7391 & .82433 & \multirow[t]{2}{*}{7.081} & \multirow[t]{2}{*}{.000} \\
\hline & & Female & 2.0724 & .67991 & & \\
\hline \multirow{2}{*}{\multicolumn{2}{|c|}{ Total }} & Male & 3.2128 & .35606 & \multirow[t]{2}{*}{5.743} & \multirow[t]{2}{*}{.000} \\
\hline & & Female & 2.9840 & .25088 & & \\
\hline
\end{tabular}




\begin{tabular}{|c|c|c|c|c|c|c|}
\hline \multirow[t]{6}{*}{ Social Capital } & \multirow[t]{2}{*}{$\mathrm{SSC}$} & Male & 3.5761 & .63670 & \multirow[t]{2}{*}{.979} & \multirow[t]{2}{*}{.328} \\
\hline & & Female & 3.5000 & .64336 & & \\
\hline & \multirow[t]{2}{*}{ RSC } & Male & 3.3694 & .58480 & \multirow[t]{2}{*}{1.624} & \multirow[t]{2}{*}{.105} \\
\hline & & Female & 3.2531 & .57802 & & \\
\hline & \multirow[t]{2}{*}{ CSC } & Male & 3.6954 & .67002 & \multirow[t]{2}{*}{.090} & \multirow[t]{2}{*}{.928} \\
\hline & & Female & 3.6881 & .63717 & & \\
\hline \multirow{2}{*}{\multicolumn{2}{|c|}{ Total }} & Male & 3.5465 & .56631 & \multirow[t]{2}{*}{.848} & \multirow[t]{2}{*}{.397} \\
\hline & & Female & 3.4878 & .54646 & & \\
\hline \multirow{8}{*}{$\begin{array}{l}\text { Organizational } \\
\text { Performance }\end{array}$} & \multirow[t]{2}{*}{ EFCY } & Male & 3.5938 & .65836 & \multirow[t]{2}{*}{1.446} & \multirow[t]{2}{*}{.149} \\
\hline & & Female & 3.4813 & .60530 & & \\
\hline & \multirow[t]{2}{*}{ EFTV } & Male & 3.6486 & .67005 & \multirow[t]{2}{*}{.283} & \multirow[t]{2}{*}{.777} \\
\hline & & Female & 3.6258 & .64028 & & \\
\hline & \multirow[t]{2}{*}{ RESP } & Male & 3.7717 & .60443 & \multirow[t]{2}{*}{1.261} & \multirow[t]{2}{*}{.208} \\
\hline & & Female & 3.6761 & .65134 & & \\
\hline & \multirow[t]{2}{*}{ EQTY } & Male & 3.6337 & .80064 & \multirow[t]{2}{*}{3.227} & \multirow[t]{2}{*}{.001} \\
\hline & & Female & 3.3050 & .88744 & & \\
\hline \multirow{2}{*}{\multicolumn{2}{|c|}{ Total }} & Male & 3.6656 & .57538 & \multirow[t]{2}{*}{.868} & \multirow[t]{2}{*}{.051} \\
\hline & & Female & 3.5278 & .57493 & & \\
\hline
\end{tabular}

A t-test regarding city and factors was conducted to see if there are differences between the two countries, as Hofstede mentioned, in terms of culture. According to Hofstede's framework, these countries contrast strongly on important cultural characteristics such as power distance, uncertainty avoidance, collectivism, long-term orientation, and masculinity. As presented in Table 55, there are differences between the two countries in terms of culture ${ }^{11}$, which means that Hofstede's results remain relevant.

However, only the mean difference for collectivism/individualism is not significant. According to Hofstede's results, the United States is more individualistic than South Korea. Results of the present study show that the mean score for the city of Omaha

\footnotetext{
${ }^{11}$ See Appendix 2 for further elaboration of county-level values and city-level values of culture dimensions.
} 
is slightly higher than Wonju city—meaning that the United States is more individualistic, though this is not statistically significant. This result can be explained by globalization, as South Korea is gradually exposed to foreign cultures. As a result, the United States has a lower power distance, a lower uncertainty avoidance, a short-term orientation, and more masculinity compared to South Korea. Regarding social capital, the differences of mean scores between the two cities are not significant. For organizational performance, the mean differences of all factors are significant except responsiveness. That is, the mean for Wonju city is higher than the city of Omaha regarding efficiency, effectiveness, and equity. In total, the mean of social capital and organizational performance for Wonju city is higher than that of Omaha.

Table 55: t-test of City and Factors (Total)

\begin{tabular}{|c|c|c|c|c|c|c|}
\hline Variable & \multicolumn{2}{|c|}{ Factor } & Mean & Std. & t-value & p-value \\
\hline \multirow{10}{*}{ Culture } & \multirow[t]{2}{*}{ PD } & Omaha & 2.0378 & .56730 & \multirow[t]{2}{*}{-2.521} & \multirow{2}{*}{.012} \\
\hline & & Wonju & 2.2267 & .65139 & & \\
\hline & \multirow[t]{2}{*}{ UA } & Omaha & 3.8865 & .55571 & \multirow[t]{2}{*}{-3.847} & \multirow[t]{2}{*}{.000} \\
\hline & & Wonju & 4.1154 & .45248 & & \\
\hline & \multirow[t]{2}{*}{$\mathrm{CO}$} & Omaha & 3.1970 & .56460 & \multirow[t]{2}{*}{.710} & \multirow[t]{2}{*}{.478} \\
\hline & & Wonju & 3.1465 & .60555 & & \\
\hline & \multirow[t]{2}{*}{ LT } & Omaha & 3.6219 & .45250 & \multirow[t]{2}{*}{-4.825} & \multirow[t]{2}{*}{.000} \\
\hline & & Wonju & 3.9033 & .50186 & & \\
\hline & \multirow[t]{2}{*}{ MA } & Omaha & 2.1351 & .79614 & \multirow[t]{2}{*}{-6.108} & \multirow[t]{2}{*}{.000} \\
\hline & & Wonju & 2.7131 & .78074 & & \\
\hline \multirow{2}{*}{\multicolumn{2}{|c|}{ Total }} & Omaha & 2.9757 & .27275 & \multirow[t]{2}{*}{-6.584} & \multirow[t]{2}{*}{.000} \\
\hline & & Wonju & 3.2275 & .34012 & & \\
\hline \multirow[t]{5}{*}{ Social Capital } & \multirow[t]{2}{*}{ SSC } & Omaha & 3.5568 & .65109 & \multirow[t]{2}{*}{.276} & \multirow[t]{2}{*}{.783} \\
\hline & & Wonju & 3.5355 & .63395 & & \\
\hline & \multirow[t]{2}{*}{ RSC } & Omaha & 3.3393 & .62351 & \multirow[t]{2}{*}{.382} & \multirow[t]{2}{*}{.703} \\
\hline & & Wonju & 3.3121 & .56183 & & \\
\hline & $\mathrm{CSC}$ & Omaha & 3.6000 & .71853 & -1.787 & .075 \\
\hline
\end{tabular}




\begin{tabular}{|c|c|c|c|c|c|c|}
\hline & & Wonju & 3.7417 & .61289 & & \\
\hline \multirow{2}{*}{\multicolumn{2}{|c|}{ Total }} & Omaha & 3.4987 & .59375 & \multirow[t]{2}{*}{-.522} & \multirow[t]{2}{*}{.602} \\
\hline & & Wonju & 3.5343 & .53904 & & \\
\hline \multirow{8}{*}{$\begin{array}{l}\text { Organizational } \\
\text { Performance }\end{array}$} & \multirow[t]{2}{*}{ EFCY } & Omaha & 3.2818 & .57480 & \multirow[t]{2}{*}{-5.837} & \multirow[t]{2}{*}{.000 } \\
\hline & & Wonju & 3.7090 & .62489 & & \\
\hline & \multirow[t]{2}{*}{ EFTV } & Omaha & 3.5000 & .67086 & \multirow[t]{2}{*}{-2.773} & \multirow[t]{2}{*}{.006} \\
\hline & & Wonju & 3.7179 & .63830 & & \\
\hline & \multirow[t]{2}{*}{ RESP } & Omaha & 3.6667 & 66667 & \multirow[t]{2}{*}{-1.389} & \multirow[t]{2}{*}{.166} \\
\hline & & Wonju & 3.7711 & 59420 & & \\
\hline & \multirow[t]{2}{*}{ EQTY } & Omaha & 3.3576 & .85398 & \multirow[t]{2}{*}{-2.408} & \multirow[t]{2}{*}{.017} \\
\hline & & Wonju & 3.6019 & .82864 & & \\
\hline \multirow{2}{*}{\multicolumn{2}{|c|}{ Total }} & Omaha & 3.4515 & .57016 & \multirow[t]{2}{*}{-3.757} & \multirow[t]{2}{*}{.000} \\
\hline & & Wonju & 3.7089 & .56273 & & \\
\hline
\end{tabular}

\section{Regression Analysis}

Ordinary least squares (OLS) multiple regression analysis was conducted to test the hypotheses. OLS for the efficiency, effectiveness, responsiveness, and equity indices are presented in Table 56. The results indicate that most models are statistically significant, with adjusted $\mathrm{R}^{2}$ scores ranging from .365 for responsiveness index to .650 for total dependent variables. Adjusted $\mathrm{R}^{2}$ scores for the remaining indexes are .431 for efficiency, .481 for effectiveness, and .552 for equity. These results suggest that a public sector organization with higher levels of social capital is more likely to have higher levels of organizational performance. In particular, cognitive social capital has a statistically positive and strong effect on all dependent variables. That is, the data supports Hypothesis 1. 
Table 56: Effect of Social Capital on Organizational Performance, Linear Regression (Total)

\begin{tabular}{|c|c|c|c|c|c|c|c|}
\hline & \multicolumn{6}{|c|}{ Independent Variables } \\
\hline & & \multicolumn{2}{|c|}{ Structural SC } & \multicolumn{2}{|c|}{ Relational SC } & \multicolumn{2}{|c|}{ Cognitive SC } \\
\hline & & $\beta$ & $\mathrm{p}$ & $\beta$ & $\mathrm{p}$ & $\beta$ & $\mathrm{p}$ \\
\hline \multirow{4}{*}{ 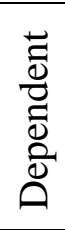 } & Efficiency & .262 & .000 & .018 & .795 & .461 & .000 \\
\hline & Effectiveness & .118 & .079 & .181 & .006 & .468 & .000 \\
\hline & Responsiveness & 086 & .248 & .240 & .001 & .350 & .000 \\
\hline & Equity & .208 & .001 & .314 & .000 & .313 & .000 \\
\hline & Total & .203 & .000 & .231 & .000 & .465 & .000 \\
\hline
\end{tabular}

*Adjusted $\mathrm{R}^{2}$ of Efficiency $=.431$, Adjusted $\mathrm{R}^{2}$ of Effectiveness $=.481$, Adjusted $\mathrm{R}^{2}$ of Responsiveness $=.365$, Adjusted $\mathrm{R}^{2}$ of Equity $=.552$, Adjusted $\mathrm{R}^{2}$ of Total Dependent Variables $=.650$

ANOVA analysis was conducted to test Hypothesis 3 and examine if culture, social capital, and organizational performance in a public sector organization would differ according to agency type. The results (presented in Table 57) show that all factors are statistically significant at the level of $\mathrm{p}$-value $(p \leq .05)$ except power distance and uncertainty avoidance.

Table 57: ANOVA of Agency Type and Factors (Total)

\begin{tabular}{|c|c|c|c|c|c|}
\hline & $\begin{array}{c}\text { Sum of } \\
\text { Squares }\end{array}$ & df & $\begin{array}{c}\text { Mean } \\
\text { Square }\end{array}$ & F & Sig. \\
\hline PD & 1.418 & 2 & .709 & 1.817 & .164 \\
\hline UA & 1.061 & 2 & .530 & 2.091 & .125 \\
\hline CO & 5.417 & 2 & 2.708 & 8.165 & .000 \\
\hline LT & 2.108 & 2 & 1.054 & 4.278 & .015 \\
\hline MA & 9.768 & 2 & 4.884 & 7.327 & .001 \\
\hline Total & $\mathbf{1 . 6 8 3}$ & $\mathbf{2}$ & $\mathbf{. 8 4 2}$ & $\mathbf{7 . 6 9 2}$ &. $\mathbf{0 0 1}$ \\
\hline SSC & 4.458 & 2 & 2.229 & 5.625 & .004 \\
\hline RSC & 4.940 & 2 & 2.470 & 7.541 & .001 \\
\hline
\end{tabular}




\begin{tabular}{|c|c|c|c|c|c|}
\hline CSC & 6.755 & 2 & 3.377 & 8.206 & .000 \\
\hline Total & $\mathbf{6 . 0 1 4}$ & $\mathbf{2}$ & $\mathbf{3 . 0 0 7}$ & $\mathbf{1 0 . 2 1 0}$ & $\mathbf{. 0 0 0}$ \\
\hline EFIC & 3.967 & 2 & 1.983 & 4.974 & .008 \\
\hline EFTV & 7.297 & 2 & 3.649 & 8.879 & .000 \\
\hline RESP & 3.867 & 2 & 1.934 & 5.116 & .007 \\
\hline EQTY & 9.241 & 2 & 4.620 & 6.723 & .001 \\
\hline Total & $\mathbf{5 . 6 1 1}$ & $\mathbf{2}$ & $\mathbf{2 . 8 0 5}$ & $\mathbf{8 . 8 4 6}$ & $\mathbf{. 0 0 0}$ \\
\hline
\end{tabular}

Table 58 presents the means of culture and social capital and organizational performance by agency type. The mean differences for culture, social capital, and organizational performance by agency type are significant. In other words, culture, social capital, and organizational performance differ based on the agency types. For example, distributive agencies have higher levels of social capital and organizational performance when compared to other agencies.

Table 58: Mean of Culture and Social Capital and Organizational Performance by Agency Type (Total)

\begin{tabular}{|c|c|c|c|c|c|}
\hline & & $\mathrm{N}$ & Mean & $\begin{array}{c}\text { Std. } \\
\text { Deviation }\end{array}$ & $\begin{array}{l}\text { Std. } \\
\text { Error }\end{array}$ \\
\hline \multirow[t]{4}{*}{ Culture } & Distributive Agency & 111 & 3.2237 & .34559 & .03280 \\
\hline & Redistributive Agency & 76 & 3.0430 & .28216 & .03237 \\
\hline & Regulatory Agency & 101 & 3.0937 & .34752 & .03458 \\
\hline & Total & 288 & 3.1304 & .33842 & .01994 \\
\hline \multirow[t]{4}{*}{ Social Capital } & Distributive Agency & 108 & 3.6908 & .46718 & .04495 \\
\hline & Redistributive Agency & 76 & 3.5024 & .58213 & .06678 \\
\hline & Regulatory Agency & 101 & 3.3523 & .58556 & .05827 \\
\hline & Total & 285 & 3.5206 & .56003 & .03317 \\
\hline
\end{tabular}




\begin{tabular}{|l|l|c|c|c|c|}
\hline \multirow{4}{*}{ Performance } & Distributive Agency & 112 & 3.7760 & .49908 & .04716 \\
\cline { 2 - 6 } & Redistributive Agency & 75 & 3.5758 & .61939 & .07152 \\
\cline { 2 - 6 } & Regulatory Agency & 102 & 3.4555 & .58586 & .05801 \\
\cline { 2 - 6 } & Total & 289 & 3.6109 & .57830 & .03402 \\
\hline
\end{tabular}

I conducted dummy regression analysis determine if agency type has an influence on culture, social capital, and organizational performance in a public service organization. The results, presented in Table 59, show that all factors are statistically significant $(p \leq .05)$.

For culture, the coefficients of the estimation regression equation are as follows:

Distributive agency: social capital $=3.224-0.181(0)-0.130(0)=3.224$

Redistributive agency: social capital $=3.224-0.181(1)-0.130(0)=3.043$

Regulatory agency: social capital $=3.224-0.181(0)-0.130(1)=3.094$

That is, for culture, distributive agency has an influence as 3.224-0.181(0)$0.130(0)=3.224$, redistributive agency has an influence as $3.224-0.181(1)-0.130(0)=$ 3.043, and regulatory agency has an influence as 3.224 $-0.181(0)-0.130(1)=3.094$.

For social capital, the coefficients of the estimation regression equation are as follows:

Distributive agency: social capital $=3.691-0.188(0)-0.338(0)=3.691$

Redistributive agency: social capital $=3.691-0.188(1)-0.338(0)=3.503$

Regulatory agency: social capital $=3.691-0.188(0)-0.338(1)=3.353$ 
That is, for social capital, distributive agency has an influence as 33.691 $0.188(0)-0.338(0)=3.691$, redistributive agency has an influence as $3.691-0.188(1)-$ $0.338(0)=3.503$, and regulatory agency has an influence as $3.691-0.188(0)-0.338(1)$ $=3.353$.

For organizational performance, the coefficients of the estimation regression equation are as follows:

Distributive agency: social capital $=3.776-0.200(0)-0.321(0)=3.776$

Redistributive agency: social capital $=3.776-0.200(1)-0.321(0)=3.576$

Regulatory agency: social capital $=3.776-0.200(0)-0.321(1)=3.455$

That is, for organizational performance, distributive agency has an influence as $.776-0.200(0)-0.321(0)=3.776$, redistributive agency has an influence as $3.776-$ $0.200(1)-0.321(0)=3.576$, and regulatory agency has an influence as $3.776-0.200(0)$ $-0.321(1)=3.455$.

These results support Hypothesis 3.

Table 59: Dummy Regression of Agency Type and Culture and Social Capital and Performance (Total)

\begin{tabular}{|c|c|r|r|r|r|r|}
\hline \multicolumn{2}{|c|}{ Model } & \multicolumn{2}{|c|}{$\begin{array}{c}\text { Unstandardized } \\
\text { Coefficients }\end{array}$} & $\begin{array}{l}\text { Standardized } \\
\text { Coefficients }\end{array}$ & \multirow{2}{*}{ Sig. } & \\
\cline { 3 - 6 } & \multicolumn{1}{|c|}{$\mathrm{B}$} & $\begin{array}{c}\text { Std. } \\
\text { Error }\end{array}$ & \multicolumn{2}{c|}{ Beta } & & \\
\hline \multirow{2}{*}{ Culture } & Constant & 3.224 & .031 & & 102.675 & .000 \\
& Dummy1 & -.181 & .049 & -.236 & -3.670 & .000 \\
& Dummy2 & -.130 & .045 & -.184 & -2.858 & .005 \\
\hline Social Capital & Constant & 3.691 & .052 & & 70.674 & .000 \\
& Dummy1 & -.188 & .081 & -.149 & -2.318 & .021 \\
& Dummy2 & -.338 & .075 & -.290 & -4.506 & .000 \\
\hline
\end{tabular}




\begin{tabular}{|c|c|r|r|r|r|r|}
\hline Organizational & Constant & 3.776 & .053 & & 70.860 & .000 \\
performance & Dummy1 & -.200 & .084 & -.152 & -2.383 & .018 \\
& Dummy2 & -.321 & .077 & -.265 & -4.159 & .000 \\
\hline
\end{tabular}

A dummy regression of city type and culture and social capital and performance was conducted to see if city type has an influence on culture, social capital, and performance in a public service organization. The results presented in Table 60 show that all factors are statistically significant $(p \leq .001)$, except dummy city for social capital. As a result of dummy regression analysis, for culture, the city of Omaha has an influence as $2.976+.252(0)$ and Wonju city has an influence as $2.976+.252(1)$. For social capital, the city of Omaha has an influence as 3.499+.036(0) and Wonju city has an influence as $3.499+.036(1)$. For organizational performance, the city of Omaha has an influence as $3.452+.257(0)$ and Wonju city has an influence as 3.452+.257(1).

Table 60: Dummy Regression of City Type and Culture and Social Capital and Performance (Total)

\begin{tabular}{|c|c|r|r|r|r|r|}
\hline \multicolumn{2}{|c|}{ Model } & \multicolumn{2}{c|}{$\begin{array}{c}\text { Unstandardized } \\
\text { Coefficients }\end{array}$} & $\begin{array}{l}\text { Standardized } \\
\text { Coefficients }\end{array}$ & \multirow{2}{*}{ Sig. } & \\
\cline { 3 - 6 } & \multicolumn{1}{c|}{ B } & Std. Error & \multicolumn{1}{c|}{ Beta } & & \\
\hline Culture & Constant & 2.976 & .030 & & 99.239 & .000 \\
& Dummy City & .252 & .038 & .363 & 6.584 & .000 \\
\hline Social Capital & Constant & 3.499 & .053 & & 65.439 & .000 \\
& Dummy City & .036 & .068 & .031 & .522 & .602 \\
\hline Organizationa & Constant & 3.452 & .054 & & 64.006 & .000 \\
1 performance & Dummy City & .257 & .069 & .216 & 3.757 & .000 \\
\hline
\end{tabular}


Moderated regression analysis was conducted to test if culture affects the process by which social capital influences organizational performance in a public sector organization. Tables 61 and 62 present the results. The explanatory power of Models 2 and 3 has improved from Model 1. The value of $\mathrm{R}^{2}$ is increased when an interacting variable is added in Model 3 to check moderating effect.

The moderator variable — culture — has a positive effect on organizational performance. As a result, the effect of social capital on organizational performance is .642 and the effect when the 'culture' moderator variable is added in the model is .679. However, significant F change should be checked. The effect of social capital on organizational performance and the effect of culture on organizational performance is significant as $(p \leq .001)$. However, there is no moderating effect on the process of the effect of social capital on organizational performance because the significant $F$ change of culture, moderator variable is $p=.598$. Thus, the results do not support Hypothesis 2 .

Table 61: Effect of Social Capital on Organizational Performance, Moderator Regression - Model Summary ${ }^{\mathrm{d}}$ Total)

\begin{tabular}{|c|c|c|c|c|c|c|c|c|c|c|}
\hline \multirow[t]{2}{*}{ Model } & \multirow[t]{2}{*}{$\mathrm{R}$} & \multirow[t]{2}{*}{$\mathrm{R}^{2}$} & \multirow[t]{2}{*}{ Adj. $R^{2}$} & \multirow[t]{2}{*}{ SE } & \multicolumn{5}{|c|}{ Change Statistics } & \multirow{2}{*}{$\begin{array}{l}\text { Durbin- } \\
\text { Watson }\end{array}$} \\
\hline & & & & & $\begin{array}{c}\mathrm{R} 2 \\
\text { Change }\end{array}$ & F Change & $\begin{array}{c}\mathrm{df} \\
1\end{array}$ & df2 & $\begin{array}{c}\text { Sig. F } \\
\text { Change }\end{array}$ & \\
\hline 1 & $.801^{\mathrm{a}}$ & .642 & .640 & .34615 & .642 & 496.242 & 1 & 277 & .000 & \\
\hline 2 & $.824^{\mathrm{b}}$ & .679 & 677 & .32822 & .037 & 32.091 & 1 & 276 & .000 & \\
\hline 3 & $.824^{\mathrm{c}}$ & .679 & .676 & .32865 & .000 & .278 & 1 & 275 & .598 & 1.720 \\
\hline
\end{tabular}

a. Predictors: (Constant), Social Capital

b. Predictors: (Constant), Social Capital, Culture

c. Predictors: (Constant), Social Capital, Culture, Social Capital*Culture

d. Dependent Variable: Organizational Performance 
Table 62: Effect of Social Capital on Organizational Performance, Moderator Regression - Coefficient $^{\mathrm{a}}$ (Total)

\begin{tabular}{|c|c|c|c|c|c|c|}
\hline \multirow{2}{*}{\multicolumn{2}{|c|}{ Model }} & \multicolumn{2}{|c|}{$\begin{array}{l}\text { Unstandardized } \\
\text { coefficient }\end{array}$} & $\begin{array}{l}\text { Standardized } \\
\text { coefficient }\end{array}$ & \multirow[t]{2}{*}{$\mathrm{t}$} & \multirow[t]{2}{*}{$\mathrm{p}$} \\
\hline & & $\mathrm{B}$ & SE & Beta & & \\
\hline \multirow[t]{2}{*}{1} & (Constant) & .710 & .132 & & 5.382 & .000 \\
\hline & Social Capital & .823 & .037 & .801 & 22.276 & .000 \\
\hline \multirow[t]{3}{*}{2} & (Constant) & -.136 & .195 & & -.697 & .486 \\
\hline & Social Capital & .744 & .037 & .735 & 20.416 & .000 \\
\hline & Culture & .347 & .061 & .204 & 5.665 & .000 \\
\hline \multirow[t]{4}{*}{3} & (Constant) & -.683 & 1.056 & & -.647 & .518 \\
\hline & Social Capital & .905 & .286 & .881 & 3.165 & .002 \\
\hline & Culture & .526 & .345 & .309 & 1.524 & .129 \\
\hline & Culture*Social Capital & -.049 & .092 & -.206 & -.527 & .598 \\
\hline
\end{tabular}

a. Dependent variable: Organizational Performance

\section{Summary}

The previous sections discussed the results of the data collection and presented the analysis results including Korean data, American data, and overall data. This section summarizes the major findings.

South Korea. With respect to the relationship between social capital and organizational performance, results suggest that social capital has a positive influence on organizational performance. Hypothesis 1 is strongly supported; adjusted $\mathrm{R}^{2}$ of efficiency is .509 , adjusted $\mathrm{R}^{2}$ of effectiveness is .487 , adjusted $\mathrm{R}^{2}$ of responsiveness is .291 , adjusted $\mathrm{R}^{2}$ of equity is .627 , and adjusted $\mathrm{R}^{2}$ of total dependent variables is .673 . In more detail, in Hypothesis 1-1, a public sector organization with higher level of structural social capital was hypothesized to have higher levels of organizational performance. The data partially support Hypothesis 1-1, showing that structural social 
capital positively influences efficiency $(\beta=.204, \mathrm{p}<.01)$ and equity $(\beta=.191, \mathrm{p}<.01)$.

Although the coefficient for effectiveness and responsiveness are not statistically significant, the coefficient for effectiveness $(\beta=.133)$ and responsiveness $(\beta=.055)$ have a positive sign for structural social capital. However, structural social capital has a positive influence on total dependent variables or organizational performance $(\beta=.178, p$ $<.01)$.

In Hypothesis 1-2, an organization with higher level of relational social capital was hypothesized to have higher levels of organizational performance. The data support Hypothesis 1-2, showing that relational social capital has a positive influence on effectiveness $(\beta=.158, \mathrm{p}<.01)$, responsiveness $(\beta=.275, \mathrm{p}<.01)$, and equity $(\beta=.268$, $\mathrm{p}<.001)$. Only the coefficient for efficiency is not significant but it has a positive sign for relational social capital. Relational social capital has a positive influence on total dependent variables $(\beta=.224, \mathrm{p}<.001)$. In Hypothesis $1-3$, an organization with higher levels of cognitive social capital was hypothesized to achieve higher levels of organizational performance. The data strongly support Hypothesis 1-3. Cognitive social capital is highly, positively related to efficiency $(\beta=.541, \mathrm{p}<.001)$, effectiveness $(\beta$ $=.495, \mathrm{p}<.001)$, responsiveness $(\beta=.280, \mathrm{p}<.001)$, and equity $(\beta=.427, \mathrm{p}<.001)$.

In Hypothesis 2, the effect of social capital of public service organizations on organizational performance was hypothesized to differ according to level of culture. Moderator regression analysis shows that the data do not support Hypothesis 2 . The results show that the effect of social capital on organizational performance and the effect of culture on organizational performance is significant $(\mathrm{p}<.001)$. However, there is no 
moderating effect on the process of the effect of social capital on organizational performance, indicating that the significant $\mathrm{F}$ change of culture is $\mathrm{p}=.110$.

In Hypothesis 3, culture, social capital, and organizational performance in a public sector organization were hypothesized to differ according to agency type. The data support Hypothesis 3. The results show that all factors are statistically significant ( $\mathrm{p}$ $<.001$ ), except Dummy 2 - regulatory agency —in the culture model. For the culture model, distributive agency and redistributive agency have an influence as 3.316 and 3.328 , respectively. For the social capital model, distributive agency (3.747) has the highest level of social capital, followed by redistributive agency (3.448) and regulatory agency (3.346). In terms of organizational performance, like social capital, distributive agency (3.897) has the highest level of organizational performance compared to redistributive agency (3.595) and regulatory agency (3.564).

The United States. Regarding the effect of social capital and organizational performance, the results show that social capital has a positive influence on organizational performance. Hypothesis 1 is strongly supported; adjusted $\mathrm{R}^{2}$ of efficiency is .393 , adjusted $\mathrm{R}^{2}$ of effectiveness is .470 , adjusted $\mathrm{R}^{2}$ of responsiveness is .451, adjusted $\mathrm{R}^{2}$ of equity is .481 , and adjusted $\mathrm{R}^{2}$ of total dependent variables is .657 . In more detail, in Hypothesis 1-1, an organization with higher level of structural social capital was hypothesized to achieve higher levels of organizational performance. The data partially support Hypothesis 1-1, showing that structural social capital positively influences efficiency $(\beta=.372, \mathrm{p}<.0001)$ and equity $(\beta=.282, \mathrm{p}<.01)$. Although the coefficient for effectiveness and responsiveness are not statistically significant, the 
coefficient for effectiveness $(\beta=.113)$ and responsiveness $(\beta=.169)$ have a positive sign for structural social capital. However, structural social capital has a positive influence on total dependent variables or organizational performance $(\beta=.234, p<.001)$.

In Hypothesis 1-2, an organization with higher levels of relational social capital was hypothesized to have higher levels of organizational performance. The data support Hypothesis 1-2, showing that relational social capital has a positive influence on effectiveness $(\beta=.314, \mathrm{p}<.01)$, responsiveness $(\beta=.209, \mathrm{p}<.01)$, and equity $(\beta=.610$, $\mathrm{p}<.0001)$. Only the coefficient for efficiency (.037) is not significant, but it has a positive sign for relational social capital. Relational social capital has a positive influence on total dependent variables $(\beta=.292, \mathrm{p}<.001)$. In Hypothesis $1-3$, an organization with higher levels of cognitive social capital was hypothesized to achieve higher levels of organizational performance. The data support Hypothesis 1-3. Cognitive social capital is positively related to efficiency $(\beta=.192, \mathrm{p}<.01)$, effectiveness $(\beta=.344, \mathrm{p}<.001)$, responsiveness $(\beta=.369, \mathrm{p}<.0001)$, and total dependent variables $(\beta=.259, \mathrm{p}<.0001)$. However, the coefficient for equity is not significant.

In Hypothesis 2, the effect of social capital in a public sector organization on organizational performance was hypothesized to differ according to level of culture. Moderator regression analysis shows that the data do not support Hypothesis 2. The results show that the effect of social capital on organizational performance and the effect of culture on organizational performance is significant $(\mathrm{p}<.01)$. However, there is no moderating effect on the process of the effect of social capital on organizational performance, indicating that the significant $F$ change of culture is $p=.324$. 
In Hypothesis 3, culture, social capital, and organizational performance in public sector organizations were hypothesized to differ according to agency type. The data partially support Hypothesis 3 . The results show that most factors are not statistically significant $(\mathrm{p}<.01)$, except regulatory agency in the culture model and regulatory agency in the organizational performance model. For the culture model, redistributive agency has an influence as 2.956. For the social capital model, redistributive agency (3.611) has the highest levels of social capital, followed by distributive agency (3.590) and regulatory agency (3.359). In terms of organizational performance, distributive agency (3.548) has the higher level of organizational performance compared to redistributive agency (3.535) and regulatory agency (3.323).

Overall. When integrated with Korean data and the United States data, the results are as follows. With respect to Hofstede's framework, the results show that these countries contrasted on cultural characteristics. In other words, there are differences between the two countries, which means that Hofstede's results remain relevant. The United States has a lower power distance, low uncertainty avoidance, a short-term orientation, and higher career success (masculine) compared to South Korea. However, only the mean differences for collectivism/individualism are not significant—although the city of Omaha (3.19) is more likely to be individualist compared to Wonju city (3.14), which is the same as Hofstede's results.

For social capital, the mean differences between the two cities are not significant, except for cognitive social capital $(\mathrm{p}<.01)$. Wonju city $(3.74)$ has a higher level of cognitive social capital than the city of Omaha (3.60). Although it is not statistically 
significant, the city of Omaha has a slightly higher level of structural social capital and relational social capital compared to Wonju city, while Wonju city has a slightly higher level of cognitive social capital. As a whole, the level of social capital of Wonju city (3.53) is slightly higher than the city of Omaha (3.49). Regarding organizational performance, the mean differences between the two cities is statistically significant, except for responsiveness. Wonju city in efficiency, effectiveness, equity, and total organizational performance is higher than the city of Omaha. In sum, the differences between the two countries is represented in culture and organizational performance.

For the relationship between social capital and organizational performance, the results suggest that social capital positively influences organizational performance. Hypothesis 1 is strongly supported; adjusted $\mathrm{R}^{2}$ of efficiency is .431 , adjusted $\mathrm{R}^{2}$ of effectiveness is .481 , adjusted $\mathrm{R}^{2}$ of responsiveness is .365 , adjusted $\mathrm{R}^{2}$ of equity is .552 , and adjusted $\mathrm{R}^{2}$ of total dependent variables is .650. In more detail, in Hypothesis 1-1, an organization with higher level of structural social capital was hypothesized to achieve higher levels of organizational performance. The data support Hypothesis 1-1, showing that structural social capital positively influences efficiency $(\beta=.262, \mathrm{p}<.001)$, effectiveness $(\beta=.118, \mathrm{p}<.01)$, and equity $(\beta=.208, \mathrm{p}<.001)$. Although the coefficient for responsiveness is not statistically significant, the coefficient for responsiveness ( $\beta$ $=.086)$ has a positive sign for structural social capital. Structural social capital has a positive influence on total dependent variables or organizational performance $(\beta=.203, p$ $<.001)$. 
In Hypothesis 1-2, an organization with higher level of relational social capital was hypothesized to achieve higher levels of organizational performance. The data support Hypothesis 1-2, showing that relational social capital has a positive influence on effectiveness $(\beta=.181, \mathrm{p}<.001)$, responsiveness $(\beta=.240, \mathrm{p}<.001)$, and equity $(\beta$ $=.314, \mathrm{p}<.001)$. Only the coefficient for efficiency $(.018)$ is not significant, but it has a positive sign for relational social capital. Relational social capital has a positive influence on total dependent variables $(\beta=.231, \mathrm{p}<.001)$. In Hypothesis $1-3$, an organization with higher levels of cognitive social capital was hypothesized to achieve higher levels of organizational performance. The data strongly support Hypothesis 1-3. Cognitive social capital is highly, positively related to efficiency $(\beta=.461, \mathrm{p}<.001)$, effectiveness ( $\beta$ $=.468, \mathrm{p}<.001)$, responsiveness $(\beta=.350, \mathrm{p}<.001)$, and equity $(\beta=.313, \mathrm{p}<.001)$. Cognitive social capital has a positive influence on total dependent variables $(\beta=.465, \mathrm{p}$ $<.001)$.

In Hypothesis 2, the effect of social capital of public service organization on organizational performance was hypothesized to differ according to level of culture. Moderator regression analysis shows that the data do not support Hypothesis 2. The results show that the effect of social capital on organizational performance and the effect of culture on organizational performance are significant $(\mathrm{p}<.001)$. However, there is no moderating effect on the process of the effect of social capital on organizational performance, indicating that the significant $\mathrm{F}$ change of culture is $\mathrm{p}=.598$.

In Hypothesis 3, culture, social capital, and organizational performance in a public sector organization were hypothesized to differ according to agency type. The data 
support Hypothesis 3. The results show that all factors are statistically significant (p $<.01)$ in all models. For the culture model, distributive agency, redistributive agency, and regulatory agency have an influence as 3.223, 3.043, and 3.093, respectively. For social capital model, distributive agency (3.690) has the highest level of social capital, followed by redistributive agency (3.502) and regulatory agency (3.352). In terms of organizational performance, like social capital, distributive agency (3.776) has the highest level of organizational performance compared to redistributive agency (3.575) and regulatory agency (3.455).

In summary, the data support Hypothesis 1 for all groups: South Korea, the United States, and combined (Table 63). Yet, there is not enough evidence to support Hypothesis 2 for these groups. The results are mixed in terms of Hypothesis 3: the data from South Korea and the combined data provide support for the hypothesized effect. While data from the United States only partially support Hypothesis 3. Besides, this study finds out the nature of what an organization doses drives social capital rather than the other way around.

Table 63: Hypothesis Test Results

\begin{tabular}{|c|c|c|c|}
\hline & South Korea & The United States & Overall \\
\hline Hypothesis 1 & Supported & Supported & Supported \\
\hline Hypothesis 2 & Not supported & Not supported & Not supported \\
\hline Hypothesis 3 & Supported & Partially supported & Supported \\
\hline
\end{tabular}


Table 64 presents influential factors' ranking by groups for Hypothesis 1 . As the results of the effect of social capital on organizational performance show, the influential factors on efficiency are cognitive social capital and structural capital in all groups. For effectiveness and responsiveness, the most influential factor is cognitive social capital, followed by relational social capital in all groups. In terms of equity, cognitive social capital is the most influential factor in South Korea, while relational social capital is the most influential factor in the United States and overall data. In the case of South Korea, cognitive social capital is the most influential factor in all dependent variables, while in the United States structural social capital is the most influential factor on efficiency and relational social capital is the most influential factor on equity. Overall, cognitive social capital is the most influential factor on organizational performance, followed by relational social capital and structural social capital.

Table 64: Influential Factors' Ranking by Groups

\begin{tabular}{|c|c|c|c|c|}
\hline & & South Korea & $\begin{array}{c}\text { The United } \\
\text { States }\end{array}$ & Overall \\
\hline \multirow{5}{*}{ 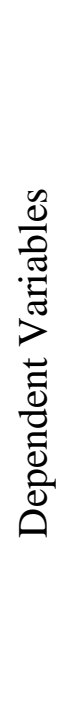 } & Efficiency & $\begin{array}{l}\text { Cognitive SC (1) } \\
\text { Structural SC (2) }\end{array}$ & $\begin{array}{l}\text { Structural SC (1) } \\
\text { Cognitive SC (2) }\end{array}$ & $\begin{array}{l}\text { Cognitive SC (1) } \\
\text { Structural SC (2) }\end{array}$ \\
\hline & Effectiveness & $\begin{array}{l}\text { Cognitive SC (1) } \\
\text { Relational SC (2) }\end{array}$ & $\begin{array}{l}\text { Cognitive SC (1) } \\
\text { Relational SC (2) }\end{array}$ & $\begin{array}{l}\text { Cognitive SC (1) } \\
\text { Relational SC (2) } \\
\text { Structural SC (3) }\end{array}$ \\
\hline & Responsiveness & $\begin{array}{l}\text { Cognitive SC (1) } \\
\text { Relational SC (2) }\end{array}$ & $\begin{array}{l}\text { Cognitive SC (1) } \\
\text { Relational SC (2) }\end{array}$ & $\begin{array}{l}\text { Cognitive SC (1) } \\
\text { Relational SC (2) }\end{array}$ \\
\hline & Equity & $\begin{array}{l}\text { Cognitive SC (1) } \\
\text { Relational SC (2) } \\
\text { Structural SC (3) }\end{array}$ & $\begin{array}{l}\text { Relational SC (1) } \\
\text { Structural SC (2) }\end{array}$ & $\begin{array}{l}\text { Relational SC (1) } \\
\text { Cognitive SC (2) } \\
\text { Structural SC (3) }\end{array}$ \\
\hline & Total DV & $\begin{array}{l}\text { Cognitive SC (1) } \\
\text { Relational SC (2) } \\
\text { Structural SC (3) }\end{array}$ & $\begin{array}{l}\text { Relational SC (1) } \\
\text { Cognitive SC (2) } \\
\text { Structural SC (3) }\end{array}$ & $\begin{array}{l}\text { Cognitive SC (1) } \\
\text { Relational SC (2) } \\
\text { Structural SC (3) }\end{array}$ \\
\hline
\end{tabular}

*The numbers in parenthesis are influence ranking. 


\section{CHAPTER 5: CONCLUSION}

\section{Summary of the Study}

Over the past few decades, social capital has garnered a great deal of political and academic attention. Interest in the performance of government organizations has significantly increased. In the United States, the performance evaluation of government organizations has been increasing for over 20 years (Sean et al., 2006). In Korea, a performance-oriented atmosphere is widely cultivated in government organizations (Kim \& Ahn, 2007). The present study is motivated by the proposition that the performance of governmental organizations should be improved according to the effect of new public management because new public management emphasizes the concept that ideas used in the private sector must be successful in the public sector.

The present study reveals alternatives for improving governmental performance via social capital. This study has examined, in particular, the way in which social capital influences organizational performance, how this may vary among national cultures, and whether cultures, social capital, and organizational performance may differ according to agency type. To examine the effect of social capital on organizational performance in different cultures, this study used social capital as an independent variable, which consists of structural social capital, relational social capital, and cognitive social capital; organizational performance as a dependent variable, which includes efficiency, effectiveness, responsiveness, and equity; and culture as a moderator variable. For agency type, this study utilized Lowi's policy typology: regulatory agencies, distributive 
agencies, and redistributive agencies. In line with the purpose of this study, the United States and South Korea were chosen as comparative countries based on Hofstede's work on national cultures. The city of Omaha and Wonju city were chosen as typical representatives of each country, which were selected to be as close as possible to the national averages on different criteria. A self-administered survey questionnaire was sent to public servants in two cities: the city of Omaha with 111 surveys, and Wonju city with 183 surveys.

The major findings of this study, based on analysis results, are as follows. Regarding hypotheses, the results support Hypothesis 1 in all groups: South Korea, the United States, and combined. In other words, organizational level social capital in a public sector organization has a positive influence on organizational performance. However, the data did not support Hypothesis 2 for all groups. Culture did not influence the process by which social capital influences organizational performance in a public sector organization. The data from South Korea and the combined data supported Hypothesis 3, while data from the United Sates partially supported Hypothesis 3. Culture, social capital, and organizational performance in a public sector organization varied by agency type.

For Hypothesis 1, cognitive social capital is the most influential factor on organizational performance in most parts of all groups. In South Korea, cognitive social capital is the most influential factor on all organizational performance, followed by relational social capital and structural social capital. On the other hand, in the United States, structural social capital is the most influential factor on efficiency and relational 
social capital is the most influential factor on equity and total dependent variableorganizational performance. In South Korea, the most influential factor on organizational performance is cognitive social capital such as shared missions, values, and objectives. When the local government's missions, values, and objectives are clearly and widely known and understood, organizational performance improves. In the United States, the most influential factor on organizational performance is relational social capital. If there is a high level of interpersonal trust and institutional trust, organizational performance increases. Overall, cognitive social capital is the most influential factor on organizational performance, except on equity. Relational social capital is the most influential factor on equity in the United States and combined. However, in South Korea, cognitive social capital is the most influential factor on equity. Relational social capital, such as interpersonal trust and institutional trust, is an important factor to improve equity in the United States, whereas clearly understood organizational missions and objectives are more important to enhance equity in South Korea.

\section{Policy Implications}

This study has developed a more comprehensive theoretical framework for defining social capital and organizational performance than previously developed in past research. Social capital is a critical domain in public management because it is central to performance improvement. In particular, this is the first study to analyze how culture has influenced the relationship between social capital and organizational performance. In addition, this study examines whether culture, social capital, and organizational 
performance differ according to agency type, which has not been done in the public sector. This study attempts to fill this gap in the literature by providing empirical evidence on how social capital influences organizational performance in government organizations. Thus, this study advances the empirical understanding of social capital and organizational performance by comparing the local governments in the two countries.

Because improving performance is a main objective of every government agency, it is important to understand how social capital influences organizational performance in order to enhance performance. By integrating public organizational theories with social capital literature, this study suggests the determinants of public sector performance. According to the results of the analysis, this study has several practical implications for government managers and leaders providing some practical guidelines to government leaders on how to increase social capital to enhance organizational performance. The findings provide clues that government leaders may consider for facilitating social capital. Based on the results of the analysis, the policy implications to increase social capital and improve organizational performance as a whole are detailed below.

First, the strongest factor that influences organizational performance is cognitive social capital. Cognitive social capital includes the broader organizational mission, values, and objectives. Such values and goals enable organization members to have the same understanding, which in turn contributes to the problem-solving ability of organizations. Therefore, clearly and widely understood organizational missions, values, and goals are important to improving organizational performance. Of the five factors of cognitive social capital, three of them are high in terms of levels of social capital: (1) 
understanding missions, values, and objectives, (2) value of missions and objectives, and (3) achievement of objectives. However, the two remaining factors are low in relation to levels of social capital: (4) the consistency of objectives and (5) no conflict with the objectives. That is, the consistency of objectives and conflict with the objectives in civil service decrease cognitive social capital. Thus, alternatives to sustain the consistency of objectives and resolve conflict with the objectives should be proposed to improve cognitive social capital.

Second, the study results show that relational social capital is the second-most influential factor. Relational social capital was deeply related to trust as the key element of social capital, and includes interpersonal trust and institutional trust. Many scholars who write about social capital have emphasized the importance of social trust (Coleman, 1988; Fukuyama, 1995; Leanna \& Van Buren, 1999; Putnam, 1993). Accordingly, government managers should establish trust to promote higher levels of organizational performance. Of the factors for relational social capital, the levels of trust among coworkers, trust between top-management and staff, and trust among other departments are relatively high in terms of levels of social capital. However, the levels of trust in local elected officials/council members, trust in local council, and trust in public servants' labor union are low. In particular, the level of trust in local elected officials/council members is the lowest. Thus, government leaders should seek strategies to establish trust, as these factors decrease relational social capital, which in turn decreases organizational performance. Also, government managers need to activate informal gatherings and diversify welfare benefaction for organization members. This will instill a sense of duty 
and devotion to their organization as well as increase mutual trust. Furthermore, government agencies should maintain consistency, fairness, and transparency for building institutional trust, enhance the morality of power elites and high ranking officials who manage government agencies, and control their corruption.

Finally, structural social capital also influences organizational performance. Although its influence is relatively low compared to other factors, structural social capital has a high influence on the efficiency of the factor for organizational performance. Structural social capital refers to the presence or absence of a network of access to people and resources, and includes internal co-ordination, external co-ordination, internal connectivity, and external connectivity. Such linkages and connections among persons bring efficiency in performing duties, and influence the speed of organizational learning. As Willem and Scarborough (2006) argued, when interaction between different departments is encouraged, individuals can access information and knowledge and accomplish collective goals. Accordingly, such coordination and connectivity are important factors to promote performance. Of the four factors of structural social capital, results from the present study show that internal connectivity is high, whereas external connectivity is relatively low in relation to levels of social capital. In other words, they have various networks and share information with other departments, but are not strongly linked by community organizations. Thus, government leaders should seek ways to communicate with community organizations. For active information sharing and cooperation, task force and workshops are required, and informal gatherings for organization members are needed to stimulate. 
Based on the results of influential factors' ranking, the policy implications to improve organizational performance for each country are as follows. For South Korea, cognitive social capital is the most influential factor on organizational performance. Of the four factors of cognitive social capital, no conflict with objectives (3.28) is low compared to other factors. Conflict with organizational objectives in a local government organization decreases organizational performance. Thus, government leaders should resolve the conflict and sustain consistent objectives to improve organizational performance. Relational social capital is the second-most influential factor on organizational performance. Of the factors of relational social capital, levels of trust in local council (2.88), trust in local elected officials/council members (2.91), and trust in public servants labor union (2.99) are low compared to other factors. Government leaders should increase the level of trust in them through vigorous interchanges such as workshops and informal gatherings. Furthermore, government managers should improve transparency by establishing a culture of trust. Structural social capital is the third-most influential factor on organizational performance. In particular, structural social capital is the second-most factor on efficiency. Thus, co-ordination and connectivity with members, other departments, and community organizations should be strengthened for organizational performance.

For the United States, relational social capital is the most influential factor on organizational performance, in particular, on equity. Of the factor of relational social capital, trust in local elected officials/council members (2.99) is the lowest, while the remaining other factors are over 3.3. Trust as the key element of social capital is closely 
linked to shared objectives and shared values and plays an important role in the exchange and sharing of knowledge and information. As many scholars have emphasized the importance of trust, government leaders should have an interest in promoting trust. In particular, government leaders should increase the level of trust in local elected officials/council members as that is the lowest factor. Cognitive social capital is the second-most influential factor on organizational performance, and the most influential factor on effectiveness and responsiveness. That is, clearly understood organizational shared missions, values, and objectives of the local government organization are important factors to attain planned goals, to improve the quality of business process and business productivity, and to respond to demands of citizens. Structural social capital is the third-most influential factor on organizational performance, the second-most influential factor on equity, and the primary influential factor on efficiency. The presence of a network of access to people and resources enables persons within an organization access to relevant peers with desired sets of knowledge. Such internal, external cooperation, and connectivity are important to reduce time in handing their tasks and costs related to dealing with tasks, and to improve accuracy of the business process and administrative efficiency. Also, the factors of structural social capital influence fairness. Thus, government leaders should enhance the level of structural social capital. Of the four factors of structural social capital, external connectivity (3.28) is relatively lower than other factors. Government leaders should propose strategies to enable their organizations to be strongly linked to community organizations. 
Social capital studies have argued that social capital influences organizational performance. Knowledge of this impact provides important information and can potentially encourage other cities to adopt such measures. This study provides some evidence on the facilitating factors influencing organizational performance. The findings provide both practitioners and scholars with a better understanding of the relationships between social capital and organizational performance in two different cultural contexts. This study's primary theoretical contribution to the field of public administration is that it competitively examines the impact of social capital on performance in two different cultural contexts.

\section{Limitations and Future Study}

This study has limitations that should be considered and perhaps overcome in future studies. First, this study employed survey data, which was only collected in the city of Omaha in the United States and Wonju city in South Korea. That is, this study focused only on two cites. Although these cities were selected as typical representatives for each country, the problem of representativeness may be raised. For example, because these cities are relatively small, the findings might be completely different in larger metropolitan areas or even in smaller rural areas in terms of the magnitude and directions of relationships. Thus, future studies need to expand the analysis to other cities to determine the generalizability of the results. 
Second, this study relied on quantitative research methods. Such methods can miss in-depth aspects of social capital and organizational performance that can be measured by interpretative approaches and qualitative methodologies. Studies using qualitative methodologies are essential in making causal inferences because of the ambiguous findings often obtained in quantitative studies (King, Keohane, \& Verba, 1994). Future research needs to consider case studies through qualitative methodologies to better explain quantitative findings.

Third, this study measured social capital and organizational performance based on the respondents' subjective perceptions — as most previous studies did. Accordingly, there might be measurement errors, which can influence the relationship between social capital and organizational performance. Future studies will need to overcome the limitation of data collection and develop measurement methods that are more objective. Also, further studies in this field must be conducted on a wider basis so that a detailed development of indicators can be achieved in future research.

Lastly, future studies might consider the following issue. The result of analysis for Hypothesis 3 suggests that the possibility that the nature of an organization, in terms of the policy activity in which it engages, may drive the development of social capital. Therefore, future studies need to examine the extent to which agency type impacts social capital through qualitative research. 


\section{REFERENCES}

Adams. J. S. (1963). Towards an Understanding of Inequality. Journal of Abnormal and Normal Social Psychology. 67 (5): 422-436.

Adams. J. S. (1965). "Inequality in Social Exchange" in Advances in Experimental Psychology. L. Berkowitz (ed). Academic Press, New York.

Adler, P. S., \& Kwon, S. W. (2000). Knowledge and Social Capital: Foundations and Applications. Boston: Burtworth Heinemann.

Adler, P. S., \& Kwon, S. W. (2002). Social Capital: Prospects for a New Concept. The Academy of Management Review. 27(1).

Atkinson, S. \& Butcher, D. (2003). Trust in the Context of Management Relationships: An Empirical Study. Advanced Management Journal. 68(4): 24-35.

Altman, E. I. (1993). Corporate Financial Distress and Bankruptcy. John Wiley and Sons: New York.

Ammons, D. N. (1995). Overcoming the Inadequacies of Performance Measurement in Local Government. N. Y.: Sage Publications.

Andrew, R. (2010). Organizational Social Capital, Structure and Performance. Human Relations. 63(5): 583-608.

Arrow, K. J. (2000). Observations on Social Capital. In Social Capital. A Multifaceted Perspective. Edited by P. Dasgupta and I. Serageldin. Washington D.C.: The World Bank.

Babbie, E. (2001). The Practice of Social Research ( $9^{\text {th }}$ ed.). Belmont, CA.: Wadsworth.

Bae, K. H. (2005). The Process of Enhancing Social Capital in the City of Los Angeles. International Review of Public Administration. 9(2).

Ball, Rob. (1998). Performance Review in Local Government. Vermont: Ashgate Publishing Company. 
Bandiera, O., Barankay, I. \& Rasul, I. (2008). Social Capital in the Workplace: Evidence on its Formation and Consequences. Labour Economics. 15(4):725-749.

Barnard, C. (1938). The Functions of the Executive. Harvard University Press. Cambridge.

Becker, G. (1964). Human Capital. Chicago: University of Chicago Press.

Behn, R. D. (1995). The Big Questions of Public Management. Public Administration Review. 55 (4).

Behn, R. D. (2003). Why Measure Performance? Different Purposes Require Different Measures. Public Administration Review. 63(5).

Bies, R. J., \& Moag, J. F. (1986). Interactional justice: Communication criteria of fairness. Research on Negotiations in Organizations. 1: 43-55.

Boix, C., \& Posner, D. N. (1998). Social Capital: Explaining Its Origins and Effects on Government Performance. British Journal of Political Science. 28(4).

Boland, R. J., \& Tenkasi, R. V. (1995). Perspective Making and Perspective Taking in Communities of Knowing. Organization Science. 6.

Bolino, M. C., Turnley, W. H., \& Bloodgood, J. M. (2002). Citizenship Behavior and the Creation of Social Capital in Organizations. Academy of Management Review. 27(4): 505-552.

Booth, J. A., \& Richard, P. B. (1998). Civil Society, Political Capital, and Democratization in Central America. Journal of Politics. 60: 780-800.

Bourdieu, P. (1986). The Forms of Capital in J. G. Richardson (ed). Handbook of Theory and Research for the Sociology of Education. New York: Greenwood.

Brewer, G. A. (2003). Building Social Capital: Civic Attitudes and Behavior of Public Servants. Journal of Public Administration Research and Theory. 13(1): 5-26.

Brudney, J. L., \& England, R. E. (1982). Urban Policy Making and Subjective Service Evaluations: Are They Compatible? Public Administration Review, 42, 127-135. 
Bryer, T. A. (2006). Stakeholder Approach to Bureaucratic Responsiveness: A Networkbased Framework to Analyze Public Administrator Value Preferences. International Journal of Organization Theory and Behavior. 9(4): 557-577.

Burt, R. S. (1997). The Contingent Value of Social Capital. Administrative Science Quarterly. 42(2).

Butt, H., \& Palmer, P. (1985). Value for Money in the Public Sector - the Decision makers Guide. Basil Blackwell: Oxford.

Coleman, J. S. (1988). "Social Capital in The Creation of Human Capital". American Journal of Sociology. 94.

Chanddhoke, N. (1995). State and Civil Society: Exploration of Political Theory. New Delhi: Sage Publications.

Chen, Z., Zhong, J. A., \& Lam, W. (2007). Leader-Member Exchange and Member Performance: A New Look at Individual-Level Negative Feedback-Seeking Behavior and Team-Level Empowerment Climate. Journal of Applied Psychology. 92. 202-212.

Chiu, C.M., Hsu, M.H. \& Wang, E.T.G. (2006). Understanding knowledge sharing in virtual communities: an integration of social capital and social cognitive theories. Decision Support Systems. 42(3): 1872-1888.

Cicourel, A. V. (1973). Cognitive Sociology. Harmondsworth. England: Penguin Books.

Cunningham, J. B. \& MacGregor, J. (2000). Trust and the Design of Work: Complementary Constructs in Satisfaction and Performance. Human Relations. 53(12): 1575-1591.

Cusack, T. R. (1999). Social Capital, Institutional Structures, and Democratic Performance: A Comparative Study of German Local Governments. European Journal of Political Research 35: 1-34.

du Toit, A. (2003). Knowledge: a Sense Making Process Shared through Narrative. Journal of Knowledge Management. 7(3): 27-37. 
Edwards, B., \& Foley, M. W. (1998). Civil Society and Social Capital beyond Putnam. The American Behavioral Scientist. 25(2).

Epstein, P. D. (1992). Measuring the Performance of Public Services. Public Productivity Handbook, New York: Marcel Dekker.

Epstein, P. D. (1992). Get Ready: The Time for Performance Measurement is Finally Coming. Public Administration Review, 52(5).

Evans, P. (1996). Government Action, Social Capital and Development. World Development. 24(6).

Fernandez, D. R., Carlson, D. S., Stepina, L. P., \& Nicholson, J. D. (1997). Hofstede's Country Classification 25 Years Later. The Journal of Social Psychology. 137(1): 43-54.

Fine, B. (2001). Social Capital versus Social Theory. Landon and New York: Routledge.

Foa, E. B., \& Foa, U. G. (2012). Resource Theory of Social Exchange. In K. Tornblom and A. Kazemi (eds). Handbook of Social Resource Theory: Theoretical Extensions, Empirical Insights, and Social Applications. Critical Issues in Social Justice. Springer Science Business Media New York.

Fried, R. C., \& Rabinovitz, F. F. (1982). Comparative Urban Politics: A Performance Approach. Journal of Public Policy. 2(1): 93-95.

Fukuyama, F. (1995). Trust: The Social Virtues and the Creation of Prosperity. New York: Free Press.

Ganapati, N. E. (2009). Rising from the Rubble: Emergence of Place-Based Social Capital in Golcuk, Turkey. International Journal of Mass Emergencies and Disasters. 27(2): 127-166.

Ganapati, N. E. (2013). Downsides of Social Capital for Women During Disaster Recovery: Toward a More Critical Approach. Administration \& Society. 
Glaser, M., \& Denhardt, R. (2000). Local government performance through the eyes of citizens Journal of Public Budgeting Accounting and Financial Management. 12(1): 49-73.

Goldfinger, J., \& Ferguson, M. R. (2009). Social Capital and Governmental Performance in Large American Cities. State and Local Government Review. 41(1): 25-36.

Gooderham, P. \& Nordhaug, O. (2001). Are Cultural Differences in Europe on the Decline? European Business Forum. 8 Winter 2001/2002: 48-53.

Goodstein, L. D. (1981). American Business Values and Cultural Imperialism. Organizational Dynamics. Summer: 49-54.

Graen, G. B., \& Uhl-Bien, M. (1995). Relationship-based approach to leadership: Development of the leader-member exchange (LMX) theory of leadership over 25 years. Leadership Quarterly, 6, 219-247.

Granovetter, M. S. (1973). The strength of weak ties. Collective lournal of Sociology. 78: 1360-1380.

Granovetter, M. S. (1974). Getting a job: A study of contacts and careers. Cambridge, MA: Harvard University Press.

Grootaert, C., \& Bastelaer, T. V. (2002). Understanding and Measuring Social Capital: A Multidisciplinary Tool for Practitioners. Washington, DC: The World Bank.

Grimmelikhuijsen, S., Porumbescu, G., Hong, B., \& Im, T. (2013). The Effect of Transparency on Trust in Government: A Cross-National Comparative Experiment. Public Administration Review. 73(4).

Hair, J. F., Anderson, R. E., Tatham, R. L., \& Black, W. C. (2006). Multivariate Data Analysis with Readings. New York: Macmillan Publishing.

Hanifan, L. J. (1916). The Rural School Community Center. Annals of the American Academy of Political and Social Science. 67.

Harris, J. (2003). Civil Society in British History: Ideas, Identities, Institutions. Oxford: Oxford University Press. 
Harrington, B. (2001). Organizational Performance and Corporate Social Capital: Contingency Model. Social Capital of Organizations. 18, pages 83-106.

Harpham, T., Grant, E., \& Thomas, E. (2002). Measuring Social Capital within Health Survey: Key Issues. Health Policy and Planning. 17(1): 106-111.

Hatcher, L. (1994). A Step by Step Approach to Using the SAS System for Factor Analysis and Structural Equation Modeling. Cary, NC: SAA Institute.

Hofstede, G. (2001). Culture's Consequences: Comparing Values, Behaviors, Institutions, and Organizations across Nations. $2^{\text {nd }}$ ed. Thousand Oaks. CA: Sage Publications.

Hofstede, G., Neuijen, B., Ohayv, D. D., \& Sanders, G. (1990). Measuring Organizational Cultures: A Qualitative and Quantitative Study across Twenty Cases. Administrative Science Quarterly. 35(2).

Hunt, J. W. (1981). Applying American Behavioral Science: Some Cross-Cultural Problems. Organizational Dynamics. Summer: 55-62.

Inglehart, R. (1997). Modernization and Postmodernization: Cultural, Economic and Political Change in 43 Societies. Princeton: Princeton University Press in 43 Societies. Princeton: Princeton University Press.

Innes, J., Gruber, J., Neuman, M., \& Thompson, R. (1994). Coordination Growth and Environmental Management through Consensus Building. Report to the California Policy Seminar. Berkeley: University of California.

Jung, C. S., \& Lee, S. Y. (2012). The Hawthorne Studies Revisited: Evidence from the U.S Federal Workforce. Administration \& Society. XX(X): 1-25.

Jreisat, J. E. (1997). Public Organization Management; The Development of Theory and Process. Westport: Greenwood Publishing Group Inc.

Kang, Y. B. (2003). Analysis of Community Identity and Social Capital Formulation Factors. Korean Policy Studies. 7(2). 
Kim, J. S., \& Jung, J. H. (2004). An Empirical Study on the Effect of Effectiveness of Human Resource Management on the Performance of Knowledge Management. Industry Economy Study. 17(3).

Kim, H. J. (1999). Trust and Organizational Commitment. Korean Public Administration Review. 33(2).

Kim, T. R. (2009). Critical Implication on the Relevance of Social Capital. Korean Governance Review. 16(4).

Kim, S. Y., \& Kim, G. D. (1996). A Study on the Model of Performance Evaluation of Public Services in Local Government. Local Government Research. 8(3).

Kim, T. R., \& Ahn, H. J. (2007). The Research Tendency of Performance Evaluation. Korean Association of Governmental Studies. 19(4): 1097-1118.

Kim, W. B., \& Lee, K. Y. (2000). Trust as Social Capital and Organizational Commitment Korean Sociological Association, 36(3).

King, G., Keohane, R. O., \& Verba, S. (1994). Designing Social Inquiry: Scientific Inference in Qualitative Research. Princeton University Press.

Krackhardt, D. (1992). The Strength of Strong Ties, In Nohria, N., \& Eccles, R.G. (eds), Networks and Organizations: Structure, Form and Action. Boston: Harvard Business School Press. Pp. 216-239.

Knack, S. (2002). Social Capital and the Quality of Government: Evidence from the States. American Journal of Political Science. 46: 772-85.

Knack, S., \& Keefer, P. (1997). Does Social Capital Have an Economic Payoff? A Crosscounty Investigation. The Quarterly Journal of Economics. 21(3).

Ko, K. H., \& Song, Y. Y. (2004). The Study about the Effect of Knowledge Sharing on Organizational Performance. Management Specialist Study. 7(2).

Kogut, B. \& Zander, U. (1996). What Do Firms Do? Coordination, Identity and Learning. Organization Science. 7(5): 502-518. 
Langbeing, L. \& Jorstad, C. (2004). Productivity in the Workplace: Cops, Culture, Communication, Cooperation, and Collusion. Political Research Quarterly. 57(1): 65-79.

Leana, C. R. \& Pil, K. P. (2006). Social Capital and Organizational Performance: Evidence from Urban Public Schools. Organization Science. 17(3): 353-366.

Lee, H. C., Park, H. B., \& Jeon, J. Y. (2007). The effect of Human Resource Management and Social Capital on the Organizational Performance of Local Government. KAPS. 11(3).

Lee, J. H. (1996). Trust, Transaction Cost, and network. Korean Sociological Association, 36.

Leventhal, G. S. (1980). What should be done with equity theory? New approaches to the study of fairness in social relationship. In K. J. Gergen, M. S. Greenberg, \& R. H. Willis (Eds.), Social exchange: Advances in theory and research (pp. 27-55). New York: Plenum.

Lijphart, A. (1971). Politics and the Comparative Method. American Political Science Review. 65(3): 375-407.

Lim, H. J., \& Kang, H. R. (2005). Learning Organization Study: Influence Factor of Mental Model and Team Effectiveness. Korean Society for Knowledge Management: Academic Symposium. $15^{\text {th }}$.

Lin, N. (2001). Social Capital: A Theory of Social Structure and Action. Cambridge, UK: Cambridge University Press.

Lin, N., Cook, K., \& Burt, R. (eds). (2001). Social Capital Theory and Research. New York: Aldine De Gruyter.

Lowi, T. J. (1964). American Business, Public Policy, Case-Studies, and Political Theory. World Politics. 32(4).

Lowi, T. J. (1972). Four Systems of Policy, Politics, and Choice. Public Administration Review. 32(4). 
Lowi, T. J. (1985). The State in Politics: The Relation Between Policy and Administration. In R. G. Noll, ed., Regulatory Policy and the Social Sciences. Berkeley, CA: University of California Press, pp. 67-105.

Lunenburg, F. C. (2010). Leader-Member Exchange Theory: Another Perspective on the Leadership Process. International Journal of Management, Business, and Administration. 13(1).

Luscher, S.L. and Lewis, M.W. (2008). Organizational Change and Managerial Sensemaking: Working through Paradox. Academy of Management Journal. 51(2): 221-240.

Mayer, R. C., Datis, J. H., \& Schoorman, F. D. (1995). An Integrative Model of Organizational Trust. Academy of Management Review. 20(3).

Miller, D. (1983). The Correlates of Entrepreneurship in Three Types of Firms. Management Science. 29(7): 770-791.

Miller, G. (1992). Managerial Dilemmas: The Political Economy of Hierarchy. New York: Cambridge University.

Min, J. (2003). Analysis of Concept Definition and Reconceptualization about Organizational Effectiveness. Korean Review of Public Administration. 37 (2): 83104.

Miner, J. B. (1980). Theories of organizational behavior. Hinsdale, Ill: Dryden.

Misztal, B. (1996). Trust in Modern Societies. Cambridge, England: Policy Press.

Morgan, D. I. (1988). Age Difference in Social Network Participation. Journal of Gerontology. 43.

Murphy, K. (1992). Performance Measurement and Appraisal: Motivating Managers to Identify and Reward Performance. in W. Bruns (ed.), Performance Measurement, Evaluation, and Incentives. Harvard Business School. 37-62. 
MSU SCIG. (1988). Social Capital Conference: Bridging Disciplines, Policies and Communities. Michigan State University.

Nahapiet, J., \& Ghoshal, S. (1998). Social Capital, Intellectual Capital, and Organizational Advantage. Academy of Management Review. 23(5).

Newman, M. A. (1993). Career Advancement: Does Gender Make a Difference? The American Review of Public Administration. 23(4): 361-384.

Newman, M. A. (1994). Lowi's Thesis and Gender: Implications for Career Advancement. Public Administration Review. 54(3): 277-284

Newton, K. (1999). Social and Political Trust in Established Democracies, In Pippa Noris (ed.), Critical Citizen: Global Support for Democratic Government. Oxford: Oxford University Press.

Ofori, D., \& Sackey, J. (2010). Assessing Social Capital for Organizational Performance: Initial Exploratory Insights from Ghana. Organizations and Markets in Emerging Economies. Vol. 1, No. 2(2).

Ostrom, E. (1975). On Evaluating the Effectiveness, Responsiveness, Equity, and Efficiency of Police Organizational Arrangements in Metropolitan Areas. Workshop in Political Theory and Policy Analysis. Indiana University.

Ostrom, E. (2000). Social Capital: A Multifaceted Perspective. Washington, DC: World Bank.

O’Sullivan, E., G. R. Rassel, \& M. Berner. (2003). Research Methods for Public Administrators ( $4^{\text {th }}$ ed.). Addison Westely Longman, Inc.

Park, C. M., \& Kim, D. W. (2003). The effect of Organizational Fairness on the Trust and Organizational Commitment. Korean Public Administration Review. 37(4).

Pennings, J. M., Lee, K. M., \& van Witteloostuijn, A. (1998). Human Capital, Social Capital, and Firm Dissolution. The Academy of Management Journal. 41(4).

Pierce, J. C., Lovrich Jr., N. P., \& Moon, C. D. (2002). Social Capital and Government Performance: An Analysis of 20 American Cites. Public Performance \& Management Review. 25(4). 
Platteau, J. P. (1996). Behind the Market Stage Where Real Societies Exist. Journal of Development Studies. 30.

Portes, A. (2000). The Meanings of Social Capital. Sociological Forum. 15(1).

Portes, A., \& Sensenbrenner, J. (1993). Embeddedness and Immigration: Notes on the Social Determinants of Economic Action. America Journal of Society. 98.

Putnam, R. D. (1993). The Prosperous Community: Social Capital and Public Life. The American Prospect. 13.

Putnam, R. D. (1993). Making Democracy Work: Civic Tradition Modern Italy. NJ: Princeton University Press.

Rainey, H. G. (1997). Understanding \& Managing Public Organization (2nd Edition). N. Y.: John Wiley \& Sons, Inc.

Rice, T. W. (2001). Social Capital and Government Performance in Iowa Communities. Journal of Urban Affairs. 23(3-4): 375-389.

Ripley, R., \& Franklin, G. (1987). Congress, the Bureaucracy, and Public Policy. Chicago, IL: The Dorsey Press.

Robins. S. P. (1990). Organization Theory: Structure, Design, and Applications. NJ.; Prentice Hall.

Roger, S. (1990). Performance Management in Local Government. London: Longman.

Rourke, F. E. (1992). Responsiveness and Neutral Competence in American Bureaucracy. Public Administration Review. 52(6): 539-546.

Russell, C., \& Mitchell, M. S. (2005). Social Exchange Theory: An Interdisciplinary Review. Journal of Management. 31 (6).

Saltzstein, G. H. (1992). Bureaucratic Responsiveness: Conceptual Issues and Current Research. Journal of Public Administration Research and Theory. 2(1): 63-88.

Scott, J. (1991). Social network analysis: A handbook. London: Sage. 
Scott, W. R. (2001). Institutions and Organizations, $2^{\text {nd }}$ ed. London: SAGE.

Schwartz, S. H. (1994). Are there universal aspects in the content and structure of values? Journal of Social Issues, 50, 19-45.

Selznick, P. (1957). Leadership and Administration: A Sociological Interpretation. Evanston, IL: Harper \& Pow.

Seo, J. H. (2011). A Study on the Change of Organization Units for Service Function of Local Government: Focusing on the Service Needs and the Change of Local Autonomy. The Korean Local Administration Review. 25(3): 125-154.

Singleton, R., Straits, B., Straits, M., \& McAllister, R. (2005). Approaches to Social Research. Oxford University Press: New York.

Skarlicki, D. P., \& Folger, R. (1997). Retaliation in the workplace: The roles of distributive, procedural, and interactional justice. Journal of Applied Psychology. 82: 434-443.

Song, S. H., \& Shim, J. S. (2005). The Effect of Knowledge Management Readiness on Organizational Performance and E-Biz Performance. Knowledge Study. 3(2).

Spector, P. (1992). Summated Rating Scale Construction: An Introduction: Sage Publications, Inc.

Stivers, C. (1994). The Listening Bureaucrat: Responsiveness in Public Administration. Public Administration Review. 54 (4): 364-369.

Subramaniam, N., Stewrt, J., Ng, C., \& Shulman, A. (2013). Understanding Corporate Governnance in the Australian Public Sector: A Social Capital Approach. Accounting Auditing \& Accountability Journal. 26(6): 946-977.

Szilagyi, A. D. Jr., \& Wallace, M. J. Jr. (1990). Organizational Behavior and Performance (5th). New York: Harper Collins Publishers. 
Tarrow, S. (1996). Making Social Science Work Across Space and Time: A Critical Reflection on Robert Putnam's Making Democracy Work. American Political Science Review. 90(2).

Thibaut, J., \& Walker, L. (1975). Procedural justice: A psychological analysis. Hillsdale, NJ: Erlbaum.

Tocqueville, A. (1984). Democracy in America. Renewed by Richard D. Heffner. New York: New American Library, A Division of Penguin Books.

Tsai, W. \& Ghoshal, S. (1998). Social Capital and Value Creation: The Role of Intra-firm Networks. Academy of Management Journal. 41(4): 464-478.

Uphoff, N. (2000). Understanding Social Capital: Learning from the Analysis and Experience of Participation in Social Capital: A Multifaceted Perspective. The World Bank: Washington, D.C.

Van Deth. J. W. (2008). Measuring Social Capital. In the Handbook of Social Capital. Oxford University Press.

Walker, G., Kogut, B., \& Shan, W. (1997). Social Capital, Structural Holes and the Formation of an Industry Network. Organization Science. 8(2).

Wasserman. S. \& Faust, K. (1994). Social network analysis: Methods and applications. Cambridge, England: Cambridge University Press.

Willem, A. \& Buelens, M. (2007). Knowledge Sharing in Public Sector Organization: The Effect of Organizational Characteristics on Interdepartmental Knowledge Sharing. Journal of Public Administration Research and Theory. 17(4): 581-606.

Willem, A. \& Scarborough, H. (2006). Social Capital and Political Bias in Knowledge Sharing: An Exploratory Study. Human Relations. 59(1): 1342-1370.

Williamson, J. (1990). What Washington means by Policy Reform. In Williamson, J. (Ed.). Latin American Adjustment: How Much Has Happened? Institute for International Economics, Washington, DC, pp. 7-20. 
Winter, I. (2000). Towards a Theorized Understanding of Family Life and Social Capital. Australian Institute of Family Studies. Working Paper 21.

World Bank. (1998). The Initiative on Defining, Monitoring and Measuring Social Capital. Social Capital Initiative Working Paper No. 1.

World Bank. (2000). Social Capital for Development. www.worldbank.org.

Woolcock. M. (1998) Social Capital and Economic Development: Toward a Theoretical Synthesis and Policy Framework. Theory and Society. 27(2): 151-208.

Woolcock, M., \& Narayan, D. (2000). Social Capital: Implications for Development Theory, Research, and Policy. The World Bank Research Observer. 15(2).

Wright, D. S., (1988). Understanding Intergovernmental Relations. Pacific Grove, CA: Brooks/Cole Publishing Co.

Yang, K., \& Pandey, S. K. (2007). Public Responsiveness of Government Organizations: Testing a Preliminary Model. Public Performance \& Management Review. 31 (2): 215-240.

Yoo, B. H., Donthu, N., \& Lenartowicz, T. (2011). Measuring Hofstede's Five Dimensions of Cultural Values at the Individual Level: Development and Validation of CVSCALE. Journal of International Consumer Marketing. 23: 193-210.

Yoon, J. M. (2000). Representativeness of Public Administration and Citizen Participation. Managing WWW in the Korean Association for Public Administration: Leadership of Local Government and Cultural Industry Policy. 


\section{APPENDIX 1}

Table 65: City Selection Criteria (The City of Omaha)

\begin{tabular}{|c|c|c|c|}
\hline \multirow{2}{*}{$\begin{array}{c}\text { Type of } \\
\text { Agencies }\end{array}$} & \multicolumn{3}{|c|}{ The City of Omaha } \\
\hline & Department & Mission statement & Selection criteria \\
\hline $\begin{array}{l}\text { Distributive } \\
\text { agency }\end{array}$ & Public Works & $\begin{array}{l}\text { To effectively meet the transportation and } \\
\text { environmental quality needs of the citizens. } \\
\text { Provides many of the basic services that affect the } \\
\text { daily livers of all who live and work in Omaha. } \\
\text { Responsibilities are the design, construction and } \\
\text { maintenance of the City's infrastructure including } \\
\text { sewers, parking, streets and traffic control, as well } \\
\text { as fleet management and waste water treatment. }\end{array}$ & $\begin{array}{l}\text { According to Lowi's policy } \\
\text { definition, distributive agency } \\
\text { includes most contemporary } \\
\text { public land and resource policies. } \\
\text { Previous study (e.g., Newman, } \\
\text { 1994) categorized transportation } \\
\text { and environmental needs as } \\
\text { distributive agency. }\end{array}$ \\
\hline \multirow[t]{2}{*}{$\begin{array}{l}\text { Redistributive } \\
\text { agency }\end{array}$} & $\begin{array}{l}\text { Human Rights and } \\
\text { Relations }\end{array}$ & $\begin{array}{l}\text { Civil rights enforcement, contract compliance and } \\
\text { community relations/discrimination prevention } \\
\text { The investigation, elimination, and prevention of } \\
\text { all forms of prohibited discrimination, including } \\
\text { that based on race, creed, color, religion, sex, } \\
\text { national origin, age, disability, marital status, } \\
\text { familial status, retaliation, sexual orientation, } \\
\text { gender identity or any other form of discrimination } \\
\text { proscribed by ordinance or resolution and one } \\
\text { appointed council: the Economic Inclusion } \\
\text { Council. }\end{array}$ & $\begin{array}{l}\text { The main purpose of department } \\
\text { is to provide greater opportunities } \\
\text { for disadvantage classes. }\end{array}$ \\
\hline & Human Resources & $\begin{array}{l}\text { Administer HR policies and procedures } \\
\text { Administrative city's equal employment } \\
\text { appointment opportunity program } \\
\text { Direct HR programs throughout the City of Omaha } \\
\text { Provide assistance to the Personnel Board }\end{array}$ & $\begin{array}{l}\text { Lowi's definition: in the long run, } \\
\text { all government policies may be } \\
\text { considered redistributive. The } \\
\text { same goes for our various welfare } \\
\text { state programs, which are } \\
\text { redistributive only for those who } \\
\text { entered retirement or } \\
\text { unemployment rolls without } \\
\text { having contributed at all. }\end{array}$ \\
\hline \multirow[t]{3}{*}{$\begin{array}{l}\text { Regulatory } \\
\text { agency }\end{array}$} & $\begin{array}{l}\text { Permits and } \\
\text { Inspections }\end{array}$ & $\begin{array}{l}\text { Code administration, Permitting, Inspections, } \\
\text { Occupational licensing through lawful enforcement } \\
\text { of the adopted construction codes and ordinances, } \\
\text { Administering and enforcing Omaha's building, } \\
\text { electrical, plumbing, mechanical, and sign codes. }\end{array}$ & $\begin{array}{l}\text { According to Lowi (1985), } \\
\text { formulating or implementing } \\
\text { rules imposing obligations on } \\
\text { individuals, and providing } \\
\text { punishment for nonconformance } \\
\text { is included in regulatory. }\end{array}$ \\
\hline & $\begin{array}{l}\text { Housing and } \\
\text { Community } \\
\text { Development }\end{array}$ & $\begin{array}{l}\text { Neighborhood revitalization } \\
\text { Enforce housing standards codes } \\
\text { Develop and rehabilitate public facilities } \\
\text { Focus on the development of commercial and } \\
\text { industrial properties } \\
\text { Housing counseling, underwriting, and funding for } \\
\text { several programs }\end{array}$ & $\begin{array}{l}\text { Formulating or implementing } \\
\text { rules imposing obligations on } \\
\text { individuals, and providing } \\
\text { punishment for nonconformance } \\
\text { is included in regulatory (Lowi, } \\
\text { 1985). }\end{array}$ \\
\hline & Urban Planning & $\begin{array}{l}\text { Current planning, Long range planning, and Urban } \\
\text { design }\end{array}$ & $\begin{array}{l}\text { Formulating or implementing } \\
\text { rules imposing obligations on } \\
\text { individuals, and providing } \\
\text { punishment for nonconformance } \\
\text { is included in regulatory (Lowi, } \\
\text { 1985). }\end{array}$ \\
\hline
\end{tabular}


Table 66: City Selection Criteria (Wonju City)

\begin{tabular}{|c|c|c|c|}
\hline \multirow{2}{*}{$\begin{array}{l}\text { Type of } \\
\text { Agencies }\end{array}$} & \multicolumn{3}{|c|}{ Wonju City } \\
\hline & Department & Mission statement & Selection criteria \\
\hline \multirow[t]{4}{*}{$\begin{array}{l}\text { Distributive } \\
\text { agency }\end{array}$} & $\begin{array}{l}\text { Health and } \\
\text { Physical } \\
\text { Education }\end{array}$ & $\begin{array}{l}\text { Support sport for all } \\
\text { Design, manages, expand, and maintain public sports } \\
\text { facilities and village sports facilities } \\
\text { Support the construction of sports park } \\
\text { Provide the basic services that affect the daily livers } \\
\text { of all }\end{array}$ & $\begin{array}{l}\text { According to Lowi's policy } \\
\text { definition, distributive agency } \\
\text { includes most contemporary public } \\
\text { land and resource policies. } \\
\text { Patronage is a synonym for } \\
\text { distributive. }\end{array}$ \\
\hline & Parks & $\begin{array}{l}\text { Manage parks (neighborhood parks, children parks) } \\
\text { Restore the flood area } \\
\text { Manages and repairs facilities of parks } \\
\text { Examines the safety facilities of children parks } \\
\text { Manage street trees }\end{array}$ & $\begin{array}{l}\text { Lowi includes public land and } \\
\text { resource polices as distributive. }\end{array}$ \\
\hline & $\begin{array}{l}\text { Information and } \\
\text { Communications }\end{array}$ & $\begin{array}{l}\text { Operate information network village and Wonju city } \\
\text { homepages } \\
\text { Operate comprehensive administration systems } \\
\text { Planning and adjustment of administration service } \\
\text { Settle civil complaints }\end{array}$ & $\begin{array}{l}\text { Lowi includes clientele services and } \\
\text { basic services that affect the daily } \\
\text { lives. }\end{array}$ \\
\hline & Forests & $\begin{array}{l}\text { Forest conservancy, Forest fire prevention, Forest } \\
\text { management, Preparation of resources, Afforestation, } \\
\text { Creation forest of usable (economical) trees complex, } \\
\text { Prevention of damage form storm and flood, Disaster } \\
\text { restoration }\end{array}$ & $\begin{array}{l}\text { Lowi includes public land and } \\
\text { resource polices as distributive. } \\
\text { Lowi includes basic services that } \\
\text { affect the daily lives. }\end{array}$ \\
\hline \multirow[t]{3}{*}{$\begin{array}{l}\text { Redistributive } \\
\text { agency }\end{array}$} & Welfare Policy & $\begin{array}{l}\text { Manage victim (suffers) and relief supplies } \\
\text { Local social welfare task } \\
\text { Manage, support, and operate social welfare council } \\
\text { and welfare councilor } \\
\text { Establish and evaluate local social welfare planning } \\
\text { Manage and support comprehensive social welfare } \\
\text { center } \\
\text { Childcare subsidies }\end{array}$ & $\begin{array}{l}\text { Lowi's definition: the aim involved } \\
\text { is property itself, equal possession, } \\
\text { not behavior but being. } \\
\text { Welfare state programs are included } \\
\text { in redistributive. } \\
\text { Previous study (e.g., Newman, } \\
\text { 1994) includes welfare as } \\
\text { redistributive. }\end{array}$ \\
\hline & $\begin{array}{l}\text { Livelihood } \\
\text { Security }\end{array}$ & $\begin{array}{l}\text { Support the recipients of basic livelihood security } \\
\text { Investigate and manage the recipients of welfare. }\end{array}$ & $\begin{array}{l}\text { Lowi's definition: welfare is } \\
\text { included in redistributive. }\end{array}$ \\
\hline & $\begin{array}{l}\text { Women and } \\
\text { Family }\end{array}$ & $\begin{array}{l}\text { Female welfare task, Support and manage women's } \\
\text { organization, Support family service agency and } \\
\text { women welfare facilities, Support one-parent family }\end{array}$ & $\begin{array}{l}\text { Lowi's definition: welfare is } \\
\text { included in redistributive. }\end{array}$ \\
\hline \multirow[t]{3}{*}{$\begin{array}{l}\text { Regulatory } \\
\text { agency }\end{array}$} & $\begin{array}{l}\text { Traffic } \\
\text { Administration }\end{array}$ & $\begin{array}{l}\text { Manage traffic safety deliberative committee } \\
\text { Permission and approval of traffic facilities and } \\
\text { architecture } \\
\text { Collection of fines and penalties } \\
\text { Delinquency management } \\
\text { Seize property and car } \\
\text { Manage payment system of penalty fee } \\
\text { Charge penalty } \\
\text { Regulation and control of illegal parking }\end{array}$ & $\begin{array}{l}\text { According to Lowi (1985), } \\
\text { formulating or implementing rules } \\
\text { imposing obligations on } \\
\text { individuals, and providing } \\
\text { punishment for nonconformance is } \\
\text { included in regulatory. }\end{array}$ \\
\hline & Architecture & $\begin{array}{l}\text { Permission of architecture, Regulation and control of } \\
\text { illegal building } \\
\text { Charge of compelling the } \\
\text { performance/compliance/execution }\end{array}$ & $\begin{array}{l}\text { Permission, regulation, and control } \\
\text { are included in regulatory (Lowi, } \\
\text { 1985; Newman, 1994). }\end{array}$ \\
\hline & $\begin{array}{l}\text { Construction } \\
\text { Accident } \\
\text { Prevention }\end{array}$ & $\begin{array}{l}\text { Design and supervise various construction } \\
\text { Approve various development work } \\
\text { Permission of the road business of unmanaged office } \\
\text { Operate the change of design council } \\
\text { Design and supervise disaster prevention business } \\
\text { and small business related to river }\end{array}$ & $\begin{array}{l}\text { Permission, approval, and } \\
\text { supervision are included in } \\
\text { regulatory (Lowi, 1985; Newman, } \\
\text { 1994). }\end{array}$ \\
\hline
\end{tabular}




\section{APPENDIX 2}

Table 67: Culture Dimensions

\begin{tabular}{|c|c|c|c|c|c|c|}
\hline & \multicolumn{5}{|c|}{ Hofstede's Culture Dimension } \\
\hline & & $\begin{array}{c}\text { Power } \\
\text { Distance }\end{array}$ & $\begin{array}{l}\text { Uncertainty } \\
\text { Avoidance }\end{array}$ & $\begin{array}{l}\text { Individualism/ } \\
\text { Collectivism }\end{array}$ & $\begin{array}{c}\text { Career } \\
\text { Success/Mascul } \\
\text { ine }\end{array}$ & $\begin{array}{c}\text { Future } \\
\text { Orientation }\end{array}$ \\
\hline \multirow{2}{*}{$\begin{array}{c}\text { Country-Level } \\
\text { Values } \\
\text { (Hofstede) }\end{array}$} & U.S. & 40 & 46 & 91 & 62 & 29 \\
\hline & Korea & 60 & 85 & 18 & 39 & 75 \\
\hline \multirow{2}{*}{$\begin{array}{c}\text { City-Level } \\
\text { Values } \\
\text { (Survey Data) }\end{array}$} & $\begin{array}{l}\text { Omaha, } \\
\text { U.S. }\end{array}$ & 40.76 & 77.73 & 63.95 & 42.70 & 72.44 \\
\hline & $\begin{array}{l}\text { Wonju, } \\
\text { Korea }\end{array}$ & 44.53 & 82.31 & 62.93 & 54.26 & 78.07 \\
\hline
\end{tabular}




\section{APPENDIX 3}

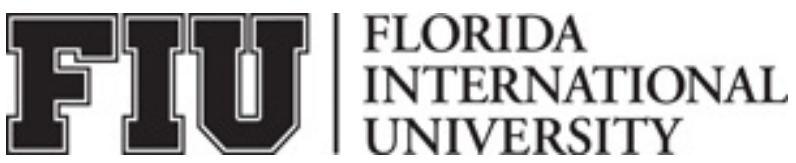

\section{Comparative Survey Questionnaire}

Thank you for taking the time to complete this survey.

The purpose of this study is to learn how social capital influences organizational performance in different cultures. The questionnaire that you are asked to complete will take about ten minutes.

Responses from all the questionnaires will be pooled together for a final report and no individual will be identified.

In the following pages, you are asked to respond to a number of statements that reflect your observations of organizational practices, your beliefs, your values, or your perceptions. This is not a test, and there are no right or wrong answers.

The questionnaire is anonymous. The results of the study may be published but your name will not be known. Information obtained during the course of the study will remain confidential, to the extent allowed by law.

If you have any questions concerning the research study, please feel free to contact the following references:

Meredith Newman, Professor

Jung Hyun Song, Ph.D. Candidate

Department of Public Administration

Florida International University

T: $\underline{541-207-5459}$

jsong003@fiu.edu 


\section{SECTION 1: Cultural Values}

Instruction: Each question is rated on a scale of 1 to 5, with 1 being strongly disagree and 5 being strongly agree. For each question please select the answer that best represents your response.

\begin{tabular}{|c|c|c|c|c|c|c|}
\hline \multirow[t]{2}{*}{ No. } & \multirow{2}{*}{ Question } & \multicolumn{5}{|c|}{ Scale } \\
\hline & & $\begin{array}{l}\text { strongly } \\
\text { disagree }\end{array}$ & disagree & Neutral & agree & $\begin{array}{l}\text { strongly } \\
\text { agree }\end{array}$ \\
\hline 1 & $\begin{array}{l}\text { People in higher positions should } \\
\text { make most decisions without } \\
\text { consulting people in lower positions. }\end{array}$ & (1) & (2) & (3) & (4) & (5) \\
\hline 2 & $\begin{array}{l}\text { People in higher positions should not } \\
\text { ask the opinions of people in lower } \\
\text { positions too frequently. }\end{array}$ & (1) & (2) & (3) & (4) & (5) \\
\hline 3 & $\begin{array}{l}\text { People in higher positions should } \\
\text { avoid social interaction with people } \\
\text { in lower positions. }\end{array}$ & (1) & (2) & (3) & (4) & (5) \\
\hline 4 & $\begin{array}{l}\text { People in lower positions should not } \\
\text { disagree with decisions by people in } \\
\text { higher positions. }\end{array}$ & (1) & (2) & (3) & (4) & (5) \\
\hline 5 & $\begin{array}{l}\text { People in higher positions should not } \\
\text { delegate important tasks to people in } \\
\text { lower positions. }\end{array}$ & (1) & (2) & (3) & (4) & (5) \\
\hline 6 & $\begin{array}{l}\text { It is important to have instructions } \\
\text { spelled out in detail so that I always } \\
\text { know what I'm expected to do. }\end{array}$ & (1) & (2) & (3) & (4) & (5) \\
\hline 7 & $\begin{array}{l}\text { It is important to closely follow } \\
\text { instructions and procedures. }\end{array}$ & (1) & (2) & (3) & (4) & (5) \\
\hline 8 & $\begin{array}{l}\text { Rules and regulations are important } \\
\text { because they inform me of what is } \\
\text { expected of me. }\end{array}$ & (1) & (2) & (3) & (4) & (5) \\
\hline 9 & $\begin{array}{l}\text { Standardized work procedures are } \\
\text { helpful. }\end{array}$ & (1) & (2) & (3) & (4) & (5) \\
\hline 10 & $\begin{array}{l}\text { Instructions for operations are } \\
\text { important. }\end{array}$ & (1) & (2) & (3) & (4) & (5) \\
\hline 11 & $\begin{array}{l}\text { Individuals should sacrifice self- } \\
\text { interest for the group. }\end{array}$ & (1) & (2) & (3) & (4) & (5) \\
\hline 12 & $\begin{array}{l}\text { Individuals should stick with the } \\
\text { group even though difficulties. }\end{array}$ & (1) & (2) & (3) & (4) & (5) \\
\hline 13 & $\begin{array}{l}\text { Group welfare is more important } \\
\text { than individual rewards. }\end{array}$ & (1) & (2) & (3) & (4) & (5) \\
\hline 14 & $\begin{array}{l}\text { Group success is more important } \\
\text { than individual success. }\end{array}$ & (1) & (2) & (3) & (4) & (5) \\
\hline 15 & $\begin{array}{l}\text { Individuals should only pursue their } \\
\text { goals after considering the welfare of } \\
\text { the group. }\end{array}$ & (1) & (2) & (3) & (4) & (5) \\
\hline
\end{tabular}




\begin{tabular}{|c|c|c|c|c|c|c|}
\hline 16 & $\begin{array}{l}\text { Group loyalty should be encouraged } \\
\text { even if individual goals suffer. }\end{array}$ & (1) & (2) & (3) & (4) & (5) \\
\hline 17 & $\begin{array}{l}\text { It is important to manage money } \\
\text { carefully for thrift. }\end{array}$ & (1) & (2) & (3) & (4) & (5) \\
\hline 18 & $\begin{array}{l}\text { Going on resolutely in spite of } \\
\text { opposition is necessary (persistence). }\end{array}$ & (1) & (2) & (3) & (4) & (5) \\
\hline 19 & $\begin{array}{l}\text { Personal steadiness and stability is } \\
\text { important. }\end{array}$ & (1) & (2) & (3) & (4) & (5) \\
\hline 20 & $\begin{array}{l}\text { Long-term planning is more } \\
\text { important than short-term planning. }\end{array}$ & (1) & (2) & (3) & (4) & (5) \\
\hline 21 & $\begin{array}{l}\text { Giving up today's fun for success in } \\
\text { the future is necessary. }\end{array}$ & (1) & (2) & (3) & (4) & (5) \\
\hline 22 & $\begin{array}{l}\text { It is important to work hard for } \\
\text { success in the future. }\end{array}$ & (1) & (2) & (3) & (4) & (5) \\
\hline 23 & $\begin{array}{l}\text { It is more important for men to have } \\
\text { a professional career than it is for } \\
\text { women. }\end{array}$ & (1) & (2) & (3) & (4) & (5) \\
\hline 24 & $\begin{array}{l}\text { Men usually solve problems with } \\
\text { logical analysis; women usually } \\
\text { solve problems with intuition. }\end{array}$ & (1) & (2) & (3) & (4) & (5) \\
\hline 25 & $\begin{array}{l}\text { Solving difficult problems usually } \\
\text { requires an active, forcible approach, } \\
\text { which is typical of men. }\end{array}$ & (1) & (2) & (3) & (4) & (5) \\
\hline 26 & $\begin{array}{l}\text { There are some jobs that a man can } \\
\text { always do better than woman. }\end{array}$ & (1) & (2) & (3) & (4) & (5) \\
\hline
\end{tabular}

\section{SECTION 2: Social Capital}

Instruction: Each question is rated on a scale of 1 to 5, with 1 being strongly disagree and 5 being strongly agree. For each question please select the answer that best represents your response.

\begin{tabular}{|c|l|c|c|c|c|c|}
\hline No. & \multicolumn{1}{|c|}{ Question } & \multicolumn{5}{|c|}{ Scale } \\
\cline { 3 - 7 } & $\begin{array}{l}\text { strongly } \\
\text { disagree }\end{array}$ & disagree & neutral & agree & $\begin{array}{l}\text { strongly } \\
\text { agree }\end{array}$ \\
\hline 1 & $\begin{array}{l}\text { Our department is actively working } \\
\text { together and coordinating with our } \\
\text { members. }\end{array}$ & $(1$ & $(2)$ & $(3$ & $(4)$ & (5) \\
\hline 2 & $\begin{array}{l}\text { Our department is coordinating and } \\
\text { joint working with other } \\
\text { departments. }\end{array}$ & $(1)$ & $(2)$ & $(3$ & $(4)$ & (5) \\
\hline 3 & $\begin{array}{l}\text { Our department has various } \\
\text { networks and shares information } \\
\text { with other departments. }\end{array}$ & (1) & $(2)$ & $(3$ & (4) & (5) \\
\hline
\end{tabular}




\begin{tabular}{|c|c|c|c|c|c|c|}
\hline 4 & $\begin{array}{l}\text { Our department is strongly linked by } \\
\text { community organizations. }\end{array}$ & (1) & (2) & (3) & (4) & (5) \\
\hline 5 & $\begin{array}{l}\text { Our department has a high level of } \\
\text { trust in a local government head. }\end{array}$ & (1) & (2) & (3) & (4) & (5) \\
\hline 6 & $\begin{array}{l}\text { There is a high level of trust between } \\
\text { top-management and staff in our } \\
\text { department. }\end{array}$ & (1) & (2) & (3) & (4) & (5) \\
\hline 7 & $\begin{array}{l}\text { There is a high level of trust among } \\
\text { co-workers in our department. }\end{array}$ & (1) & (2) & (3) & (4) & (5) \\
\hline 8 & $\begin{array}{l}\text { Our department has a high level of } \\
\text { trust in local assembly man. }\end{array}$ & (1) & (2) & (3) & (4) & (5) \\
\hline 9 & $\begin{array}{l}\text { Our department has a relationship of } \\
\text { trust with citizens. }\end{array}$ & (1) & (2) & (3) & (4) & (5) \\
\hline 10 & $\begin{array}{l}\text { Our department has a high level of } \\
\text { trust in public servants labor union. }\end{array}$ & (1) & (2) & (3) & (4) & (5) \\
\hline 11 & $\begin{array}{l}\text { Our department has a high level of } \\
\text { trust in local council. }\end{array}$ & (1) & (2) & (3) & (4) & (5) \\
\hline 12 & $\begin{array}{l}\text { Our department has a high level of } \\
\text { trust in community organization. }\end{array}$ & (1) & (2) & (3) & (4) & (5) \\
\hline 13 & $\begin{array}{l}\text { Our department has a high level of } \\
\text { trust in other departments. }\end{array}$ & (1) & (2) & (3) & (4) & (5) \\
\hline 14 & $\begin{array}{l}\text { Our department clearly and widely } \\
\text { understands the authority's missions, } \\
\text { values and objectives. }\end{array}$ & (1) & (2) & (3) & (4) & (5) \\
\hline 15 & $\begin{array}{l}\text { Our department thinks that the } \\
\text { missions and objectives are valuable. }\end{array}$ & (1) & (2) & (3) & (4) & (5) \\
\hline 16 & $\begin{array}{l}\text { The objectives of our department are } \\
\text { consistent and there is no conflict } \\
\text { with the objectives. }\end{array}$ & (1) & (2) & (3) & (4) & (5) \\
\hline 17 & $\begin{array}{l}\text { Our department concentrates on } \\
\text { achieving its missions, values and } \\
\text { objectives. }\end{array}$ & (1) & (2) & (3) & (4) & (5) \\
\hline
\end{tabular}

\section{SECTION 3: Organizational Performance}

Instruction: Each question is rated on a scale of 1 to 5, with 1 being strongly disagree and 5 being strongly agree. For each question please select the answer that best represents your response.

\begin{tabular}{|c|l|c|c|c|c|c|}
\hline No. & \multicolumn{1}{|c|}{ Question } & \multicolumn{5}{|c|}{ Scale } \\
\cline { 3 - 7 } & $\begin{array}{l}\text { strongly } \\
\text { disagree }\end{array}$ & disagree & neutral & agree & $\begin{array}{l}\text { strongly } \\
\text { agree }\end{array}$ \\
\hline 1 & $\begin{array}{l}\text { Time in handling the tasks of our } \\
\text { department is reduced. }\end{array}$ & $(1)$ & $(2)$ & (3) & (4) & (5) \\
\hline 2 & $\begin{array}{l}\text { Cost to dealing with tasks of our } \\
\text { department is reduced. }\end{array}$ & (1) & (2) & (3) & (4) & (5) \\
\hline
\end{tabular}




\begin{tabular}{|c|c|c|c|c|c|c|}
\hline 3 & $\begin{array}{l}\text { Accuracy of business process of our } \\
\text { department is improved. }\end{array}$ & (1) & (2) & (3) & (4) & (5) \\
\hline 4 & $\begin{array}{l}\text { Administrative efficiency of our } \\
\text { department is improved. }\end{array}$ & (1) & (2) & (3) & (4) & (5) \\
\hline 5 & $\begin{array}{l}\text { Planned goal of our department is } \\
\text { attained. }\end{array}$ & (1) & (2) & (3) & (4) & (5) \\
\hline 6 & $\begin{array}{l}\text { The quality of business process of } \\
\text { our department is improved. }\end{array}$ & (1) & (2) & (3) & (4) & (5) \\
\hline 7 & $\begin{array}{l}\text { Business productivity of our } \\
\text { department is improved. }\end{array}$ & (1) & (2) & (3) & (4) & (5) \\
\hline 8 & $\begin{array}{l}\text { Our department continually realizes } \\
\text { and promptly reacts the demands of } \\
\text { client (citizen). }\end{array}$ & (1) & (2) & (3) & (4) & (5) \\
\hline 9 & $\begin{array}{l}\text { Our department focuses on general } \\
\text { customer (citizen) satisfaction. }\end{array}$ & (1) & (2) & (3) & (4) & (5) \\
\hline 10 & $\begin{array}{l}\text { Our department understands the } \\
\text { demand of client and changes in } \\
\text { demand in a timely manner. }\end{array}$ & (1) & (2) & (3) & (4) & (5) \\
\hline 11 & $\begin{array}{l}\text { The distribution of resources (costs, } \\
\text { risks and benefits) resulting from } \\
\text { decision-making within our } \\
\text { department is fair with all staffs. }\end{array}$ & (1) & (2) & (3) & (4) & (5) \\
\hline 12 & $\begin{array}{l}\text { The process for determining the } \\
\text { resources within our department is } \\
\text { fair with all staffs. }\end{array}$ & (1) & (2) & (3) & (4) & (5) \\
\hline 13 & $\begin{array}{l}\text { Our department maintains fairness in } \\
\text { dealing with the human relationships } \\
\text { among staff. }\end{array}$ & (1) & (2) & (3) & (4) & (5) \\
\hline
\end{tabular}

\section{SECTION 4: Demographic Questions}

Instruction: The following questions will be used only to develop categories for analysis purposes. Your responses will be kept fully confidential. They will NOT be used to identify any individual, nor will they be shared with anyone else. In order to keep your identity confidential, we do not ask for your name or contact information.

1. How old are you? years

2. What is your gender? (1) male (2) female

3. How many years of full-time work experience have you had? years

4. How many years of public sector work experience have you had? years 
5. How long have you worked for your current employer/position? months

6. What is your educational level? (indicate highest level completed)
a. High school graduate
b. 2-year associate degree
c. College graduate
d. Master's degree
e. Doctorate degree (Ph.D., M.D., Ed.D., etc.)
f. Other (please specify):

7. What service area do you work in?
a. Public Works
b. Human Rights and Relations, Human Resources
c. Permits and Inspections, Urban Planning, Housing \& Community Development 
안녕하십니까?

공사 업무에 바쁘신데 불편을 드리게 되어 대단히 죄송합니다. 본 조사는 문화가 서로 다른 국가에서 사회자본이 조직성과에 어떠한 영향을 미치는가를 살펴보고자 하는데 목적이 있습니다. 선생님께서는 제시된 문항에 대해 선생님의 생각이나 사실을 있는 그대로 기술해 주시면 되겠습니다.

선생님의 응답은 통계자료 이외의 어떤 용도로도 사용되지 않으며, 본 연구를 위한 소중한 자료로만 익명으로 활용될 것입니다. 선생님의 도움에 깊이 감사드리며, 다음의 유의사항을 읽고 설문 조사지를 작성해 주시면 고맙겠습니다.

\section{$\star$ 유의사항}

1. 답변은 반드시 요구대로 해주시고, 해당 평가척도표에 $(\vee$ 나 $\bigcirc \mid$ 표시를 해주시기 바랍니다.

2. 한 문항에 표시를 하나만 기입해 주시기 바랍니다.

3. 반드시 모든 문항에 답해 주시기 바랍니다.

Florida International University Department of Public Administration

지도교수: Meredith Newman 조사자: 행정학과 박사과정 송정현 e-mail: jsong003@fiu.edu 


\section{설문문항}

\section{SECTION ।: 문화}

알림: 각 문항에 대한 척도는 | 점에서 5점의 척도로 구성되었습니다(I 은 매우 그렇지 않다, 5 는 매우 그렇다). 각 문항을 읽고 선생님의 의견을 척도표에서 선택해주십시오.

\begin{tabular}{|c|c|c|c|c|c|c|}
\hline \multirow[b]{2}{*}{ No } & \multirow[b]{2}{*}{ 문 항 } & \multicolumn{5}{|c|}{ 척도 } \\
\hline & & $\begin{array}{c}\text { 매우 } \\
\text { 아니다 }\end{array}$ & $\begin{array}{c}\text { 아니 } \\
\text { 다 }\end{array}$ & 보통 & 그렇다 & $\begin{array}{c}\text { 매우 } \\
\text { 그렇다 }\end{array}$ \\
\hline 1 & $\begin{array}{l}\text { 높은 지위에 있는 사람은 낮은 지위에 } \\
\text { 있는 사람과 상의 없이 대부분의 } \\
\text { 결정을 해야만 한다. }\end{array}$ & (1) & (2) & (3) & (4) & (5) \\
\hline 2 & $\begin{array}{l}\text { 높은 지위에 있는 사람은 낮은 지위에 } \\
\text { 있는 사람의 의견을 너무 자주 묻지 } \\
\text { 말아야 한다. }\end{array}$ & (1) & (2) & (3) & (4) & (5) \\
\hline 3 & $\begin{array}{l}\text { 높은 지위에 있는 사람은 낮은 지위에 } \\
\text { 있는 사람과 사회적 상호작용 (또는 } \\
\text { 꾜류) 을 피해야만 한다. }\end{array}$ & (1) & (2) & (3) & (4) & (5) \\
\hline 4 & $\begin{array}{l}\text { 낮은 지위에 있는 사람은 높은 지위에 } \\
\text { 있는 사람들의 결정에 반대하면 안 } \\
\text { 된다. }\end{array}$ & (1) & (2) & (3) & (4) & (5) \\
\hline 5 & $\begin{array}{l}\text { 높은 지위에 있는 사람은 낮은 지위에 } \\
\text { 있는 사람에게 중요한 업무 (또는 } \\
\text { 과제) 를 위임해서는 안 된다. }\end{array}$ & (1) & (2) & (3) & (4) & (5) \\
\hline 6 & $\begin{array}{l}\text { 훈령이나 지침서는 내가 무엇을 해야 } \\
\text { 하는지를 알 수 있게 해주기 때문에 } \\
\text { 중요하다. }\end{array}$ & (1) & (2) & (3) & (4) & (5) \\
\hline 7 & 지시와 절차를 따르는 것은 중요하다. & (1) & (2) & (3) & (4) & (5) \\
\hline 8 & $\begin{array}{l}\text { 규칙과 규정은 나에 대한 기대가 } \\
\text { 무엇인지를 알려주기 때문에 중요하다. }\end{array}$ & (1) & (2) & (3) & (4) & (5) \\
\hline 9 & 표준화된 업무 절차는 도움이 된다. & (1) & (2) & (3) & (4) & (5) \\
\hline 10 & $\begin{array}{l}\text { 업무지침서는 업무의 수행을 위해서 } \\
\text { 중요하다. }\end{array}$ & (1) & (2) & (3) & (4) & (5) \\
\hline 11 & $\begin{array}{l}\text { 개인은 집단을 위해 자신의 이익을 } \\
\text { 희생해야 한다. }\end{array}$ & (1) & (2) & (3) & (4) & (5) \\
\hline 12 & $\begin{array}{l}\text { 개인은 어려움이 있을지라도 집단이나 } \\
\text { 조직과 함께 해야 한다. }\end{array}$ & (1) & (2) & (3) & (4) & (5) \\
\hline
\end{tabular}




\begin{tabular}{|c|c|c|c|c|c|c|}
\hline \multirow[b]{2}{*}{ No } & \multirow[b]{2}{*}{ 문 항 } & \multicolumn{5}{|c|}{ 척도 } \\
\hline & & $\begin{array}{l}\text { 매우 } \\
\text { 아니다 }\end{array}$ & $\begin{array}{l}\text { 아니 } \\
\text { 다 }\end{array}$ & 보통 & 그렇다 & $\begin{array}{l}\text { 매우 } \\
\text { 그렇다 }\end{array}$ \\
\hline 13 & $\begin{array}{l}\text { 집단의 복지가 개인에 대한 보상보다 } \\
\text { 중요하다. }\end{array}$ & (1) & (2) & (3) & (4) & (5) \\
\hline 14 & $\begin{array}{l}\text { 집단의 성공이 개인의 성공보다 } \\
\text { 중 요하다. }\end{array}$ & (1) & (2) & (3) & (4) & (5) \\
\hline 15 & $\begin{array}{l}\text { 개인은 집단의 복지를 고려한 후에 } \\
\text { 목적을 추구해야 한다. }\end{array}$ & (1) & (2) & (3) & (4) & (5) \\
\hline 16 & $\begin{array}{l}\text { 개인의 목적에 방해가 될지라도 집단에 } \\
\text { 대한 충성심은 장려 되어야만 한다. }\end{array}$ & (1) & (2) & (3) & (4) & (5) \\
\hline 17 & $\begin{array}{l}\text { 절약을 위해서는 돈을 신중히 관리 } \\
\text { 하는 것이 중요하다. }\end{array}$ & (1) & (2) & (3) & (4) & (5) \\
\hline 18 & $\begin{array}{l}\text { 반대에도 불구하고 단호한 결단은 } \\
\text { 필요하다. }\end{array}$ & (1) & (2) & (3) & (4) & (5) \\
\hline 19 & 개인의 끈기와 안정은 중요하다. & (1) & (2) & (3) & (4) & (5) \\
\hline 20 & 장기계획이 단기계획보다 중요하다. & (1) & (2) & (3) & (4) & (5) \\
\hline 21 & $\begin{array}{l}\text { 미래의 성공을 위해서 현재의 쾌락이나 } \\
\text { 즐거움을 포기하는 것이 필요하다. }\end{array}$ & (1) & (2) & (3) & (4) & (5) \\
\hline 22 & $\begin{array}{l}\text { 미래의 성공을 위해서 열심히 일하는 } \\
\text { 것은 중 요하다. }\end{array}$ & (1) & (2) & (3) & (4) & (5) \\
\hline 23 & $\begin{array}{l}\text { 전문적 경력을 갖는 것은 여성보다 } \\
\text { 남성에게 중요하다. }\end{array}$ & (1) & (2) & (3) & (4) & (5) \\
\hline 24 & $\begin{array}{l}\text { 남성은 문제를 주로 논리적으로 } \\
\text { 해결한다; 이에 반해 여성은 주로 } \\
\text { 직관적으로 문제를 해결한다. }\end{array}$ & (1) & (2) & (3) & (4) & (5) \\
\hline 25 & $\begin{array}{l}\text { 어져운 문제를 해결하기 위해서는 주로 } \\
\text { 남성상을 대표하는 활동적이고 } \\
\text { 강제적인 접근방식이 요구된다. }\end{array}$ & (1) & (2) & (3) & (4) & (5) \\
\hline 26 & $\begin{array}{l}\text { 남성이 여성보다 항상 잘 할 수 있는 } \\
\text { 일들이 있다. }\end{array}$ & (1) & (2) & (3) & (4) & (5) \\
\hline
\end{tabular}




\section{SECTION 2: 사회자본}

알림: 각 문항은 | 점에서 5 점의 척도로 구성되었습니다(। 은 매우 그렇지 않다, 5 는 매우 그렇다). 각 문항을 읽고 선생님의 의견을 척도 표에서 선택해주십시오.

\begin{tabular}{|c|c|c|c|c|c|c|}
\hline \multirow[b]{2}{*}{ No } & \multirow[b]{2}{*}{ 문 항 } & \multicolumn{5}{|c|}{ 척도 } \\
\hline & & $\begin{array}{l}\text { 매우 } \\
\text { 아니다 }\end{array}$ & $\begin{array}{l}\text { 아니 } \\
\text { 다 }\end{array}$ & 보통 & $\begin{array}{l}\text { 그렇 } \\
\text { 다 }\end{array}$ & $\begin{array}{l}\text { 매우 } \\
\text { 그렇다 }\end{array}$ \\
\hline 1 & $\begin{array}{l}\text { 우리 부서는 내부적으로 업무조정이나 } \\
\text { 협업을 적극적으로 한다. }\end{array}$ & (1) & (2) & (3) & (4) & (5) \\
\hline 2 & $\begin{array}{l}\text { 우리 부서는 타 부서와 업무조정이나 } \\
\text { 협업을 적극적으로 한다. }\end{array}$ & (1) & (2) & (3) & (4) & (5) \\
\hline 3 & $\begin{array}{l}\text { 우리 부서는 타 부서와 다양한 연계 } \\
\text { 망(네트워크)과 정보를 공유하고 있다. }\end{array}$ & (1) & (2) & (3) & (4) & (5) \\
\hline 4 & $\begin{array}{l}\text { 우리 부서는 지역사회의 다양한 } \\
\text { 조직들과 밀접한 교류를 맺고 있다. }\end{array}$ & (1) & (2) & (3) & (4) & (5) \\
\hline 5 & $\begin{array}{l}\text { 우리 부서는 자치단체장과 돈독한 } \\
\text { 신뢰관계가 형성되어 있다. }\end{array}$ & (1) & (2) & (3) & (4) & (5) \\
\hline 6 & $\begin{array}{l}\text { 우리 부서는 상급자와 하급자 간에 높은 } \\
\text { 신뢰관계가 형성되어 있다. }\end{array}$ & (1) & (2) & (3) & (4) & (5) \\
\hline 7 & $\begin{array}{l}\text { 우리 부서는 동료들 간에 좋은 } \\
\text { 신뢰관계가 형성되어 있다. }\end{array}$ & (1) & (2) & (3) & (4) & (5) \\
\hline 8 & $\begin{array}{l}\text { 우리 부서는 지방의회의원을 매우 } \\
\text { 신뢰하고 있다. }\end{array}$ & (1) & (2) & (3) & (4) & (5) \\
\hline 9 & $\begin{array}{l}\text { 우리 부서는 주민과 좋은 신뢰관계를 } \\
\text { 구축하고 있다. }\end{array}$ & (1) & (2) & (3) & (4) & (5) \\
\hline 10 & $\begin{array}{l}\text { 우리 부서는 공무원노동조합을 매우 } \\
\text { 신뢰하고 있다. }\end{array}$ & (1) & (2) & (3) & (4) & (5) \\
\hline 11 & $\begin{array}{l}\text { 우리 부서는 지방의회를 매우 신뢰하고 } \\
\text { 있다. }\end{array}$ & (1) & (2) & (3) & (4) & (5) \\
\hline 12 & $\begin{array}{l}\text { 우리 부서는 이해관계가 있는 } \\
\text { 주민조직들과 신뢰가 잘 구축되어 있다. }\end{array}$ & (1) & (2) & (3) & (4) & (5) \\
\hline 13 & $\begin{array}{l}\text { 우리 부서는 타 부서와 좋은 신뢰관계가 } \\
\text { 형성되어 있다. }\end{array}$ & (1) & (2) & (3) & (4) & (5) \\
\hline 14 & $\begin{array}{l}\text { 우리 부서는 부서의 임무, 가치 그리고 } \\
\text { 목표를 정확히 이해하고 있다. }\end{array}$ & (1) & (2) & (3) & (4) & (5) \\
\hline 15 & $\begin{array}{l}\text { 우리 부서는 부서의 목표가 가치 있다고 } \\
\text { 생각한다. }\end{array}$ & (1) & (2) & (3) & (4) & (5) \\
\hline 16 & $\begin{array}{l}\text { 우리 부서는 부서의 목표가 일치하여 } \\
\text { 갈등이 발생하지는 않는다. }\end{array}$ & (1) & (2) & (3) & (4) & (5) \\
\hline 17 & $\begin{array}{l}\text { 우리 부서는 부서의 목표나 가치를 } \\
\text { 달성하기 위해 최선을 다하고 있다. }\end{array}$ & (1) & (2) & (3) & (4) & (5) \\
\hline
\end{tabular}




\section{SECTION 3: 조직성과}

알림: 각 문항은 | 점에서 5 점의 척도로 구성되었습니다(। 은 매우 그렇지 않다, 5 는 매우 그렇다), 각 문항을 읽고 선생님의 의견을 척도표에서 선택해주십시오.

\begin{tabular}{|c|c|c|c|c|c|c|}
\hline \multirow[b]{2}{*}{ No } & \multirow[b]{2}{*}{ 문 항 } & \multicolumn{5}{|c|}{ 척도 } \\
\hline & & $\begin{array}{l}\text { 매우 } \\
\text { 아니다 }\end{array}$ & 아니다 & 보통 & $\begin{array}{l}\text { 그렇ㅎㅎ } \\
\text { 다 }\end{array}$ & $\begin{array}{l}\text { 매우 } \\
\text { 그렇다 }\end{array}$ \\
\hline 1 & $\begin{array}{l}\text { 우리 부서는 업무를 처리하는데 } \\
\text { 소요되는 시간을 감축하였다. }\end{array}$ & (1) & (2) & (3) & (4) & (5) \\
\hline 2 & $\begin{array}{l}\text { 우리 부서는 업무를 처리하는데 } \\
\text { 소요되는 비용을 절감하였다. }\end{array}$ & (1) & (2) & (3) & (4) & (5) \\
\hline 3 & $\begin{array}{l}\text { 우리 부서는 업무를 처리하는데 } \\
\text { 정확도를 높였다. }\end{array}$ & (1) & (2) & (3) & (4) & (5) \\
\hline 4 & $\begin{array}{l}\text { 우리 부서는 업무를 처리하는데 } \\
\text { 효율성을 증진시켰다. }\end{array}$ & (1) & (2) & (3) & (4) & (5) \\
\hline 5 & $\begin{array}{l}\text { 우리 부서는 이전에 계획했던 목표를 } \\
\text { 달성하였다. }\end{array}$ & (1) & (2) & (3) & (4) & (5) \\
\hline 6 & $\begin{array}{l}\text { 우리 부서가 처리하는 업무 과정의 질이 } \\
\text { 개선되었다. }\end{array}$ & (1) & (2) & (3) & (4) & (5) \\
\hline 7 & $\begin{array}{l}\text { 우리 부서가 처리하는 업무의 생산성이 } \\
\text { 높아졌다. }\end{array}$ & (1) & (2) & (3) & (4) & (5) \\
\hline 8 & $\begin{array}{l}\text { 우리 부서는 주민의 요구를 지속적으로 } \\
\text { 파악하고 신속하게 대응하고 있다. }\end{array}$ & (1) & (2) & (3) & (4) & (5) \\
\hline 9 & $\begin{array}{l}\text { 우리 부서는 주민을 만족시키는데 } \\
\text { 업무의 초점을 두고 있다. }\end{array}$ & (1) & (2) & (3) & (4) & (5) \\
\hline 10 & $\begin{array}{l}\text { 우리 부서는 주민의 요구와 수요의 } \\
\text { 변화를 시의 적절하게 파악하고 있다. }\end{array}$ & (1) & (2) & (3) & (4) & (5) \\
\hline 11 & $\begin{array}{l}\text { 우리 부서는 구성원들에게 자원(비용, } \\
\text { 위험, 이익) 을 공정하게 분배하고 있다. }\end{array}$ & (1) & (2) & (3) & (4) & (5) \\
\hline 12 & $\begin{array}{l}\text { 우리 부서는 자원을 배분하는 과정에서 } \\
\text { 구성원들을 공정하게 대하고 있다. }\end{array}$ & (1) & (2) & (3) & (4) & (5) \\
\hline 13 & $\begin{array}{l}\text { 우리 부서는 공정한 인간관계를 } \\
\text { 추구하고 있다. }\end{array}$ & (1) & (2) & (3) & (4) & (5) \\
\hline
\end{tabular}




\section{SECTION 4: 이반ㄴ 문항}

알림: 다음의 문항들은 선생님에 대한 개괄적인 질문 문항들입니다. 기입해 주시기를 부탁 드립니다.

I. 선생님의 연령은? 세

2. 선생님의 성별은?
(1) 남자 ( )
(2) 여자 ( )

3. 선생님의 근무 경력(사회 경력 포함) 은? 년

4. 선생님께서 공무원으로 근무하신 경력은? 년

5. 선생님께서 현재 부서에서 근무 한지는 얼마나 되셨습니까? 년

6. 선생님의 교육수 준은? (가장 높은 것을 선택해주세요)
(1) 고졸
(2) 전문대 졸 ( )
(3) 대졸 ( )
(4) 석사학위 ( )
(5) 박사학위 ( )
(6) 기타

7. 선생님께서 근무하고 계신 부서는 다음 중 어디에 속하십니까?
(1) 건강체육과, 공원녹지과, 정보통신과, 산림과 ( )
(2) 복지정책과, 생활보장과, 여성가족과
(3) 교통행정과, 건축과, 건설방재과 


\title{
JUNG HYUN SONG
}

\author{
$1999-2001$ \\ B. A., Public Administration \\ Sangji University, South Korea \\ $2002-2004$ \\ M. A., Public Administration \\ Sangji University, South Korea \\ $2003-2005$ \\ Administrative Assistant, Department of Public \\ Administration \\ Sangji University, South Korea \\ $2008-2010$ \\ M.P.P., Public Policy \\ Oregon State University \\ Corvallis, Oregon \\ $2010-2016$ \\ Doctoral Candidate, Public Affairs \\ Florida International University \\ Miami, Florida
}

\section{PUBLICATIONS AND CONFERENCE PRESENTATIONS}

Kim, T. R., Kim, J. S., \& Song, J. H. (2009). The Effect of the Information Inequality on the Formation of Social Capital. Korea Local Government Review. 11 (3).

Song, J. H., \& Kim, T. R. “An Empirical Study on the Relationship between Organizational Structure and Social Capital". Accepted at the Korean Association for Public Administration Summer Conference, Sangmyung University Cheonan Campus, South Korea, July 16-18, 2015. 
Song, J. H., An, H. J., \& Kim, T. R. "Relevance of Social Capital Theory: Centering around Research Trends" Presented at the Annual Conference for Public Administration, American Society for Public Administration, Chicago, Illinois, March 6-10, 2015.

Song, J. H. "The Effects of Social Capital on Organizational Performance in Local Government Organization.” International Young Scholars Workshop, Jilin University, China, July 21-24, 2014.

Song, J. H., An, H. J., \& Kim, T. R. "Research Trend Analysis of Social Capital.” Presented at the World Conference for Public Administration, Korean Association for Public Administration, Daegu, South Korea, June 25-27, 2014.

Song, J. H. "Does Network Capital Improve Community Sustainability? A Case of Community Water Supply Projects in Nepal." Discussant at the ASPA Conference Panel: Environment and Water Policy, Washington, D.C. March 14-18, 2014.

Song, J. H. "Municipal Sustainability Plans, Programs, and Polices in Oregon Cities." Presented at the Korean Association for Public Administration Summer Conference, Korea University Seajong Campus, South Korea, June 28, 2013.

Song, J. H. "A Study on the Factors Affecting Environmental Policy Adoption.” SECoPA Conference, Coral Springs, Florida, October 3-6, 2012. 